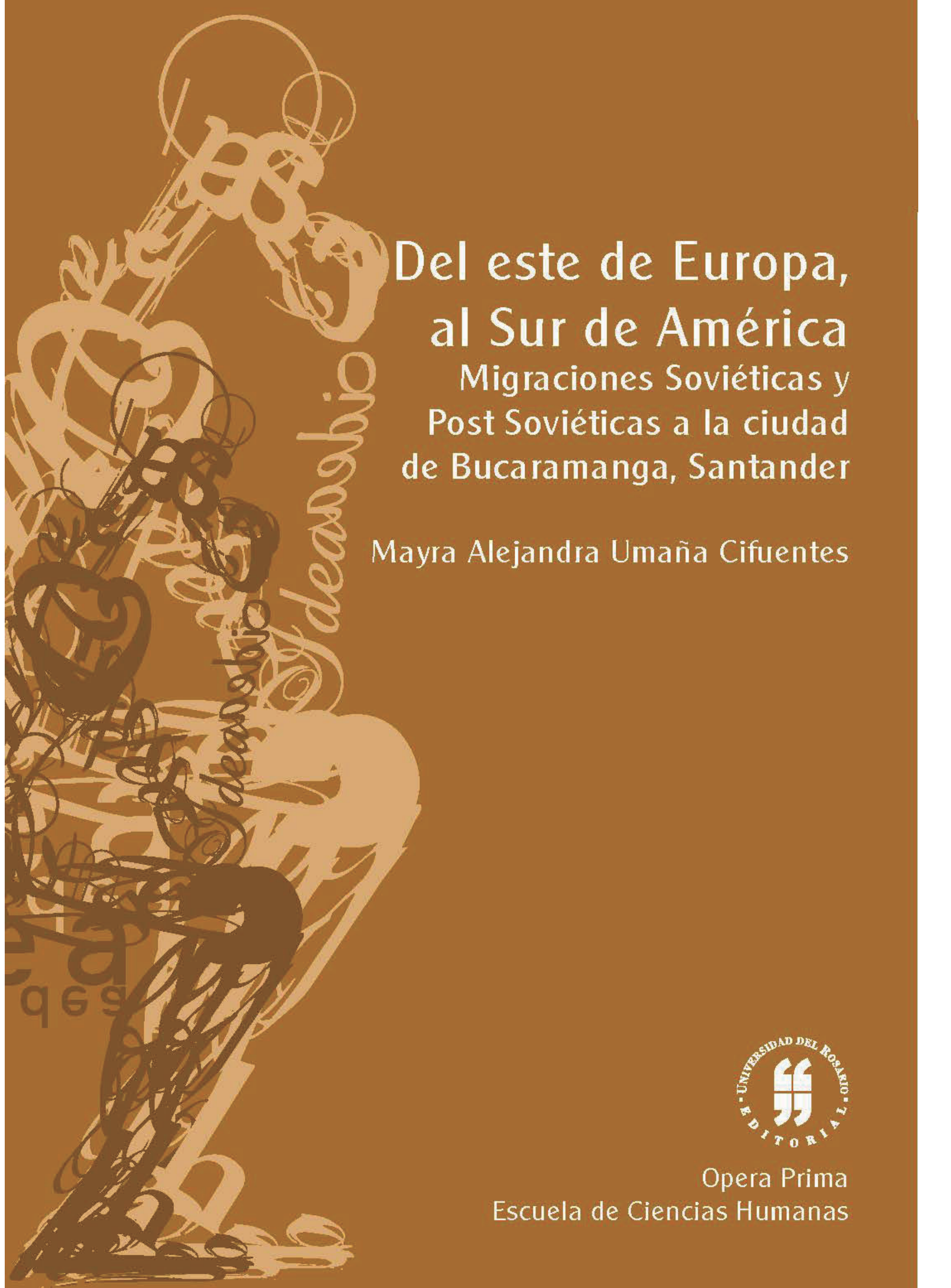



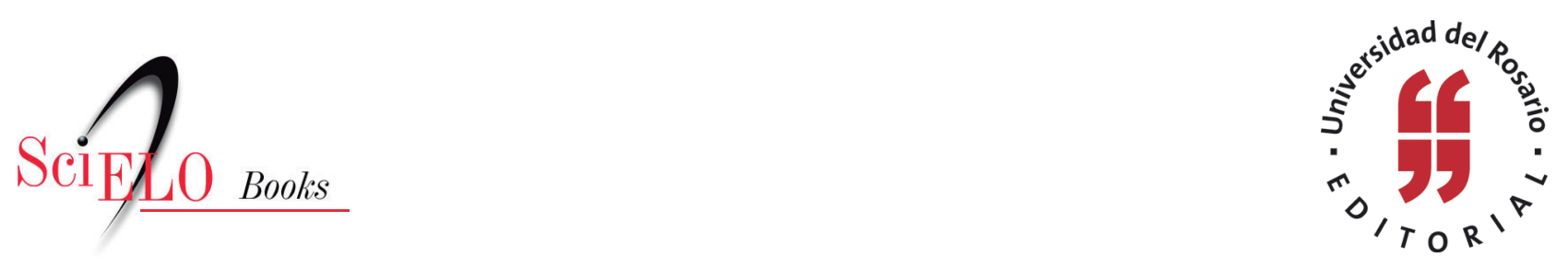

\title{
Del este de Europa al sur de América migraciones soviéticas y postsoviéticas a la ciudad de Bucaramanga, Santander
}

\author{
Mayra Alejandra Umaña Cifuentes
}

UMAÑA CIFUENTES, M.A. Del este de Europa al sur de América: Migraciones soviéticas y postsoviéticas a la ciudad de Bucaramanga, Santander [online]. Bogotá: Editorial Universidad del Rosario, 2015, 233 p. Opera prima collection. ISBN: 978-958-738-595-3.

https://doi.org/10.7476/9789587385953.

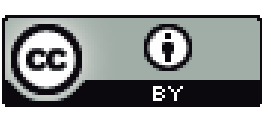

All the contents of this work, except where otherwise noted, is licensed under a Creative Commons Attribution 4.0 $\underline{\text { International license. }}$

Todo o conteúdo deste trabalho, exceto quando houver ressalva, é publicado sob a licença Creative Commons Atribição $\underline{4.0}$.

Todo el contenido de esta obra, excepto donde se indique lo contrario, está bajo licencia de la licencia Creative Commons Reconocimento 4.0. 
UR 



\section{DEL ESTE DE EUROPA AL SUR DE AMÉRICA}

Migraciones soviéticas y postsoviéticas a la ciudad de Bucaramanga, Santander 
Umaña Cifuentes, Mayra Alejandra

Del este de Europa al sur de América: Migraciones soviéticas y postsoviéticas a la ciudad de Bucaramanga, Santander / Mayra Alejandra Umaña Cifuentes. - Bogotá: Editorial Universidad del Rosario, Escuela de ciencias Humanas, 2015.

233 páginas. - (Colección Opera Prima)

Incluye referencias bibliográficas.

ISBN: 978-958-738-594-6 (rústica)

ISBN: 978-958-738-595-3 (digital)

Europa - Historia / Emigración e inmigración - Europa / Emigración e inmigración - América Latina / Geopolítica / Multiculturalidad / Bucaramanga (Santander, Colombia) - Vida social y costumbres / Colombia - Relaciones exteriores - Unión de Repúblicas Socialistas Soviéticas / I. Título / II. Serie.

304.82 SCDD 20

Catalogación en la fuente - Universidad del Rosario. Biblioteca

amv

Marzo 4 de 2015

Hecho el depósito legal que marca el Decreto 460 de 1995 


\section{DEL ESTE DE EUROPA AL SUR DE AMÉRICA Migraciones soviéticas y postsoviéticas a la ciudad de Bucaramanga, Santander}

MAYRA ALEJANDRA UMAÑA CIFUENTES 


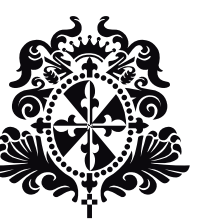

Colección Opera Prima

(C) Editorial Universidad del Rosario

(C) Universidad del Rosario

Escuela de Ciencias Humanas

(C) Mayra Alejandra Umaña Cifuentes

Editorial Universidad del Rosario

Carrera 7 No 12B-41, oficina 501

Teléfono 2970200

http://editorial.urosario.edu.co

Primera edición: Bogotá D.C., abril de 2015

ISBN: 978-958-738-594-6 (rústica)

ISBN: 978-958-738-595-3 (digital)

Coordinación editorial:

Editorial Universidad del Rosario

Corrección de estilo: Manuel Gómez

Diseño de cubierta y diagramación:

Precolombi EU-David Reyes

Impresión:

Impreso y hecho en Colombia

Printed and made in Colombia

Fecha de evaluación: 12 de marzo de 2013

Fecha de aceptación: 22 de septiembre de 2014

Todos los derechos reservados. Esta obra no puede ser reproducida sin el permiso previo por escrito de la Editorial Universidad del Rosario. 


\section{Contenido}

Agradecimientos ............................................................................ 11

Introducción ........................................................................ 13

Preguntas de investigación e hipótesis ............................... 17

Metodología ....................................................................................... 21

1. Capítulo I. Dos historias paralelas................................ 27

1.1. Latinoamérica: una mirada general

a las inmigraciones................................................ 27

1.2. El sueño que no se hizo realidad: el inmigrante ideal y los debates políticos en Colombia............ 29

1.3. ¿Y qué paso en realidad? Los inmigrantes que llegaron a Colombia......................................... 35

1.4. Las migraciones y el desarrollo de un departamento: los extranjeros en Santander ........ $\quad 40$

1.5. Del Imperio ruso a la perestroika: las migraciones en la Unión Soviética .................... 47 1.5.1. Geopolítica y multiculturalidad del Imperio ruso y la Unión Soviética ...... 48

1.5.2. La migración en la Unión Soviética .......... 50

1.5.3. La urbanización ............................................ 51

1.5.4. Las migraciones desde el punto de vista étnico................................................ 52 
1.6. Las migraciones durante la perestroika y la posperestroika ................................................. 54

1.6.1. Repatriación y conflicto étnico ................. 54

1.6.2. La migración postsoviética hacia el resto del mundo ...................................... 56

2. Capítulo II. "Nunca imaginé vivir en Colombia”... 59

2.1. ¿Por qué salimos? El contexto expulsor .............. 59

2.1.1. Contexto expulsor push ............................ 59

2.2. ¿Por qué a Colombia?........................................... 82

2.2.1. El capital social y las redes como elementos de atracción ................................. 83

2.2.2. Los lazos débiles y su importancia en el proceso migratorio ............................. 87

2.2.3. La reunificación familiar ............................. 91

2.2.4. Los lazos fuertes y su importancia en el proceso migratorio ............................ 92

2.2.5. El capital cultural y la inserción laboral ... 97

2.2.6. El papel de las instituciones

y los convenios internacionales

en el proceso migratorio

2.3. "Nunca imaginé que fuera a vivir

en Colombia”. Imaginarios sobre el destino ....... 110

\section{Capítulo III. "Yo soy un ruso con sabor} colombiano".

3.1. Socialización e integración en Bucaramanga ....... 121

3.1.1. "Uno está como un niño perdido" ........... 127

3.1.2. El papel de los vínculos durante los primeros días 
3.1.3. El lenguaje y la socialización .................... 137

3.1.4. Del socialismo al capitalismo..................... 139

3.2. Aprendiendo a ser colombiano: Integración, socialización y capital cultural ............................ 143

3.3. Paisanos y nativos como agentes de socialización .................................................. 149

3.3.1. ¿Existe una comunidad soviética?............. 157

3.3.2. El camino a la asimilación........................... 163

3.4. "Yo soy un ruso con sabor colombiano":

construcción de identidad de los migrantes

soviéticos ................................................................ 169

3.5. "Yo chupé teta de madre ucraniana":

identidad soviética ............................................... 177

3.5.1. Hacia una identidad soviética................... 177

3.5.2. La importancia de los otros en la construcción de la identidad....................... 180

3.5.3. Socialización e identidad: dos procesos simultáneos.................................................... 185

3.5.4. "Nunca dejarás de ser de allí, tu pasaporte te lo recuerda"

3.5.5. Hacia una identidad colombiana............... 192

3.5.6. "Ya tengo cédula, soy colombiano": identidad colombiana

3.5.7. "Yo soy un ruso con sabor colombiano": manutención de identidades y sincretismos ......................... 206

4. Conclusiones ........................................................................ 215

5. Referencias................................................................... 225 



\section{Agradecimientos}

La realización y publicación de este trabajo de investigación no habría sido posible sin el apoyo absoluto e incondicional de mis padres, Gerardo Umaña Uribe y Lucy Cifuentes Porras, a quienes agradezco su acompañamiento en todo este proceso, y a quienes dedico esta publicación.

Agradezco muy especialmente a Anne Gincel Collazos por su apoyo, comentarios, seguimiento, guía e instrucción en la realización de esta investigación, que gracias a su ayuda llegó a ser merecedora del Premio Otto de Greiff en el área de Ciencias Sociales. A William Mejía Ochoa y Juan Thomas Ordoñez por la lectura juiciosa de este documento y su valiosa retroalimentación. Adicionalmente, agradezco a Julián Andrés Riveros Clavijo, por su ayuda en el trabajo de campo, por sus aportes y comentarios, que sin duda enriquecieron este análisis. Asimismo, agradezco a Mauricio Flórez-Morris por su sincera ayuda, ánimo y comentarios durante el proceso.

Expreso mi gratitud particularmente a todas las personas que contribuyeron con sus relatos a la realización de este trabajo, a quienes agradezco su tiempo y amabilidad durante la fase de campo. 



\section{Introducción}

Las imágenes de enormes barcos de vapor transatlánticos, que venían desde lados remotos de ultramar para atracar en el puesto de inmigración de la isla Ellis, que funcionó de 1892 a 1954, en los Estados Unidos, desembarcando grandes masas de personas que se trasladaban hacia las grandes ciudades industriales, son las que evocan los estudios de inmigración que, en cabeza de Park, la escuela de Chicago desarrolló iniciando el siglo xx.

Dentro de los inmigrantes que llegaron en ese periodo a los Estados Unidos, hubo un grupo particular de gente proveniente del entonces Imperio ruso, se trató de los molokanos. Esta fue la primera comunidad, proveniente del este de Europa, en ser estudiada. Los molokanos fueron descritos en 1929 por Pauline V. Young como una "comunidad que por un cuarto de siglo había luchado incesantemente para mantener su forma de vida comunal y organización cultural nativa peculiar, que dejaron su tierra natal en grandes grupos familiares o clanes, en un volumen de más o menos unos 7000 individuos". ${ }^{1}$

1 Young anotaba también que su nombre, Molo-Kanos, había sido otorgado por la Iglesia ortodoxa, porque este grupo religioso disidente no se abstenía de beber leche durante la cuaresma. Molokanos significa "bebedores de leche”. 
Fueron caracterizados por su tendencia al aislamiento social, sus costumbres fuertemente marcadas por una tradición religiosa disidente y por su dedicación a las labores agrícolas. Adicionalmente fueron caracterizados como personas que rechazaban la educación por considerar que el conocimiento del mundo solo podría provenir de Dios, que ocupaban posiciones sociales bajas y mantenían fuertes vínculos comunales.

Recapitulando, los molokanos fueron una secta disidente del cristianismo ortodoxo ruso, que emigró desde la región transcaucásica del entonces Imperio ruso, por las persecuciones eclesiásticas, para residir en la ciudad de Los Angeles, en el estado de California. Los primeros casos documentados de inmigrantes provenientes del entonces Imperio ruso fueron los de los molokanos y de los denominados Jumpers, una secta de similares características, también estudiada por Young. Por esta razón, el artículo intitulado "The Russian Molokan Community in Los Angeles" es un hito en el estudio de las migraciones de las regiones eslavas. Sin embargo, es poco lo que queda del retrato que para 1929 dibujó Young. La migración a la cual nosotros nos referiremos en esta investigación se enmarca en un contexto completamente diferente. Se produjo a finales del siglo xx, coincidiendo con la perestroika y la caída de la Unión de Repúblicas Socialistas Soviéticas, unidad política que no existía siquiera cuando los molokanos llegaron a América.

Young, Pauline. "The Russian Molokan Community in Los Angeles". American Journal of Sociology 35 (1929): 393-402. Impreso. 
Muy por el contrario del esbozo de Young, las personas que hacen parte de este nuevo flujo migratorio que se asentó en Bucaramanga, son altamente capacitadas y educadas, no migraron en comunidad, sino de manera individual o en grupos familiares pequeños, y han llegado a ocupar posiciones sociales sobresalientes, integrándose de manera relativamente exitosa.

En la actualidad, son los directores de centros de investigación en la ciudad de Bucaramanga, en áreas como la química biomolecular, la física y las matemáticas. Han aportado al desarrollo científico de la región ${ }^{2}$ y, en el campo de la música, han pertenecido a bandas locales. Han producido innumerables artículos académicos, libros, ponencias y productos tecnológicos. Además de aportar al campo de la literatura, la historia, la pintura y la lingüística, posicionándose en la región como agentes de progreso y desarrollo.

A pesar de la notoria influencia de estos sujetos en la región, no es mucho lo que se sabe de ellos, pues el único esfuerzo nacional por caracterizar la población de inmigrantes en Colombia se reduce a los censos del Departamento Administrativo Nacional de Estadística (DANE), los cuales sólo aportan información sobre las tres inmigraciones más grandes que en este momento se encuentran en el país: la venezolana, la estadounidense y la ecuatoriana, agrupando

2 Son estos inmigrantes, además, los que han ganado premios a nivel nacional y regional como el Premio de Colciencias dentro de los 50 mejores investigadores del país y el Premio Nacional al Mérito Científico, de la Asociación Colombiana para el Avance de la Ciencia, en el 2001, en la categoría Investigador de Excelencia, entre otros. 
a los inmigrantes de otros países en la categoría otros. Estos otros inmigrantes, que en el censo del 2005 llegaron a ser el $38 \%$, no son exhaustivamente caracterizados, dejando abiertas gran variedad de interrogantes con respecto a su procedencia, sus procesos migratorios y su adaptación en la sociedad receptora. ${ }^{3}$

3 Cifras tomadas de Cárdenas Mauricio y Carolina Mejía. "Migraciones internacionales en Colombia: ¿Qué sabemos?”. Working Papers Series 30 (2006): 27-30. Impreso. 


\section{Preguntas de investigación e hipótesis}

En esta investigación daremos respuesta a dos preguntas fundamentales que nos permitirán entender de manera profunda el proceso migratorio de los ciudadanos de las ex repúblicas soviéticas y serán la guía que estructurará este documento. La primera pregunta que nos compete es: ¿cuáles fueron los factores que motivaron la migración de ciudadanos provenientes de las naciones soviéticas y postsoviéticas a Colombia y Bucaramanga? En segunda medida, nos interesa indagar por cómo estos inmigrantes se integraron a la ciudad una vez se establecieron. Igualmente, hemos establecido como nuestra hipótesis principal la siguiente: el capital humano e intelectual que detentaban estos sujetos al llegar les permitirían integrarse a las élites intelectuales de la ciudad de Bucaramanga. Además, la alta cualificación de estos sujetos les permitiría una integración menos traumática y en esferas altas de la sociedad receptora, sin pasar por procesos de marginación.

Antes de proseguir, tenemos que enfatizar el hecho que es necesario superar: la falsa creencia de que en Colombia no existe la inmigración ni los inmigrantes, por el hecho de que no sucediera a gran escala, como sí sucedió en Estados Unidos y en países de la región como Brasil o Argentina. Este preconcepto se evidencia de dos formas: primero, en el 
hecho de que la producción académica suela centrarse en las personas que dejan el país y no en quienes llegan, y segundo, en el hecho de que la literatura académica sobre el tema obedezca más a investigaciones de tipo histórico, enfocadas en la caracterización de migraciones más antiguas y de mayor volumen, como la migración alemana a Santander y la sirio libanesa en el Caribe.

Por otra parte, las investigaciones sobre inmigraciones actuales se concentran en los grupos más notorios como los venezolanos y ecuatorianos. En este mismo sentido, los análisis no van más allá de la caracterización de la población, dejando de lado en el mundo académico grupos más pequeños, que aunque menores en cantidad, también hacen parte importante de las dinámicas migratorias y del desarrollo de las regiones.

La migración a la que aquí nos referimos hace parte de estos pequeños grupos que han llegado al país en las últimas décadas. Por tanto, la pretensión de este estudio es visibilizar esta población, además de descubrir cómo fueron sus procesos migratorios y describir cómo ha sido el proceso de integración a la ciudad receptora, a decir Bucaramanga. $\mathrm{Al}$ ser poca la información que se presenta sobre este grupo de inmigrantes en nuestro país, vale la pena explorar varios asuntos relacionados con sus procesos migratorios y de integración en la ciudad, con el fin de presentar un panorama amplio de los procesos migratorios de este grupo y sentar las bases para estudios ulteriores.

Suele afirmarse que no existe una teoría unificada sobre la migración. En este estudio asumimos esa misma postura. 
Además, veremos el proceso migratorio como un continuum temporal que inicia antes del hecho mismo de migrar y no concluye con el asentamiento de las personas, por lo cual utilizaremos no una teoría, sino una serie de teorías que nos ayuden a interpretar las diversas etapas del proceso. De la misma manera, el trabajo que presentamos aquí trata de seguir el proceso mismo que tuvieron los inmigrantes y se estructura de esa forma, por tanto este escrito se compone de tres capítulos, que a seguir desglosaremos.

El primer capítulo se divide en dos partes. En la primera, nos concentraremos en explicar la historia migratoria de Colombia y su ubicación dentro del panorama latinoamericano para después concentrarnos en explicar la inmigración que tuvo específicamente el departamento de Santander. Esto, con el fin de exponer la importancia que han tenido los inmigrantes en el desarrollo de la región y el lugar que han ocupado en el espacio social. En la segunda parte, nos enfocaremos en explicar la historia migratoria de la Unión de Repúblicas Socialistas Soviéticas -URss- con el fin de entender cómo y cuáles han sido las migraciones a través de su historia y especialmente en el periodo de la perestroika y la posperestroika.

En el segundo capítulo, nos concentraremos en indagar cuáles son los factores que influyen en la determinación del sujeto de desplazarse, indagando las causas de la migración en diferentes niveles, observando no sólo los factores macroestructurales, sino el papel de las redes en el proceso de la migración, así como la construcción de imaginarios, inquiriendo por el papel que jugaron en el proceso migratorio. 
En el tercer y último capítulo analizaremos el proceso de integración y asimilación a la ciudad de Bucaramanga, examinando el papel que juegan las relaciones con otros sujetos en el proceso de socialización, al igual que el papel de las instituciones. Encerraremos este capítulo analizando cómo debido a toda su experiencia migratoria y a sus procesos de integración, los inmigrantes han formado un vínculo identitario con el país y con la ciudad que coexiste con su modo de ser soviético. Para finalizar, debemos mencionar que, ante todo, en esta investigación pretendemos dar voz a quienes vivieron el proceso migratorio, rescatando sus historias, particularidades, subjetividades y perspectivas. 


\section{Metodología}

El trabajo de campo fue realizado durante los meses de febrero a septiembre del año 2010 en la ciudad de Bucaramanga. Se trató principalmente de una serie de entrevistas en profundidad con varios inmigrantes, en las cuales específicamente inquirimos por sus cursos de vida en relación con la migración, y de una serie de observaciones que hicimos en sus viviendas y lugares de trabajo.

El uso de historias de curso de vida en la investigación sobre migraciones ya ha sido probado y se justifica por tres razones: la primera de ellas, relacionada con lo que expone Howard Becker, explica que el uso de historias de vida permite aproximarnos a cuestiones subjetivas de los investigados, como sus experiencias, sus motivaciones y la interpretación que estos tienen de su realidad, cuestiones que sólo pueden ser entendidas desde el punto de vista de quien vivió una experiencia y que, de no ser así, se podría incurrir en suposiciones y conjeturas. ${ }^{1}$

1 Becker, Howard. Historias de Vida en Sociología, citado en Balán, Jorge. Las Historias de Vida en Ciencias Sociales: Teoría y Técnica. Buenos Aires: Editorial Nueva Visión, 1974. 27-30. Impreso. 
En segundo lugar, esta metodología nos permitió explorar tanto lo subjetivo, individual, como lo estructural, ${ }^{2}$ lo cual es esencial para esta investigación, pues, aunque las experiencias migratorias sean individuales y las decisiones de hacerlo personales o familiares, los factores que las motivan pueden ser tanto del orden estructural, como crisis económicas o políticas de los países emisores, como de tipo individual, como la búsqueda de un mejor estatus. En tercer lugar está la posibilidad que nos brindó esta metodología de conferirle significado a la noción de proceso, ${ }^{3}$ pues aquí se está estudiando no solo un evento en la vida del sujeto sino un proceso que este experimenta, desde el momento antes de migrar hasta su establecimiento e integración en el país receptor.

Adicionalmente, la observación fue entendida como el método por el cual los investigadores sincrónica y sistemáticamente observan la realidad mientras participan de ella, dando relevancia al contexto en el que se produce información y conocimiento sobre los grupos y la cultura. ${ }^{4}$ La información proveniente de la observación fue recogida mediante el uso de un diario de campo, así como del registro visual

2 Resendiz, Ramón. "Biografía: proceso y nudos teórico-metodológicos". Observar, escuchary comprender. Sobre la tradición cualitativa en la investigación social. Ed. María Luisa Tarrés. México, Flacso, 2001: 135-170. Impreso. Historias".

3 Howard Becker, Historias de Vida en Sociología, en Balán, Jorge. “Las

4 Marsvati, Amir. Qualitative Research in Sociology: An Introduction. Gran Bretaña: SAGE, 2004. Impreso. 
hecho fotográficamente. ${ }^{5}$ Las observaciones nos permitieron dar una mirada más cercana y profunda a sus cotidianidades, particularmente nos permitieron observar los sincretismos entre las culturas soviéticas y colombiana, evidenciados en algunos comportamientos y actitudes. Aunque fue muy útil, fue sólo complementaria por el hecho de que no era posible siempre tener acceso fácil a la mayoría de los espacios en los que estas personas solían desenvolverse, ni participar de las actividades que ellos realizaban.

Por tanto, en la mayor parte de los casos la observación se realizó en lugares públicos donde los inmigrantes desarrollaban sus actividades laborales, principalmente las universidades, particularmente en dos dentro de la ciudad, que por protección y privacidad de los entrevistados no serán especificadas. También observamos eventos culturales como recitales de piano, conciertos de música popular y exposiciones de arte, en los cuales varios migrantes de Rusia y Ucrania suelen participar. Solamente cinco personas nos permitieron entrar a sus hogares.

La recolección de los cursos de vida se hizo con individuos nacidos en Rusia y Ucrania, los cuales migraron a Colombia y actualmente viven y se han establecido en la ciudad de Bucaramanga. Con la palabra "establecerse" hacemos referencia puntual al hecho de trabajar, tener su vivienda $\mathrm{y}$ redes sociales en esta ciudad. Solamente entrevistamos y observamos inmigrantes de primera generación, ya que el

5 Banks, Markus. Visual Methods in Social Research. Gran Bretaña: SAGE, 2001. Impreso. 
propósito de este trabajo así lo exigía, porque fueron ellos quienes tomaron la decisión de migrar y quienes vivieron este proceso de movilización. El rango de edad fue amplio, pues lo que nos interesaba era el hecho de que hubiesen migrado y no su clasificación en un grupo etario, aunque de facto, en el análisis veremos que es posible hacer una gradación por edad.

Los 15 sujetos que participaron en este estudio aportando sus historias de vida, colaborándonos con entrevistas, fueron encontrados mediante el procedimiento de bola de nieve. En total iniciamos tres bolas diferentes por diferentes redes con el fin de ampliar la variabilidad de la muestra. Creemos que este fue el método más pertinente en este caso porque no existía una base de datos confiable de los habitantes de las ex repúblicas soviéticas que han migrado, ni en organismos nacionales como el Departamento Administrativo de Seguridad (DAS), ni en internacionales, como la Embajada de Rusia en Colombia.

La idea en principio de esta investigación era trabajar con ciudadanos rusos residentes en la ciudad de Bucaramanga. Sin embargo, al implementar la bola de nieve y buscar las personas para este estudio, nos encontramos con que personas que eran conocidas coloquialmente como "rusos", en realidad provenían de otras naciones que habían pertenecido a la Unión de Repúblicas Socialistas Soviéticas. En su gran mayoría eran sujetos provenientes de Ucrania, aunque nos informaron también de la posibilidad de encontrar bielorrusos, lituanos y armenios. Además, dentro de esta categoría solían incluirse igualmente polacos, quienes formalmente 
no pertenecieron a la URSS. En este estudio optamos por entrevistar no sólo a personas provenientes de Rusia, sino también de Ucrania, lo que tuvo como consecuencia una mayor diversidad de puntos de vista.

El hecho de que estos sujetos fueran catalogados todos bajo el apelativo de "rusos" no es algo particular y exclusivo de esta migración. Por el contrario, en los estudios sobre migraciones se hace evidente cómo grupos de inmigrantes de distintas nacionalidades son llamados por un mismo apelativo por la sociedad receptora, con el fin de identificarlos, como lo veremos en el desarrollo de este estudio. Tal es el caso del grupo de inmigrantes denominados como "árabes" en la costa Caribe, grupo que reúne indistintamente ciudadanos provenientes del Líbano, Palestina y Turquía.

Del total de 15 sujetos, 10 fueron mujeres y 5 hombres, llegados al país durante la perestroika o los años inmediatamente posteriores. El hecho de que trabajáramos con más mujeres que hombres se relaciona con que muchas de las inmigrantes eran mujeres que se habían casado o tenían fuertes vínculos con colombianos que previamente habían estudiado en la entonces Unión Soviética. Aunque no pretendíamos realizar un estudio que comparase el ciclo vital, podemos distinguir dos grupos etarios: el primero, al que pertenecen la mayoría de los sujetos entrevistados (11), va de los 40 a 70 años, y el segundo, de los 24 a los 30 años. Estos últimos llegaron con sus padres. En todos los casos, y como una medida de respeto y confidencialidad, los nombres de las personas que amablemente nos colaboraron narrándonos sus historias 
fueron cambiados por otros, al igual que los nombres de las personas a las que hacen referencia.

Como ayuda para ordenar la información recolectada y analizar los cursos de vida de los sujetos investigados, optamos por usar el software de análisis cualitativo Nvivo8. El procedimiento que adoptamos, concordando con Marsvati, inició con la creación de categorías iniciales reelaboradas continuamente, "para ajustarse a los matices del tema". ${ }^{6} \mathrm{El}$ análisis inicial fue guiado por los grandes temas principales que emergían de las entrevistas, en este sentido nos apoyamos en la Grounded Theory, en tres pilares fundamentales. Primero, la búsqueda de categorías emergentes a partir de un análisis temprano de la situación; segundo, la construcción de categorías que explicaran y sintetizaran los procesos; y tercero, la integración de dichas categorías encontradas inductivamente con teorías establecidas capaces de explicar los fenómenos estudiados. Con esto presente, en el capítulo siguiente abordaremos la historia migratoria, tanto de América Latina como de la ex Unión Soviética, haciendo un recorrido que abarque no solo su historia, sino los puntos de vista teóricos desde los cuales se ha tratado.

6 Marsvati, Amir. "Qualitative”. 


\section{Capítulo I. Dos historias paralelas}

\subsection{Latinoamérica: una mirada general a las inmigraciones}

Los mayores movimientos migratorios que llegaron a la región de Latinoamérica y el Caribe lo hicieron desde mediados del siglo xIx hasta principios del siglo xx, la mayoría provenientes del sur de Europa. ${ }^{1}$ Se calcula que en parte de estas dos centurias más de 52 millones de personas salieron de Europa para establecerse en otros continentes. ${ }^{2} \mathrm{La}$ región latinoamericana y del Caribe recibió el $21 \%$ de las migraciones totales a América. Argentina y Brasil, seguidos por Uruguay, Cuba y Chile fueron los países que más inmigrantes recibieron. Italia, España y Portugal y, en menor medida, Alemania y Rusia fueron los países de procedencia de la mayoría de inmigrantes que arribaron a la región. ${ }^{3}$

1 La sobrepoblación en los países europeos, las guerras civiles, las revoluciones, las crisis económicas por la pérdida de colonias y las persecuciones políticas y religiosas que se dieron en esta época fueron factores importantes de expulsión de una cantidad considerable de la población europea.

2 Soto, Carlos. Condición de los extranjeros en Colombia. Bogotá: Editorial Posse, 1930. Impreso.

3 Martínez, Jorge. El mapa migratorio de América Latina y el Caribe, las mujeres y el género. Santiago de Chile: Celade, 2003. Impreso. 
La llegada de un porcentaje tan alto de migrantes europeos a Latinoamérica se debió en parte a que, para la época, los países latinoamericanos compartían la idea de la migración europea como instrumento de modernización y progreso. ${ }^{4}$ Los países que además de tener una gran demanda de mano de obra para la agricultura y la industria ofrecían al inmigrante estímulos tales como leyes de protección e incentivos económicos, rutas de llegada, infraestructura adecuada y una economía estable fueron los que lograron con éxito esta tarea. ${ }^{5}$

Producto de la transformación económica favorable que vivió Europa, para la segunda mitad del siglo xx, el panorama migratorio cambió en la región. La migración a la región latinoamericana se redujo significativamente y se registró un retorno de inmigrantes hacia sus países de procedencia. Según datos del proyecto de Investigación de la Migración Internacional en Latinoamérica (Imila), entre 1970 y 1990 la migración intercontinental a Latinoamérica y el Caribe se redujo casi un $50 \%$, estableciéndose un nuevo patrón migratorio: la migración intrarregional. ${ }^{6}$ En adelante, las migraciones de europeos a Latinoamérica cesaron para ser sustituidas por migraciones entre países vecinos.

4 Martínez, Frédéric. “Apogeo y decadencia del ideal de la inmigración europea en Colombia, siglo xIx”. Trad. Ximena Fidalgo. Boletín cultural y Bibliográfico 34.44 (1997): 3-45. Impreso.

5 Villa, Miguel y Jorge Martínez. El mapa migratorio internacional de América Latina y el Caribe: patrones, perfiles, repercusiones e incertidumbres. Santiago de Chile: Celade, 2001.

6 Ibid. 
Para los años sesenta y setenta, como consecuencia de las dictaduras y los problemas sociopolíticos que empezaron a generarse en la región latinoamericana y del Caribe, la migración hacia países fronterizos dentro de América Latina se duplicó, mientras que para los años ochenta, por el impacto de la crisis económica que sufrió la región y que afectó a los países receptores, las migraciones entre países fronterizos disminuyeron.

Con el cese de la migración intercontinental y la estabilización de la migración intrarregional en Latinoamérica, para las décadas de los ochenta, noventa y lo corrido del siglo xxi, la región entró en una nueva etapa, caracterizada por las emigraciones extraregionales, es decir, de ciudadanos de Latinoamérica hacia otros continentes y subcontinentes, siendo una de las principales la que se presenta hacia los Estados Unidos y Canadá. Sin embargo, aunque la migración intrarregional no alcanza las magnitudes anteriores, aún existe una migración al interior de la región. De igual forma, aunque la migración extrarregional se disminuyó de manera considerable, esta no fue nula. Las inmigraciones, aunque menores en escala numérica a las emigraciones, también son parte preponderante en la historia de la región.

\subsection{El sueño que no se hizo realidad: el inmigrante ideal y los debates políticos en Colombia}

Al igual que el resto de Latinoamérica, para el siglo XIX Colombia compartió el deseo de migración europea, vista como sinónimo de modernización y "blanqueamiento" de la población. Pero, a diferencia de otros países de la región, 
Colombia no fue receptor de grandes flujos migratorios, pues no necesitaba la importación de mano de obra agrícola para trabajar la tierra -existía mano de obra nativa de sobra. Además, el país no contaba con una actividad económica consolidada, estable e importante. Por tanto, el deseo de inmigración y las leyes constituidas para su realización "se basaron principalmente en el ideal de los gobernantes colombianos de impulsar la importación de ciudadanos, de preferencia europeos blancos, como material de progreso, más que en una necesidad real".

La migración apareció entonces como un instrumento del Estado. Se trató de un afán del gobierno por homogeneizar y civilizar a los colombianos mediante la ocupación $\mathrm{y}$ transferencia de territorios a los inmigrantes europeos. El inmigrante ideal para el Estado era aquel que además de traer conocimiento -capital cultural-, capital económico y herramientas de su país de origen, estimulara la inmigración de más de sus compatriotas e invirtiera en los terrenos baldíos que les iban a ser concedidos. Además, estaba dentro de sus tareas la de propender por los valores morales y cívicos de la población a la que llegase, siendo uno de los objetivos del gobierno educar y civilizar las clases inferiores a través de la inmigración.

El Estado, intentando incentivar el arribo de extranjeros, planteó distintas leyes durante el siglo xix, que contemplaban, entre otras cosas, la concesión de tierras y el apoyo económico a los inmigrantes. Las más destacadas fueron las

7 Martínez, Frédéric. “Apogeo”. 
leyes de inmigración de extranjeros de 1847, la Ley de 1871 y la Ley de 1892. La Ley de Inmigración de Extranjeros de 1847 propuesta por Manuel Ancizar, el secretario de relaciones exteriores para la época, estipulaba la concesión de tierras y la ayuda financiera de 50 pesos a cada inmigrante que decidiera establecerse en la Nueva Granada. Además, el plan contemplaba subsidios y bonos a los cónsules que incentivaran la migración en los que ejercieran su labor, propendiendo por dar a conocer el país como un lugar propicio para el arribo y establecimiento de europeos. ${ }^{8}$

El proyecto Ancizar fue un total fracaso por dos razones: en primer lugar hubo poca voluntad política de diplomáticos dentro y fuera del país para "importar" extranjeros, y en segundo lugar, porque los presupuestos necesarios eran demasiado altos. Igualmente, la no aprobación del presupuesto estimado para la ayuda económica del inmigrante, por falta de capital del Estado, provocó que los proyectos de inmigración que se habían puesto en marcha tuvieran que ser cancelados. Aunque ineficaz e inaplicable, la Ley 1847 de Inmigración de Extranjeros siguió vigente hasta 1890, suscitando esporádicos debates a lo largo de este tiempo.

Para la década de los cincuenta del siglo xix, el ideal de la inmigración europea como forma de progreso y civilización siguió estando presente en la agenda del gobierno. Diego Paredes, secretario de relaciones exteriores para 1850, estimuló la firma de contratos con empresas de migración. Esta nueva estrategia tampoco dio muchos resultados, aunque para

$8 \quad$ Ibid. 
1852 se estableció Geo Von Lengerke en el Estado soberano Santander, quien atrajo a la región a más familias alemanas que impulsaron el comercio y la explotación de la quina en el departamento.

Para la primera mitad del siglo XIX el Estado se concentró en impulsar la llegada de europeos blancos, de agricultores de la Europa industrializada que supieran manejar las máquinas modernas, como es el caso de suizos alemanes y de suecos. Ya para la segunda mitad del siglo xix las miradas fueron más realistas y aceptaron que Colombia no tenía las mismas posibilidades de otros países de tener una migración exitosa, y que resultaba absurdo seguir guiándose por modelos de inmigración de países como Estados Unidos y Argentina.

Para 1871 se dio otro intento por legalizar la entrada de extranjeros al país. Salvador Camacho Roldán propuso para este año la Ley “sobre la protección de extranjeros" que, a diferencia de la Ley de 1847, en lugar de perseguir el arribo de grandes masas migratorias, intentó establecer un ambiente jurídicamente propicio para los inmigrantes que llegasen a establecerse. Esta ley era más realista, en cuanto al hecho de aceptar que la migración que se daba a la región era una migración esporádica, individual o que solo involucraba el núcleo familiar. La ley buscaba la creación de juntas que ayudaran a los extranjeros pobres que arribasen a los puertos de la Nueva Granada a conseguir donde instalarse, prestarles la información necesaria, respaldarlos y ayudarles a conseguir dónde establecerse al interior del país, ya que el clima de la zona costera no era el más propicio para los inmigrantes europeos. Otro punto importante de la ley establecida por 
Roldán se refirió al hecho de ampliar las posibilidades de procedencia de los extranjeros que llegasen al país, advirtiendo que no solo la migración proveniente de Europa podría ayudar al progreso de la nación.

A diferencia del plan Ancizar, la Ley "para la protección de extranjeros" contó con la voluntad política y con la aprobación y concesión del presupuesto requerido. Gracias a la ley se crearon con éxito las juntas para el apoyo de inmigrantes en Barranquilla y Santa Marta y se emprendieron nuevos proyectos de inmigración. Sin embargo, los nuevos proyectos migratorios fracasaron y las corrientes que estaban llegando al país desde décadas anteriores cesaron. Esta vez el fracaso se debió, más que a la falta de voluntad gubernamental, a las enfermedades, a la falta de recursos y de vías de comunicación en las zonas colonizadas, además del clima poco favorable para los proyectos agrícolas. Asimismo, para 1879 fueron asesinados en la ciudad de Bucaramanga dos alemanes en motines presentados después de elecciones locales. Después de estos hechos cesó la migración alemana y se interrumpieron los proyectos que vinculaban a ciudadanos de dicho país.

Para finales del siglo xIX el sueño de la migración volvió a ser un tema primordial para el Estado colombiano y se dio el esfuerzo más grande del siglo para lograrla. Es así que en 1892 se votó la Ley 117. Esta ley perseguía la llegada de trabajadores para diferentes actividades relacionadas con la agricultura y la industria, especialmente para el cultivo de café y la caña. Para dar inicio se designó un comité gubernamental para firmar los contratos con las empresas de migración y se 
aprobó un presupuesto de 150000 pesos anuales. Se esperaba la llegada de italianos y españoles agricultores al territorio nacional, además de la llegada de rusos a los Llanos Orientales. Sin embargo, todos los proyectos fracasaron y el siglo XIX se cerró sin lograr la llegada masiva de extranjeros. Esto fue adjudicado, en parte, a la guerra de los Mil Días que se desató en el país para finales del siglo y que terminó por frustrar la llegada de extranjeros por mucho tiempo. ${ }^{9}$

Fueron muchas las razones para que el sueño migratorio fracasara durante todo el siglo xix. Entre otras: países de la región como Argentina, Venezuela, Brasil y Estados Unidos brindaban a los inmigrantes mejores condiciones; el poco conocimiento que existía de Colombia en Europa; las dificultades geográficas y climáticas; las guerras civiles frecuentes; la debilidad de las finanzas públicas que no podían reducir los costos de instalación de los inmigrantes; la inexistencia de una ruta desde Europa a Colombia; la precariedad de las vías de comunicación; la baja actividad económica del país; $\mathrm{y}$, por supuesto, las leyes que pretendían seleccionar a los inmigrantes, regular su movilización y menguar la llegada de "inmigrantes indeseados".

Ya en el siglo xx, Colombia se caracterizó, desde los años cincuenta hasta finales de los años ochenta, por ser uno de los países de la región que más restricciones puso a la inmigración, incluso se controló bastante la expedición de visas y la llegada únicamente de extranjeros que cumplieran cierto perfil profesional. No obstante, para la década de los noventa

9 Ibid. 
hubo una "tendencia hacia la apertura y consolidación de las relaciones internacionales", ${ }^{10}$ aunque la integración fue buscada más hacia lo regional.

\section{3. ¿Y qué paso en realidad? Los inmigrantes que llegaron a Colombia}

Aunque fueron pocos los inmigrantes que llegaron al país desde el siglo XIX, si se les compara con la población total colombiana, ${ }^{11}$ su gran aporte en el desarrollo y modernización del país y, en particular, de las ciudades en las que se establecieron, es aún notorio. Entre muchos de los aportes que hicieron los migrantes al desarrollo del país se encuentran los adelantos tecnológicos para la explotación de minas, el desarrollo del comercio, la creación de rutas y medios de transporte, el desarrollo de la agroindustria, además de los aportes al conocimiento de la medicina, la música, la literatura, la metalurgia, la ferretería y el manejo de maquinarias. Según García, "la escasa cuota de modernidad que logró nuestra sociedad para comienzos del siglo xx, se debió a la presencia de los inmigrantes". ${ }^{12}$

Además, resulta innegable la influencia de los inmigrantes en la cultura colombiana. Como bien lo expone el historiador antioqueño Rodrigo García, "los contactos entre los nativos y los forasteros cambiaron la forma de pensar,

10 Ibid.

11 Para 1939, el número de extranjeros que residían en nuestro país no excedían el 0,35\% de la población total de Colombia.

12 García, Rodrigo. Los extranjeros en Colombia. Bogotá: Editorial Planeta Colombia, 2006. Impreso. 
de vestirse, de comer y de divertirse"13 de los colombianos. Fueron los inmigrantes los que crearon clubes sociales y los que impusieron nuevas formas de vestir con la importación de textiles y zapatos, también fueron los que comenzaron a practicar deportes antes no conocidos como el fútbol, tenis, beisbol y golf. Todo esto terminó por modificar la forma de pasar el tiempo libre de la población local. ${ }^{14}$

Desde el siglo XviII se sabe de la llegada de inmigrantes a la Nueva Granada. Muchas de estas migraciones fueron impulsadas desde la corona, que buscaba incrementar la productividad y modernizar la explotación de oro y plata, por lo que vio la necesidad de importar ingenieros y técnicos franceses, ingleses y alemanes al occidente neogranadino. Tras el fracaso de muchos de los proyectos mineros, la mayoría de los inmigrantes asociados a este negocio retornaron a sus países. Sin embargo, otros permanecieron y terminaron por casarse con mujeres de la élite en Antioquia, Santander y Tolima, logrando, por medio de estas alianzas matrimoniales, "la aculturación y la adopción de costumbres neogranadinas, a la vez que aportaron cambios e innovaciones en los aspectos teórico económicos y en las costumbres de la elite". ${ }^{15}$

Para el siglo xix el país no tenía los recursos económicos y mucho menos el capital cultural para invertir en el desarrollo de la industria, así que, al igual que en la minería, fueron los extranjeros los que impulsaron esos sectores de la economía.

13 Ibid.

14 Ibid.

15 Ibid. 
Estos fueron los primeros en inaugurar astilleros, ferreterías, talleres de mecánica, laboratorios de ensayes, entre otros. Fueron los extranjeros además los que se encargaron en sus talleres de enseñar a los artesanos colombianos mecánica, ebanistería y herrería. Desde la segunda mitad del siglo xix, algunos alemanes se vincularon con la industria y comercialización de tabaco, quina, metales preciosos y café. Por su lado, los ingleses se encargaron de la explotación tabacalera en la Costa Atlántica, Antioquia y el Magdalena. En cuanto a la agroindustria del café, para el siglo xix los alemanes tuvieron grandes haciendas cafeteras en Santander y para el xx llegaron a Antioquia atraídos por la creciente producción cafetera a la cual muchos se dedicaron. El éxito económico que adquirieron los inmigrantes para finales del siglo XIx hizo que estos vieran la necesidad de abrir bancos. Es así que en Bucaramanga, Medellín y Barranquilla se abrieron los primeros bancos del país a manos de alemanes. Además, la creciente exportación e importación de productos motivó a estos extranjeros a abrir nuevas rutas comerciales. ${ }^{16}$

Según el historiador Rodrigo García, los inmigrantes que llegaron a la nación con capitales altos, altos recursos económicos y altos conocimientos, como el caso de los ingleses, daneses, franceses y alemanes, lograron un reconocimiento económico y social rápido que les facilitó su integración con las élites, a través de alianzas matrimoniales con familias

16 En cuanto a los productos que importaban los inmigrantes y vendían en sus grandes casas comerciales se encuentran los textiles, zapatos, vajillas, licores y hasta pianos. Ibid. 
reconocidas. No obstante, el país también recibió y se vio claramente influenciado por la llegada de aquellos migrantes no deseados por el gobierno. Paradójicamente, muchos de los procesos migratorios que lograron concretarse y terminaron en la llegada al país de extranjeros, fueron realizados por aquellos grupos que largamente habían sido llamados, por decir lo menos, "indeseados". Estos grupos fueron, sólo por citar algunos ejemplos, los japoneses, los siriolibaneses, los gitanos y los judíos.

A diferencia de los inmigrantes europeos, quienes venían con un alto capital cultural y económico, estos migrantes “indeseados” fueron estigmatizados y les resultó mucho más difícil su integración a la sociedad colombiana. Sin embargo, a largo plazo lograron posicionarse económica y socialmente, llegando a alcanzar un reconocimiento positivo en los lugares donde terminaron por establecerse e influenciar y aportar en campos diversos.

Tal es el caso de los sirio-libaneses que se establecieron en la Costa Atlántica, en Barranquilla principalmente, a finales del siglo xIx, a quienes se les solía calificar general y eufemísticamente de "poseedores de enfermedades y harapientos". ${ }^{17}$ Varias leyes se dictaron para restringir su ingreso y nacionalización, sin embargo estas migraciones prosperaron. ${ }^{18}$ En

17 Vargas Pilar, et al. Los árabes en Colombia. Del rechazo a la integración. Bogotá: Ed. Planeta, 1991. Impreso.

18 A finales del siglo xix e inicios del siglo xx, la comunidad árabe comenzó a ser reconocida como una comunidad importante e influyente en las regiones donde hacía presencia, hasta tal punto que lograron equipararse con las élites tradicionalmente "blancas". Ibid. 
cuanto a los japoneses, aunque de hecho existieron varios planes para su importación y asignación a labores agrícolas, principalmente en el Valle del Cauca, muchos fueron frustrados desde el gobierno; inicialmente fueron reconocidos positivamente, progresaron económicamente y mantuvieron sus costumbres, ${ }^{19}$ pero súbitamente, con el advenimiento de la Segunda Guerra Mundial, las condiciones cambiaron, rápidamente fueron estigmatizados e incluso segregados. ${ }^{20}$ Por último, sobre los judíos se ha documentado que se produjo una gran migración hacia Colombia en el siglo xx a causa de la Segunda Guerra Mundial. ${ }^{21}$ Aunque llegaron con poco capital económico, gracias a sus actividades comerciales innovadoras, como la venta puerta a puerta y a crédito, mejoraron su estatus notablemente en poco tiempo y pasaron de ser vendedores ambulantes a tener sus propios locales. ${ }^{22}$

Sobre las migraciones que han llegado al país desde la segunda mitad del siglo xx y lo corrido del siglo xxI existe un gran desconocimiento. Según datos arrojados por distintos censos, entre 1964 y 1985 se dio una inmigración cuantitativamente significativa a Colombia: según Cárdenas y Mejía,

19 Sanmiguel, Inés. "Japoneses en Colombia. Historia de inmigración, sus descendientes en Japón”, Revista de Estudios Sociales 23 (2006): 81-96. Impreso.

20 Algunos de los inmigrantes de la colonia El Jagual y otros pocos de Barranquilla fueron detenidos y trasladados al Hotel Sabaneta en Fusagasugá. Ibid.

21 Hernández, José Ángel. "Emigración Judía en Colombia en los Años 1930 y 1940. Un Caso Particular: los Polacos”. Revista Pensamiento y Cultura 10 (2007): 177-190. Impreso.

22 Los inmigrantes judíos tuvieron problemas al entrar a competir principalmente con los comerciantes locales, algunos establecimiento increpaban, como lo relata José Hernández, “este no es un negocio de judíos, adelante”. Ibid. 
"el número de inmigrantes se duplicó"23 para esta época, sin conocerse las razones de ello. Ya para el censo del 2005 se ve cómo el número de extranjeros viviendo en Colombia se redujo significativamente, llegando a ser el 0,22\% de la población total..$^{24}$ Los países de mayor procedencia de los inmigrantes que han arribado a la región durante el siglo xx son Venezuela, Ecuador y Estados Unidos. Sin embargo, la información recogida por los censos deja abiertas varias interrogantes, por ejemplo, sobre las regiones en las que se han establecido, las razones por las que llegaron al país y sus procesos de integración.

\subsection{Las migraciones y el desarrollo de un departamento: los extranjeros en Santander}

Santander fue uno de los departamentos que más registró extranjeros y que más influenciado fue por ellos. ${ }^{25}$ Fueron estos inmigrantes quienes crearon industrias, abrieron rutas comerciales, generaron centros sociales, comenzaron la extracción del petróleo, trajeron el alumbrado eléctrico a la ciudad de Bucaramanga, inauguraron los primeros bancos,

23 Cárdenas, Mauricio y Carolina Mejía. "Migraciones".

24 Colombia, Departamento Nacional de Estadística. Aproximación a la migración internacional en Colombia a partir del censo general 2005. Bogotá: DANE, 2006. Impreso.

25 Para el siglo xIx, siguiendo los ideales del gobierno central, el Estado Soberano de Santander tenía como propósito colonizar la región y explotar sus recursos con ayuda extranjera. Por tanto, prometió adjudicar terrenos baldíos a aquellos que viniesen con las herramientas y el capital necesario para invertir. Harker, Roberto. Bucaramanga: Los inmigrantes y el progreso, 1942-1992. Bucaramanga: Alcaldía de Bucaramanga, 1992. Impreso. 
ayudaron en la creación del aeropuerto, impulsaron la industria tabacalera y cafetera y exploraron las zonas selváticas hasta el río Magdalena. De estas manera, convirtieron a la postre a Bucaramanga en una de las principales ciudades del país para el siglo XIX. ${ }^{26}$

Los inmigrantes alemanes fueron unos de los que más influenciaron el desarrollo del departamento. Muchos llegaron para los años sesenta del siglo xIX, estableciéndose en Cúcuta, Ocaña, Bucaramanga y Socorro. ${ }^{27}$ Entre los inmigrantes alemanes más recordados se encontraba Geo Von Lengerke, ${ }^{28}$ quien comenzó a abrir el camino a Barrancabermeja, lo que posibilitó posteriormente la explotación de petróleo en el departamento. El éxito económico de Lengerke atrajo a más migrantes alemanes que comenzaron a invertir en el departamento. Entre las actividades económicas, los alemanes se destacaron por la industria cafetera, por la explotación de la quina en Sopó y por la explotación del río Magdalena como ruta comercial. Con la llegada de inmigrantes alemanes grandes almacenes comerciales empezaron a erguirse en el centro de la ciudad de Bucaramanga, se activó el comercio, se comenzó la importación de calzado y telas y la exportación de productos al resto del país. Leo Kopp, otro inmigrante

26 Para la época, era la primera ciudad en tener bancos, cervecerías y la mayor productora cafetera. Ibid.

27 Rodríguez, Horacio. Migración alemana al Estado Soberano de Santander en el siglo XIX. Bucaramanga: Editorial Kelly, 1968. Impreso.

28 Lengerke llegó al país después de haber asesinado a un compatriota. Al no tener el Estado Soberano de Santander una política de extradición, Lengerke terminó por establecerse en la región. Ibid. 
alemán, fue quien creó en 1882, en la ciudad de Socorro, la cervecería Bavaria, que es hoy la fábrica de cervezas más importante del país.

El auge comercial que lograron los extranjeros alemanes generó la necesidad de abrir bancos. Estos mismos fundaron el banco de Santander y el de Pamplona en 1872, los primeros que se abrieron en el país. Además, por la necesidad de crear un centro de reuniones y de diversión, los alemanes construyeron e inauguraron en 1872 el Club de Comercio en la ciudad de Bucaramanga. ${ }^{29}$ Todos esos oficios, actividades e implementos que trajeron estos inmigrantes cambiaron el modo de vestir, de actuar y de pasar el tiempo libre dentro de las ciudades donde se establecieron, cuestión que con el tiempo comenzó a generar inconformidad dentro de la comunidad santandereana.

Salvador Camacho Roldán describía que para 1879 Bucaramanga era explosiva: no sólo existía una rivalidad económica, sino también política, pues aunque los alemanes no podían votar para elecciones, financiaban a los candidatos de su conveniencia. ${ }^{30}$ Una muestra de las tensiones fueron los asesinatos de dos ciudadanos alemanes en Bucaramanga, el 7 y 8 de septiembre de 1879, en revueltas provocadas después de las elecciones. ${ }^{31}$ Como consecuencia de estos hechos, la

29 Ibid.

30 Camacho Roldán, Salvador. Escritos Varios (tomo I). Citado en Rodríguez, Horacio. "Migración”.

31 En los testimonios recogidos a los detenidos por estos hechos se puede ver el resentimiento del pueblo con los extranjeros establecidos: "Pues bien, por ese odio tan justo que el pueblo honrado le ha profesado a esos corrompidos 
llegada de extranjeros a la región así como el auge económico cesaron. Bucaramanga retrocedió económicamente, pues muchos comerciantes se fueron, se cerraron industrias dirigidas por extranjeros y el Banco de Santander fue liquidado.

Hacia 1882, gran parte de la colonia alemana había abandonado Bucaramanga. Unos partieron a otros departamentos, otros volvieron a su país de origen, otros migraron a Venezuela y otros tantos se dispersaron por otras ciudades de Santander. Sin embargo, se dice que los alemanes que permanecieron en el departamento terminaron por integrarse de forma satisfactoria a la sociedad santandereana. Como lo explica Horacio Rodríguez, "la fusión que al principio tuvo dificultades y hasta hechos de sangre, terminó destacándose y se realizó, aunque de forma muy local con plenitud satisfactoria". 32

Por otra parte, también se conoce de la presencia de ingleses en el departamento de Santander desde las guerras de independencia, pues una compañía inglesa luchó por tierras santandereanas. Muchos otros vinieron atraídos por las minas de Baja y Vetas y se dedicaron a su explotación. Fue un inmigrante inglés de apellido Jones quien trajo a la ciudad de Bucaramanga las plantas eléctricas, así Bucaramanga se convirtió en la segunda ciudad del país con alumbrado público. ${ }^{33}$ Después de que los ingleses abandonaron las minas,

extranjeros, y a su secuaz el comercio, ellos nos han apostrofado llamándonos guaches y canallas". Ibid.

32 Ibid.

33 Harker, Roberto. “Bucaramanga”. 
los migrantes franceses llegaron a Santander y retomaron su explotación. La explotación minera no fue la única actividad con la estuvieron relacionados los franceses, también tuvieron relevancia en el comercio, la explotación petrolera, las empresas de aviación en el departamento y la fundación del primer centro hotelero de Santander: el Hotel Bucarica. También se conoce sobre la llegada de daneses para el siglo xIx, quienes se establecieron en la ciudad de Bucaramanga. Entre estos, los más destacados fueron los Clausen, que llegaron en 1882 atraídos por el negocio de la quina. Cristian Clausen creó en 1887 la primera cervecería del país. A partir de la creación de esta fábrica se dió una inmigración de técnicos daneses que llegan a la ciudad para colaborar en la labor de la cervecería. Se sabe además de daneses que migraron a la ciudad de Bucaramanga para los años noventa del siglo XIX con el fin de trabajar en la compañía eléctrica, siendo pocos los que permanecieron o dejaron descendencia en la región. Además de los alemanes, ingleses y daneses, otro grupo representativo de inmigrantes en la región fueron los italianos. Estos inmigrantes fueron reconocidos por la producción de café, la industria, el comercio y el apoyo al desarrollo de la infraestructura en la región. ${ }^{34}$

Ya para finales del siglo XIX y principios del siglo xx, como sucedió en otras regiones del país, llegaron migraciones de sirio-libaneses, palestinos y judíos, y aunque el Estado

34 Los Atromachi y la familia Ogliastri fueron reconocidos por la producción de café en sus haciendas y Domingo Negrelli es recordado por los puentes fijos que instaló en la ciudad de Bucaramanga y en Floridablanca y por el puente colgante sobre el río Suárez, que per mitió la comunicación con Zapatoca. 
Soberano de Santander no pretendía la llegada de estos inmigrantes a su territorio, estos terminaron por establecerse. A diferencia de los alemanes, ingleses y daneses que llegaron a la ciudad con capital para invertir, estos llegaron con escasos recursos económicos, lo que según Harker dificultó su integración. ${ }^{35}$

Los inmigrantes libaneses que llegaron al departamento a finales del siglo xIx comenzaron a enviar remesas al Medio Oriente, lo que trajo la inmigración de más libaneses. Los libaneses fueron reconocidos por manejar la industria de la esperma en Bucaramanga. Por su lado, los palestinos comenzaron a establecerse en el comercio con la importación de telas de Inglaterra y Suiza y en poco tiempo lograron una estabilidad. Sobre los judíos, se sabe que en 1871 llegaron a la ciudad de Bucaramanga, procedentes de Portugal y de Polonia. Fueron reconocidos en la ciudad por ser grandes comerciantes, por esto mismo una calle del comercio era conocida en la ciudad como el corredor polaco. No obstante, muchos se fueron de la ciudad después de establecerse el nuevo Estado de Israel, y otros partieron después de que en 1967 dos inmigrantes judíos fueron asesinados en la ciudad al intentar resistirse a un secuestro.

Aunque todos estos inmigrantes lograron integrarse a la ciudad de manera satisfactoria, en principio fue difícil su aceptación, como en el caso de los judíos y libaneses, quienes al principio eran tildados de "harapientos" por la comunidad receptora. Sin embargo, con el tiempo lograron posicionarse

35 Harker, Roberto. "Bucaramanga". 
dentro de las ciudades de Cúcuta y Bucaramanga, gracias a sus formas exitosas de comerciar y, aunque, según Harker, no se integraron con las élites de las regiones en las que se establecieron, ni registraron gran cantidad de matrimonios mixtos, como los alemanes o ingleses, sí lograron ser reconocidos y aceptados, al punto que hoy en día pequeñas comunidades de libaneses y palestinos, conocidos como "turcos", conservan el negocio de las telas. ${ }^{36}$

Por último, Harker afirma que en la región santandereana se asentó una familia rusa de apellido Zerh, atraída por las minas de Baja y Vetas. No obstante, la documentación presentada por Harker no brinda más detalles, lo que hace difícil rastrear lo que aconteció con estos inmigrantes.

Desde una perspectiva histórica, puede apreciarse el hecho de que el capital, en forma de capital económico y capital cultural, jugó un papel importante en la integración de los inmigrantes, destacando el hecho de que aquellos que venían con mayores capitales lograron insertarse en las élites locales urbanas de una forma rápida. En contraparte, aquellos inmigrantes que llegaron con pocos recursos, bajo capital económico y bajo capital cultural, se insertaron con mayor dificultad, de facto tendieron a ser, al menos en principio, marginados y asignados casi que exclusivamente a labores agrícolas, como el caso de los japoneses, o al comercio al menudeo, como los entonces llamados "turcos" o los judíos.

Ya durante la segunda mitad del siglo xx fueron pocos los extranjeros que llegaron a la región, en comparación con

36 Ibid. 
los cincuenta años previos, a pesar de lo cual resulta notoria la presencia de algunos inmigrantes de distintas procedencias en la capital del departamento, de los que, infortunadamente, no se tiene mucho conocimiento sobre sus procesos migratorios. Chinos, japoneses, ucranianos, franceses, rusos, polacos, entre otros, se han establecido en la ciudad de $\mathrm{Bu}-$ caramanga sin que se sepa mucho sobre ellos, sus procesos de integración ni las historias que los rodean.

\subsection{Del Imperio ruso a la perestroika: las migraciones en la Unión Soviética}

Al otro lado del Atlántico, en la región este de Europa y la parte más occidental de Asia -en lo que fue primero el Imperio ruso y luego la Unión Soviética- las migraciones se caracterizaron por ser dominantemente internas. Pero, durante la perestroika y posperestroika, a finales de los años ochenta e inicios de los noventa, las migraciones pasaron abruptamente a ser externas. Como lo sentencia Pilkington: "Rusia y los países de la Ex Unión Soviética pasaron de ser países donde prácticamente sólo existían movimientos internos, a ser una de las regiones que a finales del siglo xx contaba con uno de los mayores números de emigrantes". ${ }^{37}$

Para entender este fenómeno es menester mencionar dos cuestiones fundamentales para comprender el contexto de las migraciones en este caso en particular: el trasfondo

37 Pilkington, Hilary. Migration, Displacement, and Identity in Post-Soviet Russia. London: Routledge, 1998. Impreso. 
geopolítico de las repúblicas soviéticas y el trasfondo étnico de sus habitantes.

\subsubsection{Geopolítica y multiculturalidad del Imperio ruso y la Unión Soviética}

El territorio ahora ocupado por los países ex miembros de la Unión Soviética-URss- es quizás uno de los que más ha experimentado cambios recientes en cuanto a su geopolítica, pues sus fronteras se trazaron varias veces durante el siglo XIX hasta el presente, cuando continúan definiéndose.

Desde el siglo XviII hasta inicios del siglo xx los territorios del Imperio ruso se extendían no sólo por Europa y Asia, sino también próximos a América, debido a los territorios de Alaska que limitaban en Bering y que después fueron vendidos a los Estados Unidos. El imperio estaba compuesto además por lo que actualmente es Rusia, Ucrania, Bielorrusia, la parte oriental de Polonia, Moldavia, el Cáucaso, Finlandia, varias regiones asiáticas y parte de Turquía, configurando un territorio vastísimo y muy diverso, étnicamente hablando. Sin embargo, con la revolución republicana del 1917 y después con la Revolución Bolchevique, el panorama cambió nuevamente, no sólo porque las fronteras se reconfiguraron, sino porque administrativamente hubo cambios profundos, en los que la cuestión étnica fue determinante. ${ }^{38}$

El resultado fue que entre 1922 y 1924 varias naciones, que en el pasado componían el territorio del Imperio ruso, pasaron a ser miembros de la URss, otros se mantuvieron

38 Ibid. 
como estados libres asociados. Según Lovell, historiador inglés de asuntos soviéticos y postsoviéticos, la construcción de la uRss fue vista en el momento como "el paso histórico de la oscuridad a la luz, del nacionalismo al internacionalismo, de la pobreza a la prosperidad, de la división de clases a la unidad social". ${ }^{39}$ Todo esto derivó en la asociación federativa de Armenia, Azerbaiyán, Bielorrusia, Estonia, Georgia, Kazajastán, Kirguistán, Letonia, Lituania, Moldavia, Rusia, Tayikistán, Turkmenistán, Ucrania y Uzbekistán que duró hasta 1991.

Estos cambios, liderados por Lenin, fueron importantes en términos geopolíticos, pues significaron el paso de un régimen colonialista a un Estado federalista como fue, o al menos proclamó ser, la Unión de Repúblicas Socialistas Soviéticas, en las que las fronteras se dibujaron procurando corresponder a las fronteras etnológicas. En marzo de 1921 se estaban tomando los pasos definitivos para convertir a las ex naciones del imperio en una confederación, dando a las minorías nacionales alguna autonomía cultural, organizacional y administrativa, colegiada por el Partido Comunista de la Unión Soviética (PCS), radicalmente diferente a lo que se hacía en la época imperial. A pesar de las iniciativas que promovían el multiculturalismo, en realidad la hegemonía cultural y política eslava era patente.

De Lenin a Stalin, se presentaron cambios en cuanto a las políticas para las naciones, pues en la era de Stalin se percibió

39 Lovell, Stephen. The Soviet Union: a Very Short Introduction. Oxford: Oxford University Press, 2009. Impreso. 
que dichas políticas impedían la creación de una identidad nacional soviética y reafirmaban las tensiones étnicas. Este cambio de políticas, en el gobierno de Stalin, orientadas a la homogenización de los soviéticos, terminó por reafirmar las tensiones étnicas y la imposición eslava sobre las otras nacionalidades. En realidad la hegemonía eslava, y particularmente la rusa, fue notoria, ya que los eslavos componían cerca del $40 \%$ de la población total de la federación. ${ }^{40}$

\subsubsection{La migración en la Unión Soviética}

Es importante anotar el hecho de que la migración interna y externa en la URss fue bastante regulada y existían leyes rígidas para controlarla. Así que para moverse, aún dentro del territorio de la Unión Soviética, era necesario el porte de la propiska, un pasaporte de uso interno para registrar el desplazamiento, garantizar, desde el Estado, una residencia para quien se movilizaba y como cartera laboral. En cuanto a las pocas migraciones externas que se dieron durante la URSS, según cuenta Ángela, una de nuestras entrevistadas, se daban a países igualmente socialistas: "el régimen facilitaba tu salida para países así, comunistas, con los que tenía algún tipo de convenio, pero para otra país era difícil, difícil”.

En cuanto a las migraciones hacia la URss, fueron escasas. Durante este periodo no fue un destino atractivo para las personas que vivían más allá de sus fronteras. En la primera

40 Thompson, John. Russia and the Soviet Union: A Historical Introduction from The Kievan State to the Present. London: Westview Press Inc., 2008. Impreso. 
mitad del siglo xx, de los 147 millones de personas de la Unión Soviética, alrededor de 400000 eran extranjeras y, según los datos, la movilización interna era del 7,4\%. ${ }^{41}$

\subsubsection{La urbanización}

Los primeros grandes movimientos migratorios dentro de la URss fueron causados por la industrialización de las principales urbes que se convertían en destinos atractivos, iniciando por la zona eslava, que fue la que más desarrollo alcanzó. A partir de los años veinte del siglo xx, Stalin lideró un nuevo proyecto que contemplaba la industrialización masiva, en los denominados planes quinquenales. Estos proyectos, que a largo plazo fueron exitosos económicamente, trajeron consigo una nueva migración de los campos hacia las ciudades y de las periferias a los centros, ahora un poco más diversificados, no exclusivos de la zona eslava.

A principios de los años 30, de acuerdo con Lorimer, la confederación estaba dividida en dos formas básicas, la región occidental, más europea, y la región oriental, más asiática. Las diferencias entre las dos mayores regiones eran palpables, la región occidental tendió a concentrarse en grandes ciudades, "las migraciones fueron principalmente un amplio movimiento hacia las ciudades", ${ }^{42}$ mientras que en la parte oriental la población se diseminó por territorios

${ }^{41}$ La única migración considerable de la época fue de Beilorrusia a Siberia, contando cerca de 200000 personas. Las partes centrales como Kirjistán, Uzbekistán, Tadjikistán y Turkmenistán casi no reportaron variaciones.

42 Lorimer, Frank. The Population of the Soviet Union: History and Prospects. Geneva: League of Nations, 1946. Impreso. 
rurales. En consecuencia, la parte occidental se industrializó más rápido que la oriental. Los flujos migratorios internos se caracterizaron por movilizaciones de personas que ya vivían en ciudades hacia ciudades industriales mayores, como Leningrado o algunas ciudades de Ucrania.

\subsubsection{Las migraciones desde el punto de vista étnico}

En cuanto a las migraciones internacionales, durante la existencia de la URss, aunque fueron pocas, hubo algunos flujos bien demarcados. La emigración desde 1960 fue de carácter casi exclusivamente étnico: quienes más emigraron tenían orígenes étnicos por fuera de los límites de la uRss y buscaban la reunificación familiar. Dentro de este grupo, los principales migrantes internacionales fueron los judíos, alemanes y griegos, $60 \%$ hacia Israel; $31,3 \%$ a Alemania y 5,3\% a Grecia, respectivamente. ${ }^{43}$ Estos flujos se intensificaron durante la perestroika en el momento en que se abrieron las fronteras.

El mosaico étnico que componía la Unión soviética lleva a considerar el hecho de que aunque la mayoría de las migraciones eran internas, suponían cambios culturales abruptos. Al hablar de migraciones en la Unión Soviética se está hablando de viajes largos, distancias enormes, que tocan las fronteras de Europa y Asia, desde Siberia, en el norte, hasta el sur del continente. A pesar de que se pueda considerar como una migración dentro de una unidad política, las diferencias étnicas y culturales eran muy marcadas.

43 Ibid. 
Los movimientos migratorios de la URss deben entenderse en su complejidad cultural y étnica. La Unión Soviética, compuesta por más de 175 nacionalidades, era un territorio vasto y bastante diverso. Aún los eslavos, el tronco étnico dominante, eran bastante diversos, lo que se refleja en la aparición de lenguas y costumbres propias. La parte norte de la Unión Soviética era poblada por los finos, quienes, a pesar de su origen étnico, eran culturalmente más semejantes a los rusos. El Cáucaso por su parte, que anteriormente ya había sido incorporado por el Imperio ruso, fue caracterizado como una región diversa y conflictiva entre los grupos étnicos durante la formación de la URss, como sucedió en la parte sur europea.

La conformación de la uRss puso en contacto directo y bajo directrices comunes nacionalidades étnicas que previamente habían estado en conflicto, ${ }^{44}$ pero lejos de mitigar estas diferencias durante el tiempo que existió, las tensiones fueron una constante, lo cual explica en parte por qué después de su desintegración emergieron tantos problemas con fundamento étnico en la región. La población eslava en cierta forma impuso, mediante las migraciones y la instauración del ruso como lengua vehicular ${ }^{45}$ y común, unos

44 El mayor contraste cultural dentro de la URss se presentó con los grupos históricamente diferenciados de la Rusia europea y las nacionalidades indígenas de la Rusia asiática: los agricultores de Asia central, los nómades de las estepas y las personas de la tundra de Siberia y el este lejano, con los que en general las relaciones pudieron denominarse como tensas, pues desde la llegada de los rusos a esa regiones los grupos aborígenes que poblaban esas áreas fueron casi exterminados. Ibid.

45 Es una lengua franca, usada para entenderse entre personas cuya lengua materna no es común. Pilkington, Hillary. "Migration”. 
patrones culturales marcados, pero no logró asimilar otros grupos étnicos cuyas culturas y procedencias étnicas eran divergentes. En cuanto a los eslavos con historias y culturas semejantes, como el caso de Ucrania y Rusia, después de la desintegración de la Unión Soviética volvieron a ser naciones administrativa y políticamente independientes. Sin embargo, como lo explica Pilkington, cuando Ucrania volvió a ser una nación independiente y el ucraniano fue nombrado el idioma oficial, un porcentaje muy pequeño de la población lo hablaba, siendo más usado el ruso y, en algunos casos, el polaco. ${ }^{46}$

\subsection{Las migraciones durante la perestroika y la posperestroika}

\subsubsection{Repatriación y conflicto étnico}

Durante casi 50 años, hasta los años noventa del siglo pasado, la URss disputaba con los Estados Unidos su hegemonía como primera potencia mundial, debido a su vasta influencia política y económica global. Para la URss, el siglo xx significó pasar de ser un territorio atrasado y pobre a ser una de las naciones más poderosas e influyentes. Sin embargo, cuando las reformas introducidas por Mikhail Gorbachov en 1991, conocidas como la perestroika, entraron en vigor, inició el colapsó de la Unión Soviética como unidad política y económica, trayendo numerosos consecuencias.

Quizá una de las consecuencias más graves fue que la desintegración de la Unión Soviética derivó en persecuciones

46 Ibid. 
étnicas, que prácticamente obligaron a los sujetos a salir de su país de residencia hacia los lugares donde se encontrara su origen étnico. Los países postsoviéticos se convirtieron en países de emigrantes; como manifiesta Kopnina, "los movimientos emigratorios desde los estados que anteriormente consolidaban las uRss habían entrado en una nueva etapa con un cambio cualitativo fundamental en su vida social, económica y política radical" ${ }^{47}$ Con el desplome de la Unión Soviética, la cuestión de la migración pasó a ser problemática, pues las diferencias y tensiones étnicas que anteriormente habían sido sosegadas volvieron a emerger y se exacerbaron en varias regiones. Por ejemplo, la hegemonía eslava durante la URSS causó que en la época post-soviética muchos resentimientos florecieran. Como lo recuerda Kopnina, muchos de los estados bálticos "crearon políticas de confrontación caracterizadas por tomar medidas para expulsar a los rusoparlantes". ${ }^{48}$

Estas nuevas políticas también estuvieron acompañadas por el surgimiento de grupos nacionalistas que en gran medida contribuyeron a la expulsión de las minorías eslavas y su repatriación. Muchos individuos que habían sido parte del flujo de migrantes internos antes de los años noventa, especialmente los de procedencia eslava, pasaron automáticamente a ser considerados migrantes externos esparcidos

47 Kopnina, Helen. East to West Migration: Russian Migrants in Western Europe. Aldershot: Ashgate Publishing, 2005. Impreso.

48 En ese momento 17,4\% de los rusos vivían fuera de Rusia, 15,3\% de ucranianos vivían fuera de Ucrania, $21 \%$ de bielorusos vivían fuera de Bielorrusia y $33,4 \%$ vivían fuera de Armenia. Ibid. 
en las diferentes repúblicas que anteriormente componían la federación. Aunque el caso de los eslavos en otras regiones fue el más significativo, en realidad esta situación afectó a todos quienes previamente habían migrado dentro de la Unión Soviética. Lo que a continuación experimentaron las nuevas repúblicas fueron movimientos contrarios a los que se habían emprendido antes, contraflujos en los que las personas migraron de vuelta a sus lugares de origen étnico. Esto no fue menos problemático, porque las nuevas fronteras geopolíticas no se ajustaron necesariamente a las fronteras étnicas.

\subsubsection{La migración postsoviética hacia el resto del mundo}

Este tipo de migraciones se caracterizaron por no pertenecer a los viejos patrones de emigración, como la reunificación familiar o el retorno a las tierras ancestrales. Se trató de la salida de habitantes de estos países a regiones distantes del mundo, principalmente los de origen eslavo, en busca de mejores condiciones de vida. Rusia y Ucrania fueron los países que más emigrantes registraron en los años posteriores a la desintegración de la URss. Los principales destinos fueron los países europeos, especialmente Alemania, Inglaterra y Francia. ${ }^{49}$ De acuerdo con Shevtsova, 452000 personas dejaron Ucrania en 1991, buscando residencia permanente afuera; este fue el periodo en el que hubo mayor migración

49 Pilkington, Hillary. “Migration”. 
internacional..$^{50}$ Fue en esta etapa que se produjeron las migraciones de los ciudadanos de las ex repúblicas soviéticas hacia los lugares que previamente no habían sido destinos migratorios, como es el caso de Colombia y en mayor medida Argentina.

Para entender los cambios que la perestroika introdujo y por lo cual se constituyó en un fuerte factor de expulsión, es necesario examinar ese periodo con mayor precisión. De acuerdo con Radnitz, hubo presiones estructurales y psicológicas sobre los habitantes que influenciaron y fueron decisivas en los procesos de emigración, como: el declive económico, la discriminación étnica, los requerimientos de lenguaje, la discriminación en los lugares de trabajo, la inconformidad étnica, la pérdida de estatus, entre otros. ${ }^{51}$ Aunque Radnitz sintetiza de manera adecuada este periodo, para comprender lo que realmente fue es necesario profundizar en estas reformas y su impacto sobre los sujetos, con el fin de entender cómo todos los factores que se vivían en las naciones soviéticas terminaron por influenciar la migración. Por este motivo, en el capítulo dos nos concentraremos en explicar la situación que se vivía en ese momento y cómo esta situación concluyó en la migración a Colombia de los sujetos aquí estudiados.

50 Shevtsova, Lilia. "Postsoviet Emigration Today and Tomorrow". International Migration Review 26.2 (1992): 241-260.

51 Radnitz, Scott. "What Really Happened in Kyrgyzstan?”. Journal of Democracy 17.2 (2006): 132-146. Impreso. 



\section{Capítulo II. "Nunca imaginé vivir en Colombia"}

\section{1. ¿Por qué salimos? El contexto expulsor}

\subsubsection{Contexto expulsor push}

Según Everet Lee, en las migraciones internacionales existen factores negativos - push-y factores positivos - pull-asociados a las áreas de origen y destino que terminan por motivar la migración internacional. ${ }^{1}$ Los factores negativos o factores de expulsión, como crisis económicas, escasez de oportunidades laborales, conflictos civiles, entre otros, asociados al área de origen, terminan por motivar a las personas a salir de sus países hacia lugares con factores positivos o de atracción, como una economía estable, desarrollo industrial y tecnológico, oportunidades laborales, etc. Ciertos factores empujan a la persona fuera de su área de origen mientras otros lo atraen al área de destino. ${ }^{2}$ Bajo este enfoque, las causas de la migración se encuentran tanto en el lugar de origen como en el lugar de llegada.

1 Lee, Everett. “A Theory of Migration”. Demography 3.1 (1966): 47-57. Impreso.

2 Ibid. 
Como vimos en el capítulo anterior, en el caso aquí estudiado es evidente que las naciones soviéticas estaban experimentando una situación acuciosa, con múltiples factores negativos de diversa índole, entre los que se incluían aspectos políticos, económicos y sociales, que incidieron en un grupo grande de la población que las habitaba, tanto en los años anteriores a su desintegración, como en los años subsiguientes a esta. Al ser esto evidente, algunos de los estudios que han tratado con anterioridad la migración de sujetos provenientes de las ex naciones soviéticas para la época de la posperestroika han centrado su atención en analizar la migración desde los factores negativos, tanto políticos como económicos, viéndolos como causas suficientes para explicar este gran fenómeno migratorio. Unos, haciendo más énfasis en los factores políticos y otros, en los factores económicos. A continuación revisaremos algunos.

Trabajos como el realizado por Radnitz se centraron en la crisis económica de las naciones postsoviéticas, indicando que los factores push económicos fueron los que determinaron la decisión de migrar de los sujetos, mientras los factores push políticos no fueron suficientes para producir la migración. ${ }^{3}$ Según Radnitz, "la construcción de las naciones y los nacionalismos influenciaron la decisión de migrar únicamente en cuanto que afectaron el bienestar material de

3 Para Radnitz los factores push son: declive económico, discriminación, requerimientos de lengua o ciudadanía, sistema político represivo, conflicto, guerra y desastre ecológico, discriminación en los lugares de vivienda, falta de conocimiento de la lengua, disconformidad étnica, pérdida de lazos sociales, pérdida de estatus. Radnitz, Scott. "What". 
las personas". ${ }^{4}$ El declive económico y la disminución del nivel de vida, así como la disminución de las posibilidades laborales, son referidos por este autor como principales factores expulsores.

Por su lado, trabajos como el de Remennick ${ }^{5}$ se centran en los factores de expulsión políticos como los motivadores de la emigración. Las políticas represivas para expulsar a los eslavos, especialmente rusos, de las otras repúblicas, la discriminación en lugares de trabajo por pertenecer a otras etnias, los conflictos en el Cáucaso norte por ejemplo, el presentado entre osetios e inguches en Osetia del Norte, fueron grandes fuerzas expulsoras que explican, según Remennick, por encima de la crisis económica que se vivía, la migración de los miembros de países postsoviéticos al resto del mundo. Valery A. Tishkov, por su lado, centra las causas de la migración en las tensiones étnicas y los etnonacionalismos radicales que fueron una constante en los años noventa en los países postsoviéticos. ${ }^{6}$ Para estos autores, los factores push políticos fueron los causantes de la emigración.

En el caso aquí estudiado, reconocemos que la gran crisis que se vivía en la Unión Soviética desde años antes de su desintegración es de vital importancia para entender las razones por las cuales migraron los rusos y ucranianos, aquí

\footnotetext{
4 Ibid.

5 Remennick, Larissa. Russian Jews on Three Continents: Identity, Integration, and Conflict. New Brunswick: Transaction Publishers, 2007.

6 Tishkov, Valery. Ethnicity, Nationalism and Conflict in and after the Soviet: the Mind Aflame. London: Sage Publications, 1997. Impreso.
} 
estudiados, que se establecieron en Bucaramanga. Sin embargo, no nos limitaremos a hacer énfasis en los factores push políticos o económicos como causas suficientes para la emigración.

Por el contrario, basándonos en las historias de vida recogidas en este estudio, sustentaremos dos afirmaciones. Primero, que estas migraciones no son causadas exclusivamente por factores políticos, económicos o sociales, como factores independientes, sino que son el resultado de todos estos factores en interacción. Segundo, aceptaremos la existencia de otros factores push ubicados en un nivel más micro, como las crisis psicológicas que sufrieron algunos sujetos, factores que para este caso peculiar fueron muy importantes.

Recordemos que los migrantes que participaron de este estudio llegaron en su totalidad en la última década del siglo xx. Algunos a finales de la perestroika, cuando aún no se había dado la desintegración de la URss, y otros, la gran mayoría, para la época conocida como la posperestroika, es decir, en el momento posterior a la desintegración oficial de la Unión de Repúblicas Socialistas Soviéticas. Por tanto, es menester explorar cuál era la crisis que se vivía antes y después de la desintegración de la URss para comprender a cabalidad cómo la situación de estas naciones intervino en la migración. De esta manera, comenzaremos explicando la situación en las naciones soviéticas años antes de su desintegración, para proseguir con la explicación de la crisis posterior a la disolución de la uRss.

Como mencionamos, la designación de Gorbachov como secretario general del Partido Comunista soviético concluyó 
con un cambio profundo de la realidad de las naciones que conformaban la URss en un sentido muy amplio: económico, político y social, producto de las reformas impulsadas desde el gobierno. Desde 1985, el conjunto de reformas conocidas coloquialmente como la perestroika -en español, reconstrucción-entraron en vigencia, promovidas desde el estamento. Estas se basaban en tres puntos principales: la reestructuración económica -la perestroika propiamente-, la liberalización política -Glasnost- y la democratización. Dichas reestructuraciones crearon distintas tensiones al interior de las naciones soviéticas, pues aunque tenían como objetivo el fortalecimiento del partido y de la economía -que estaba a puertas de la recesión-, terminaron paulatinamente por quebrantar la economía, acabar con el partido y alentar a las personas a dejar de creer en el socialismo, hasta llevar a la desintegración oficial de la Unión de Repúblicas Socialistas Soviéticas en $1991 .^{7}$

En cuanto a las reformas económicas, lo que instauró Gorbachov fue un programa de cinco puntos principales. La primera reforma, puesta en vigencia en 1988, buscaba la descentralización de la economía, permitiendo que algunas fábricas y otras unidades económicas fueran autosuficientes. Las empresas se volvieron autónomas para despedir y contratar personal. Además, podían escoger qué producir, cómo producirlo y cuánto producir, cuestiones que antes se planificaban desde el Estado. Una segunda reforma consistió en incentivar el comercio exterior y la inversión extranjera.

7 Thompson, John. “Russia”. 
Con esto se buscaba mejorar la tecnología soviética por medio de la inversión de países altamente tecnificados como Japón; las empresas también podían contratar proveedores foráneos y comprar productos extranjeros sin depender ya exclusivamente de la provisión estatal. La tercera reforma económica impulsada por Gorbachov apuntaba a la creación de un mecanismo de mercado para la compra de insumos, con el fin de que las personas racionalizaran la producción y buscaran los mejores productos. La cuarta reforma buscaba alentar a los pequeños negocios y las cooperativas para producir bienes relacionados con la industria ligera -la industria soviética había tenido predilección por la industria pesada desde la época de Stalin-, aunque estos negocios tenían que seguir pagando altos impuestos y las ganancias se dividían entre las personas que trabajaran en las cooperativas y el Estado. Por último, para ayudar a la economía rural, se dio a las familias o grupos pequeños la oportunidad de adquirir pequeñas parcelas. Estas personas ya no estaban obligadas a vender la producción total al Estado, sino que podían vender parte de ella en un mercado abierto.

Todas estas iniciativas recibieron fuertes críticas desde el partido, sin embargo, fueron recibidas positivamente en la esfera internacional, especialmente por los Estados Unidos. Durante los primeros años esta forma mixta de economía fue exitosa, aparecieron bienes y servicios de mejor calidad y se diversificaron los productos, aunque a precios muy altos. La economía soviética creció, pero fue algo efímero. En 1989 el crecimiento económico se detuvo otra vez y comenzó una gran crisis, los productos soviéticos no podían competir 
internacionalmente y a nivel interno muchos productos básicos comenzaron a escasear. Al adjudicarle más autonomía a las empresas, se incrementó la corrupción y creció el mercado negro, creando toda una economía paralela. Se redujo la inversión y sobrevino la inflación, hasta que el sistema se volvió económicamente insostenible. Para 1990 resultaba claro que los beneficios de las reformas económicas no habían sido tales, ni los propósitos de su instauración alcanzados. ${ }^{8}$

Por su parte el Glasnost ${ }^{9}$ fue una política de apertura del Estado hacia los habitantes, según la cual los individuos podían criticar al gobierno, aunque con cierta mesura. Se buscaba que fuera un ejercicio propositivo que mejorara la imagen del gobierno y modernizara su aparato estatal, bastante arcaico y hermético. Asimismo, el Glasnost buscaba crear una actitud positiva frente a las reformas económicas que al mismo tiempo se introducían. Durante este periodo muchos opositores del sistema, que habían sido aprisionados, fueron liberados. De igual manera, algunos personajes que habían sido expulsados pudieron retornar. El resultado del Glasnost fue que el Estado fue duramente increpado,

8 Las reformas de Gorbachov fueron en contra de los fundamentos sobre los cuales se había erigido la URSs, contradiciendo sus postulados que se sustentaban en la ideología comunista, que desde Lenin hasta Chermenko habían imperado sin vituperio. En estos se enfatizaba la centralización y la industrialización rápida y pesada, mientras Gorbachov perseguía la descentralización, la creación de industria ligera, la racionalización de la producción y, sobre todo, la propagación de unas formas incipientes de propiedad privada bajo la forma de titulaciones colectivas. Para profundizar, ibid.

9 La palabra Glasnost no tiene traducción al español, tampoco en inglés, aunque Thompson la traduce como "openness" (sic.), un estado de apertura, franqueza y recepción. 
especialmente desde los medios de comunicación y también por parte de ciertas élites intelectuales. Particularmente, el incidente ambiental de Chernóbil en Ucrania se tornó la punta de lanza de sus detractores, además de las reformas económicas que causaban malestar dentro de la población.

Por último, debemos comentar algo sobre la democratización, la tercera gran reforma introducida por Gorbachov. La democratización en el contexto de la uRss no puede ser entendida como el cambio hacia una democracia liberal al estilo occidental. La democratización en este caso debe entenderse como la apertura democrática pero manteniendo el sistema socialista. Es decir, desde Lenin se instituyó que el Partido Comunista soviético fuera el único posible y con Gorbachov esto no varió, sin embargo, lo que sí cambió fue el hecho de que sus representantes no seguirían siendo designados por el comité, sino que serían elegidos mediante votaciones. ${ }^{10}$

Estas tres reformas fueron las que terminaron por darle la estocada final a la confederación. Por una parte, las medidas fútiles para superar la recesión económica lo único que permitieron, al contrario de lo procurado, fue el ingreso de planteamientos y mecanismos capitalistas dentro del sistema socialista sin hacerlo más eficiente. Por otra parte, al mismo tiempo que el sistema era vehementemente criticado bajo el amparo del Glasnost, haciendo que se desacreditara el socialismo, las ideas democráticas ganaron fuerza. Así, las ideas de democracia y liberalismo económico avivaron el deseo

10 Thompson, John. “Russia”. 
de independencia de algunas naciones y alentaron los movimientos nacionalistas que cada vez tomaban más fuerza.

Aunque la mayoría de las veces la crisis soviética suele ser ubicada en el plano estructural, lo cierto es que las repercusiones que desencadenaron estas reformas afectaron no solamente a los países de la confederación en términos macroeconómicos y macrosociales, también afectaron profundamente las vidas y la cotidianidad de los habitantes de estos territorios. Las presiones estructurales que recaían sobre los individuos, como si fuera poco, generaron al nivel individual varias crisis de orden psicológico.

Algunos trabajos se han dedicado a estudiar las crisis psicológicas que fueron provocadas durante el periodo de transición del sistema socialista al capitalista. Por tomar un ejemplo, Värnik , en un estudio demográfico, concluyó que para el periodo de transición la tasa de suicidios fue considerablemente más alta, en promedio, de lo que había sido desde la Gran Depresión de los años treinta del siglo xx. ${ }^{11}$ Kon, por su lado, asevera que el colapso de la uRss ocasionó en los individuos una pérdida de sentido, al no tener más un referente nacional a partir del cual construir sus identidades, derivando en su fragmentación. Esto explica en parte el surgimiento de movimientos nacionalistas en búsqueda de la construcción de nuevas identidades nacionales. ${ }^{12}$

11 Värnik, Andrei. "Suicide in Estonia”. Acta Psychiatrica Scandinavica 84.3 (2007): 229-232. Impreso.

12 Kon, Igor. "Identity Crisis and Postcomunist Psychology”. Symbolic Interaction 16.4 (1993): 395-405. Impreso. 
El estudio de Värnik y las cifras sobre el incremento en las tasas de suicidio en el periodo de transición de las naciones soviéticas a naciones independientes puede explicarse bajo la luz de Durkheim. Este autor nos expone cómo los actos que parecen ser individuales, como el suicidio, tienen en sí una causa social. La anomia, es decir, la falta de normas que rijan una sociedad, que suele acaecer con el cambio de régimen moral y material, pueden llevar a un individuo a cometer suicidio. El hecho de que se incrementen los suicidios en una época determinada se debe, según Durkheim, a que "existe alguna fuerza social que inclina a todos los sujetos en ese mismo sentido, y cuya intensidad, más o menos grande, produce el número, mayor o menor, de los suicidios particulares" ${ }^{13}$ Esta cuestión resulta clara en el caso particular aquí estudiado, donde las presiones estructurales eran tales que las personas, al no poder salir del régimen, terminaban por intentar huir, acabar con sus vidas o con trastornos psicológicos latentes. Isabela, una de nuestras entrevistadas, narra: "Cuando yo salí mucha gente intentaba hacerlo, yo me casé y lo logré, pero mucha gente no pudo, tu veías gente trastornada, que se había vuelto loca por tanta presión".

La crisis económica, política y social que se vivía años antes de la disolución de la URss influyó directamente en la cotidianidad de las personas y llevó a muchas a desear salir, como bien lo manifiesta Olga, otra de nuestras entrevistadas: "Cuando vine, las cosas estaban cambiando en Unión Soviética, la llegada de Gorbachov y lo que implicó [...] entonces

13 Durkheim, Emile. El suicidio. Lima: Editorial Losada, 2004. 
todo esto hizo que la vida en Rusia cambiara [...] mucha gente salió en esa época, por eso tú vez aquí ucranianos, armenios, rusos”. Sin embargo, aunque eran múltiples los factores negativos que atizaban el deseo de muchos sujetos de partir de la URss en los años inmediatamente anteriores a su desintegración, no muchos lograron concretar su salida. Esto se puede explicar gracias a los obstáculos intervinientes a los que hace referencia Lee.

Como bien lo argumenta Lee, el volumen de la migración se explica no sólo por los factores push and pull en las áreas de origen y destino, sino que además está condicionado por los obstáculos intervinientes que existen en el proceso. ${ }^{14}$ En este caso concreto, existían sin duda obstáculos intervinientes de tipo político jurídicos. Pues, como habíamos referido en el capítulo anterior, aunque el Partido Comunista había cambiado las leyes que se referían a la migración, disminuyendo las restricciones para las movilizaciones fuera de los países soviéticos, este libre desplazamiento se redujo a un simple mandato constitucional que no se hizo efectivo. ${ }^{15}$ En la realidad las movilizaciones fuera de la confederación continuaron siendo bastante restrictas y reguladas desde los gobiernos. Estos obstáculos desde el estamento terminaron por restringir los movimientos migratorios. Lena, otra de las personas entrevistadas en este estudio, quien salió en 1990, cuenta desde su experiencia migratoria: "Cuando me iba [...] muy difícil salir de Rusia, si sales te cambiaban dólares

14 Lee, Everett. “A Theory”.

15 Thompson, John. “Russia”. 
estrictamente por un cierto curso, cierta cantidad, todo era todavía muy cerrado [...] yo me casé y fue más fácil permisos que para otros paisanos”.

Aunque la situación que se vivía dentro de la confederación era tensa, los ciudadanos seguían amparados por el Estado de bienestar soviético y sus servicios de salud, educación, transporte y alimentación seguían cubiertos. Esto también explica en parte por qué los flujos migratorios fueron mucho más bajos que después de la desintegración de la confederación, cuando el Estado de bienestar cayó y la situación empeoró. Esto dice Lena refiriéndose a Moscú en 1990: “Todavía todo era pues muy controlado, ¿’no? Era una ciudad con bastantes cosas culturales, todavía con pocas, digamos, ofertas de cosas para consumidores, pero buena cultura, buen transporte, todavía buena medicina en general para todos".

Una vez la URss se desintegró, emergieron no sin dificultad una serie de Estados independientes, herederos de una gran crisis económica, política y social. ${ }^{16}$ Lo que hizo que para la posperestroika las cosas se complicaran más. Las naciones que habían conformado la URss pasaron de tener una economía planificada y centralizada a ser naciones independientes, con economías de mercado. Pasaron acelerada y abruptamente de ser parte de una confederación socialista a ser naciones democráticas independientes, tendientes al capitalismo, lo que derivó en grandes conflictos que, como vimos, no se pueden reducir a lo económico o político.

16 Ibid. 
El cambio de sociedades socialistas a sociedades con una economía de mercado repercutió directamente en un cambio y en una gran crisis cultural, vivida en la cotidianidad de los sujetos. La apertura económica, la caída del Estado de bienestar soviético, la democratización, las tensiones étnicas, la libertad de expresión, la libertad de prensa, la apertura de las fronteras, la creación de nuevas naciones y nuevas identidades nacionales, entre otros muchos factores, terminaron por modificar las costumbres y la vida cotidiana de los habitantes de dichas regiones.

La apertura económica en las naciones postsoviéticas y la transformación hacia una economía de mercado produjeron un gran colapso. La baja capacidad para competir en el mercado, la acelerada hiperinflación y devaluación de la moneda fueron sin duda fuertes factores de expulsión para el grupo aquí estudiado. Como lo reitera Igor, uno de nuestros entrevistados: "Un día usted tenía 500 rublos y despertaba y todo vale por 3 más [...] por ejemplo se acostaba, un almuerzo valía 10 rublos y despertaba mañana y ya 20 rublos”. Esta crisis económica, además de generar un bajo nivel adquisitivo para las personas que dependían de un sueldo, generó una gran escasez de productos, una de las cosas a la que más se refirió el grupo de individuos que participaron en este estudio. Nina, otra entrevistada, cuenta que en Moscú “por la inflación lógicamente al decir que al otro día iban a subir los precios un $20 \%, 30 \%$, pues la gente se compraba todo hoy, porque era preferible comprar hoy con $20 \%$ de descuento todo, entonces de esa manera no quedaba nada en los almacenes". Sergey narra que lo mismo se vivía 
en Ucrania: "En un momento todos éramos millonarios en Ucrania, porque pagaban, pero no había nada para comprar con ese billete [risas], no había nada en las tiendas". Sabrina, madre de 4 hijos que se desempeñaba como docente, relata: "Para comprar unos productos que eran muy importantes para la familia, nosotras debíamos gastar 4 o 5 horas dentro de la cola [...] me tocaba cada 45 minutos en clase pasar por periodo de descanso de 10 minutos y correr y cuidar mi cola porque necesitaba azúcar, aceite, harina, esos, los productos más importantes, que no se conseguían”.

Como lo exponen Berger y Luckmann, la construcción de la realidad está asociada a la sociedad en la que los sujetos vivan, así que el cambio en las estructuras sociales deriva en un cambio en los hábitos y la cotidianidad de los sujetos. ${ }^{17}$ La escasez de alimentos, el desconocimiento en los negocios, la hiperinflación, el hecho de que los sueldos no la compensaran y, en fin, toda la gran crisis económica terminaron por transformar la cotidianidad de los sujetos, quienes tuvieron que cambiar su forma de vivir, sus hábitos y rutinas en un tiempo demasiado corto. Como lo narra Igor: "En esa época nadie trabajaba, porque salarios no alcanzaban para el trasporte, para ir al trabajo entonces toda la gente salió a la calle a vender lo que tenía. Fue toda la ciudad como un mercado grande, pero nadie antes había vendido nada". La crisis económica traspasaba y permeaba la vida de los ciudadanos, acentuando la crisis social y política, además de repercutir

17 Berger, Peter y Thomas Luckmann. La construcción social de la realidad. Buenos Aires: Amorrortu, 1986. Impreso. 
psicológicamente en los sujetos, quienes de manera acelerada habían cambiado su realidad. Como bien lo manifiesta Sandra, "la ciudad se transformó como una ciudad después de la guerra, la gente no sabe qué hacer, mucho desorden, mucha libertad, todos estábamos confundidos, como desorientados, tú ni sabías quién eras [risas]".

Con la caída del Estado de bienestar soviético por la desintegración de la URSs, la crisis social fue notoria y colapsó el sistema de salud, lo que derivó en un incremento de la mortalidad infantil y la propagación de epidemias en las naciones eslavas. El sistema educativo también cayó, las universidades se hicieron insostenibles y las personas que dependían directamente del Estado, como viudas, pensionados, veteranos e intelectuales, quedaron desamparadas. ${ }^{18}$ Adicionalmente, las personas estaban acostumbradas a ser provistas por el Estado, a vivir bajo un sistema de bienestar. Esto, sumado a la crisis económica y a los cambios profundos en las costumbres de las personas, terminó por dejar en la miseria a un porcentaje considerable de la población de las naciones postsoviéticas. Como bien lo referencia Igor, "la gente estaba acostumbrada a vivir cada día esperando, no tenía costumbres de hacer negocios y, bueno, se quedó mucha gente como en pobreza”.

Además, al entrar la democracia a países como Rusia y Ucrania se dio un cambio drástico, pasando del control por parte del régimen, a la libertad y a la concesión de derechos civiles, como la libertad de culto y de expresión, la libertad

18 Thompson, John. “Russia”. 
de empresa, la libertad para movilizarse dentro y fuera de las ya ex repúblicas soviéticas, el derecho al voto, el derecho a la propiedad privada, entre muchos otros, que se otorgaron de forma muy rápida y abrupta, lo que terminó por generar una gran crisis social e individual, porque las personas no estaban acostumbradas a vivir de este modo. Como bien lo señala Durkheim, la anomia, es decir, la ruptura de normas sociales y de control social, repercute en los individuos y los lleva a sentirse desorientados, al no encontrar un punto referente, unos objetivos, metas y valores sociales por perseguir. Es así que la ganancia de libertades individuales, que para algunas personas podría ser vista como algo positivo, para varios habitantes de la URss sólo generó estrés y angustia. Tal como lo narra Igor:

Antes todo era organizado [...] Nunca me permitieron salir, no me dejaron hacer muchas cosas, pero cuando pasó la caída de la Unión Soviética, vaya donde quiere, haga lo que quiere, entonces mucha libertad, pero poco orden. Antes estábamos como viviendo como en una jaula de la que no puedes salir, pero todo ordenado, sabe, hasta en orden le dan la comida y tú sabías. Ahora tienes mucha libertad pero no tienes comida, tuvimos libertad, pero un gran caos. Entonces, ¿de qué te sirve libertad si no tienes comida y no sabes ni qué hacer?

Sin embargo, aunque la crisis era notoria, como bien lo dice Lee, algunos factores afectan de forma distinta a 
diferentes personas. ${ }^{19}$ En este caso, la caída del régimen, así como afectó a muchos, a otros terminó por beneficiarlos, como es el caso de aquellos, pocos, que lograron sacar un provecho económico de la crisis. Como lo manifiesta Andrés, un entrevistado, "los que antes hacían parte del mercado negro que siempre existió durante el régimen se vieron beneficiados, no había productos: ellos conseguían, no habían dólares: ellos vendían [...] Los que hacían parte de la burocracia, muchas cosas públicas pasaron a sus manos, ellos también se beneficiaron".

Sin embargo, así como algunos se vieron beneficiados, otros se vieron más perjudicados. La transformación económica, política y social que experimentaron las nacientes naciones independientes causó la pérdida de estatus de algunos grupos de la sociedad, como la que vivieron los académicos e intelectuales. Hay que tener en cuenta que el grupo aquí estudiado hacía parte en general de un grupo de personas con un alto nivel educativo, dedicadas a la academia. Para entender el caso particular de este grupo, vale la pena recordar que durante la consolidación de la URss, dentro de los planes del partido se incluía el adiestramiento de personal sobre todo en ciencias duras.

La educación, la lectura, la cultura y en resumen la preparación intelectual de la población soviética era uno de los pilares del partido. Primero se constituyó una élite intelectual en los países eslavos, mientras en la parte asiática y el sur de

19 Lee, Everett. “A Theory of Migration”. Demography 3.1 (1966): 47-57. Impreso. 
la URSS siguió siendo mayoritariamente menos educada. Ya para los años sesenta se estaban formando élites de personas altamente educadas y calificadas en las diferentes regiones no eslavas. Gracias a los esfuerzos del partido, entre 1979 y 1985 todas las catorce repúblicas no rusas mejoraron sus niveles de educación, incluso de manera más rápida que Rusia, compitiendo con las zonas eslavas. Las poblaciones indígenas también comenzaron a ganar prestigio al desarrollarse profesionalmente y a ser altamente educadas. La educación se convirtió en un valor para los soviéticos y los intelectuales comenzaron a constituirse como una élite, siendo altamente reconocidos y con un alto estatus.

Aunque los académicos eran bien reconocidos y bien remunerados en la época soviética, al desintegrarse la Unión Soviética fueron unos de los que más padecieron el declive en estatus y en ingresos. Nina, quien migró con su padre, expone la crisis de las personas que se dedicaban a la academia: "mi papá siempre ha sido una persona que ha dependido de sueldo, además siempre ha estado en un rango, pues, de vida muy bueno y las universidades no tenían cómo compensar la inflación con la subida del sueldo [...] pues tú buscas la manera de salir, porque este caos".

Por su parte, Igor explica que las personas con un alto nivel educativo como él tenían los salarios más altos que se podían obtener en la época soviética y que desde su desintegración ya no alcanzaban:

yo tenía un salario más o menos equivalente con 2000 dólares [...] yo era profesor titular del más alto nivel y ese 
salario era lo máximo que podía tener cualquier persona [...] Este salario fue muy bueno, pero después, un día usted tenía 500 euros y despertaba y todo vale por tres más, entonces entre un mes el salario transformó en nada. Entonces, pues yo tenía que trabajar en dos universidades [...] entonces empecé a hacer proyectos [...] Trabajaba mucho, de todas maneras el salario no alcanza, cada vez menos y así todos los profesores quedamos pobres.

Además, todos estos cambios terminaron por modificar los valores antes buscados por el régimen soviético, como la intelectualidad anteriormente referida. Como lo hemos mencionado recurrentemente en este texto, el pcs propendía por universalizar la educación y por hacer de los soviéticos una población altamente educada, con un alto capital cultural. Con la apertura económica, el libre mercado y la admisión, en las naciones emergentes, de cuestiones antes prohibidas por el régimen como la música, la televisión y las películas occidentales los valores y costumbres de la juventud terminaron por modificarse. Esto, como lo refiere Thompson, degeneró en una gran crisis, ${ }^{20}$ que se reflejó en parte en una tensión entre generaciones, cuestión que resulta evidente en el relato de Tania, quien vivió el cambio de régimen político en su adolescencia:

Los jóvenes, digamos de los noventa, fuimos muy diferentes de los jóvenes de los años ochenta [...] Se fue perdiendo

20 Thompson, John. “Russia”. 
mucho esa identidad digamos del joven ruso que era un joven intelectual que se la pasaba leyendo en las bibliotecas, se fueron cambiando mucho los intereses de la juventud, ¿no? Porque las películas y todo lo que la información que comenzó a llegar comenzó a llenar la cabeza de los jóvenes de que vivir mejor es, digamos, bailando música. Entonces la gente comenzó a hacer sus peinados y los cantantes rusos comenzaron a cantar pura música occidental, pero con palabras rusas [...] Los profesores, los papás comenzaron a sufrir, porque la gente comenzó a tomar temprano y a hacer todas las cosas como a la ligera y duro. Fue una época de crisis no sólo económica, fue más que todo crisis social muy grande, porque usted ya veía adolescentes [de] quince años borrachos, drogados, tirados en las calles, ¡uuy! Mucha liberación sexual. Fue una locura, de verdad, una locura. Yo creo que eso fue lo que más motivó a mamá para salir, que nosotras termináramos mal.

La situación general de los países soviéticos y particularmente de Rusia y Ucrania no era la mejor ni la que ofrecía la mejor prospección para quienes serían los futuros migrantes. Al parecer, todos coinciden en este punto, como clara y contundentemente lo ejemplifican las siguientes frases: "Lo mejor era salir”; “Tú buscas la manera de salirte de este caos"; "El caos y la incertidumbre eran totales y, pues, ese momento en el que decidimos irnos”; “ ¿Es que ustedes por qué creen que tantos salimos de allá? [...] era situación económica muy verraca”. 
Esta situación era una de las peores que los individuos podían afrontar, la mayoría de los cálculos que pudieran hacer apuntarían a que era mejor salir de aquella situación política, económica y socialmente caótica. Esto, acompañado de la apertura de las fronteras y de una movilización menos controlada, hizo que muchos salieran. Así, con menos obstáculos intervinientes en la migración, como el control de la movilización, y por la gran crisis general que se vivía, se dio una gran migración de las naciones postsoviéticas al resto del mundo. Como bien lo dice David, "antes usted tenía invitación y tenía que pasar primero por partido del municipio, después de gobernación, después de país, entonces tenía que pasar todas esas allá”, pero una vez cae el telón de acero la situación cambió radicalmente, "ahora no tiene que pasar por nadie, tiene invitación, tiene visa, listo, vaya, no hay problema, entonces muchos nos fuimos".

Tal como lo hemos presentado, todos estos problemas sociales, económicos, políticos, étnicos, psicológicos e identitarios fueron grandes fuerzas de expulsión, que terminaron por mezclarse y afectar a las personas de forma sincrónica. No se puede identificar un único factor push que motivara la migración de estos sujetos, sino la fuerza de todos estos factores en conjunto. Contrario a lo planteado por Radnitz, los factores push económicos no pueden explicar por sí solos el deseo de los individuos de salir, ya que los límites entre la crisis económica, social, política, psicológica e identitaria que se vivía a veces parecen no ser muy claros. Debemos ser enfáticos al afirmar que lo que aparentemente puede ser 
leído como una crisis económica, en realidad tiene muchas dimensiones que deben ser elucidadas.

Al ver esta situación, resulta notable que la migración de estos sujetos se deba en gran medida a los factores negativos en sus países de origen, y en la mayoría de los casos a la búsqueda de una mejor situación económica. Sin embargo, hay algunas cuestiones que deben ponerse en consideración. Primero, aunque el gran caos que se vivía en Ucrania y Rusia fue lo que motivó a muchas personas a abandonar el país, cada caso es particular. Así como muchos buscaban la forma de salir, otros que migraron no pensaban hacerlo, su decisión se basó más en un encuentro fortuito o en una oferta laboral que, sumada a la crisis, terminó por motivarlos, como veremos más adelante.

Además, hay que tener en cuenta que la crisis que se presentó después de la desintegración de la Unión Soviética fue apreciada e interiorizada de forma diferente por las personas, dependiendo del momento de su ciclo vital y su rol dentro de la sociedad. Así, por ejemplo Igor, padre de 5 hijos y el mayor proveedor económico de la familia, que se desempeñaba como docente, narra sobre todo la crisis económica, la devaluación de la moneda, la hiperinflación y la inestabilidad laboral, lo que, en conjunto con otros factores, terminó por motivar su salida. Por su lado Tamara, quien vivió este cambio en su adolescencia y dependía económicamente de sus padres, centró su relato en narrar el cambio de los valores dentro de la juventud y los conflictos generacionales que comenzaron a presentarse. Demetrio, quien tenía 10 años cuando sucedió el cambio, cuenta lo agradable que fue para él la llegada de nuevos productos: 
yo me acuerdo que el último año antes de venirme para acá, ehhhh, empezaron todos los cambios de la parte de la Unión Soviética y la transformación de la Rusia actual [...] empezaron a llegar con productos, la gaseosas internacionales, empezaron a llegar los chocolates, las milky way que me gustaban mucho [risas], empezó a llegar el snickers y todo eso. Siempre estaba loco porque me compraran un chocolate de esos.

En segundo lugar, hay que tener en consideración que sólo el hecho de que existiera un contexto expulsor y que las personas experimentaran tan acuciosa situación no explica inmediatamente que las personas hubiesen migrado y lo hubiesen hecho en este caso particular a Colombia, sobre todo tomando en cuenta que Colombia no era el destino más atractivo, como lo exploraremos más adelante. Por esta razón, como lo sugiere Portes, ${ }^{21}$ se hace necesario revisar otros factores como el papel de las redes, el capital social y el capital cultural para entender en su totalidad dicho proceso. Teniendo en cuenta que, aunque existían motivos para la migración y las fuerzas de expulsión fueran notorias, la migración no se concretó en la mayoría de los casos hasta tener una red migratoria. En la siguiente sección entraremos a exponer la intervención de estos factores en la materialización de la migración.

21 Portes, Alejandro. “Contemporary Immigration: Theoretical Perspective on Its Determinants and Modes of Incorporation". The International Migration Review 23.3 (1989): 606-630. Impreso. 


\section{2. ¿Por qué a Colombia?}

A pesar de que el modelo push and pull es un buen marco explicativo, es necesario considerar otras posibles explicaciones que no encajan en este modelo tradicional. No podemos limitar la migración a la movilización de países económicamente menos desarrollados a países económicamente desarrollados, restringiendo la causa de las migraciones a la disparidad económica que existe en el mundo: este enfoque no es el que mejor se adecua a este estudio. Además, como bien lo expone Portes, esta teoría deja de lado las particularidades de las naciones de origen y destino en cada caso, además de ignorar la particularidad de los sujetos que migran, ni explica por qué se dan migraciones dentro de países igualmente pobres. ${ }^{22}$ En concreto, aunque es innegable que el contexto expulsor y los factores estructurales motivaron a los individuos a salir, y que sin la existencia de este contexto tal vez nunca hubiesen migrado, la crisis no tiene suficiente poder explicativo para responder ni cómo se concretó la movilización, ni por qué se dio a Colombia y específicamente a Bucaramanga. Por tanto, debemos buscar otras teorías que sean complementarias para entender otros aspectos de este fenómeno.

En las siguientes líneas nos concentraremos en mirar varios aspectos y varias teorías de suma importancia para entender la situación de los sujetos aquí estudiados, particularmente el papel del capital social, las redes sociales, el capital cultural, el papel de las instituciones y los convenios

22 Ibid. 
entre Ucrania y Rusia con Colombia, para entender a cabalidad por qué estos sujetos migraron y por qué lo hicieron específicamente a nuestro país.

\subsubsection{El capital social y las redes como elementos de atracción}

En el caso de los rusos y ucranianos que se establecieron en la ciudad de Bucaramanga para la década de los noventa, el capital social en relación con la migración se evidencia en distintas etapas y dimensiones del proceso. Los lazos fuertes con miembros de la familia o los construidos por relaciones sentimentales con colombianos resultaron decisivos en los procesos migratorios de algunos de estos sujetos, mientras que en otros casos los lazos débiles fueron los que terminaron por mostrar a Colombia como un destino posible. El capital social y las redes sociales, en ambos casos, son de vital importancia para explicar el proceso, por lo que se hace necesario examinar dichos conceptos.

Desde el siglo xx, el concepto de capital social ha sido usado recurrentemente en los estudios sociales. Sin embargo, aún no hay precisión ni mucho menos convergencia en cuanto a su significado y su aplicación. Como es un elemento central para comprender el caso aquí estudiado, haremos una breve exploración por algunos de los autores más representativos que han usado este concepto dentro de la sociología, para poder explicar qué se ha entendido por capital social y cómo será entendido dentro de este estudio. ${ }^{23}$

23 Valcárcel, Marcel. Aspectos teóricos del Capital Social y elementos para 
Bourdieu, Coleman, Putnam y Granovetter son algunos de los teóricos más sobresalientes que han usado y definido el capital social dentro de la sociología. Para Bourdieu, este es un recurso que los individuos poseen en distintas cantidades, que puede ser acumulado y que puede ser usado para acceder a otros capitales como el económico. ${ }^{24}$ Para este autor, es intercambiable por otro tipo de capital como el cultural o el económico. Por su lado, Coleman sitúa el capital social en la estructura de las relaciones sociales y hace énfasis en su naturaleza colectiva. ${ }^{25}$ Según Coleman, se encuentra en la relación entre los actores, en los lazos interpersonales por los cuales los sujetos logran fines que de otra manera no podrían ser alcanzados. Coleman alude que la cercanía de los lazos facilita la obtención de fines tanto individuales como colectivos. Dentro de las redes sociales, contempla los lazos de parentesco, las redes comunitarias informales y las organizaciones sociales. Bourdieu y Coleman convergen en el punto de que la pertenecía a un grupo y la existencia de redes sociales juegan un papel central en la creación y el mantenimiento del capital social.

su uso en el análisis de la realidad. Lima: Universidad Católica del Perú, 2008. Impreso.

24 Bourdieu, Pierre. "Le capital social, notes provisoires". En Bevort A. y M. Lallement. Le Capital social. Performance, équité et réciprocité. París: La Découverte, 2006. 29-34. Impreso.

25 Coleman, James. "Social Capital in the Creation of Human Capital". The American Journal of Sociology 94, Supplement: Organizations and Institutions: Sociological and Economic Approaches to the Analysis of Social Structure (1988): 95-120. Impreso. 
Putnam parte de Coleman y también sitúa el capital social en las relaciones sociales, aunque se concentra en las formas organizadas de capital social. ${ }^{26}$ Para este autor, es un bien simultáneamente privado y público, pues las acciones dentro de una red tienen efectos fuera de esta. Putnam hace una diferencia entre lazos fuertes y lazos débiles, argumentando que los lazos débiles también son parte esencial para la obtención de ciertos beneficios. Pero es tal vez Granovetter, del cual parte Putnam, el que más desarrolla el tema de la importancia de los lazos débiles dentro de una red egocéntrica. Este autor afirma que en muchos casos son más importantes los lazos débiles que los fuertes en la obtención de beneficios tanto individuales como colectivos, como también para la integración de los individuos dentro de las sociedades. ${ }^{27}$

En este estudio ubicaremos el capital social en los lazos interpersonales. Por tanto, definiremos el capital social, siguiendo la línea de Coleman, como las relaciones que un sujeto tiene con otros y que le permiten conseguir fines que sin él no serían alcanzados. Sin embargo, pondremos en duda el argumento de Coleman de que entre más cercanos sean los lazos, mayores serán los beneficios obtenidos, pues, como es demostrado en los casos aquí estudiados, no siempre los lazos fuertes y las redes densas son las que permiten la realización del proceso migratorio. Destacaremos entonces,

26 Putnam, Robert. Democracies in Flux: The Evolution of Social Capital in Contemporary Society. New York: Oxford University Press, 2004. Impreso.

27 Granovetter, Mark. “The Strength of Weak Ties”. American Journal of Sociology 78. 6 (1973): 1360-1380. Impreso. 
siguiendo la teoría de Granovetter, la importancia de los lazos débiles en la concertación del proyecto migratorio y en el proceso de toma de decisiones. Esto, sin restarle importancia a los lazos fuertes, como las relaciones estrechas de amistad o las relaciones familiares y su valor dentro de estos procesos.

En cuanto a las redes sociales, para nuestros fines analíticos y siendo esta definición la que más se adecua a nuestro caso empírico, primero partimos de Coleman y Granovetter para afirmar que son las relaciones entre agentes las que constituyen la base de las redes sociales. Segundo, nos concentraremos en redes egocéntricas, es decir, donde el sujeto es el centro de la red. Así, siguiendo la línea de Granovetter, entenderemos que una red está compuesta por vínculos fuertes, vínculos débiles y vínculos ausentes. Mientras los vínculos fuertes o lazos fuertes son aquellos que se constituyen con los sujetos con los que el ego interactúa con mayor frecuencia y de forma más intensa, los débiles se crean con sujetos con los que ego no interactúa con frecuencia. Además entenderemos que la red del sujeto no está constituida solamente por los vínculos directos, es decir por los que ego conoce directamente, sino que además existen dentro de la red vínculos indirectos, como los amigos de un conocido, por los cuales ego puede acceder a información distinta a la de su grupo. También contemplaremos dentro de la red la existencia de los vínculos puentes, concepto desarrollado por Granovetter y retomado por Putnam, entendido esto como los vínculos que unen dos redes. 


\subsubsection{Los lazos débiles y su importancia en el proceso migratorio}

En su texto "La fuerza de los vínculos débiles", ${ }^{28}$ Granovetter pone en consideración la idea de Coleman de que los vínculos fuertes son de mayor importancia en las redes egocéntricas de los sujetos que los débiles, y que son estos vínculos los que le permiten al sujeto conseguir ciertos objetivos que en su ausencia serían inalcanzables. ${ }^{29}$ Contrario a Coleman, Granovetter afirma que los vínculos débiles resultan ser de gran importancia, pues gracias a estos logra entrar nueva información a las redes densas, lo que termina por abrirles nuevos horizontes y oportunidades a los sujetos. Además, son los lazos débiles los que entran a servir como puente entre la red egocéntrica del sujeto y otras redes.

Para Granovetter, la existencia de vínculos débiles llega a ser más importante y más útil que la existencia de vínculos fuertes dentro de una red egocéntrica, ya que en una red densa lo más posible es que los vínculos fuertes compartan amigos e información y que sea difícil por tanto encontrar dentro de este grupo nuevos horizontes y oportunidades. Los vínculos débiles, en cambio, pueden aportar nueva información al sujeto, pues tiene acceso a información que su red no posee. Esto lleva a Granovetter a concluir que resulta más importante la cantidad de vínculos débiles, dentro de una red egocéntrica, que la cantidad de vínculos fuertes a la hora de

\footnotetext{
28 Ibid.

29 Coleman, James. "Social”.
} 
acceder a información y encontrar nuevas oportunidades, como oportunidades laborales, por ejemplo. ${ }^{30}$

En muchos de los casos de los rusos y ucranianos que llegaron a Bucaramanga, es clara la importancia de los lazos débiles dentro de las redes egocéntricas que sostenían estos migrantes en sus países de origen. Estos lazos, además de proveer información importante a algunos de los migrantes e influenciar la toma de decisión de estos, terminaron por vincularlos directamente al mercado laboral de la ciudad de Bucaramanga. Veremos cómo estos lazos débiles actúan en el proceso migratorio de estos sujetos.

Al igual que en el estudio hecho por Granovetter, en el caso de algunos de estos migrantes la razón por la cual se presenta Colombia como un posible destino para la migración es un encuentro casual con un antiguo amigo de estudio con quien se ha mantenido un contacto apenas esporádico. Tal es el caso de Ana, quien sale de Ucrania en 1996. El encuentro con un compañero de estudios, con el que no mantenía contacto permanente, además de darle información sobre nuevas oportunidades laborales fuera de Ucrania y de vincularla con la institución en la que trabajaba, la hizo contemplar nuevos horizontes. Como ella lo manifiesta:

A diferencia de pronto de muchos paisanos, no pensaba irme del país por más que eso fue muy drástico, pero salió una oportunidad, como siempre sucede, casualidades, los encuentros casuales muy contrario a lo que uno piensa.

30 Granovetter, Mark. “The Strength”. 
Me encontré con un compañero de estudios que en ese entonces ya vivía en Colombia, cuatro, tres, cuatro años, y él me ofreció que si yo quisiera para aplicar a unos, ehhh, sí, a unos puestos de trabajos en una facultad y me hablo de maestro Santiago. Contemplando la situación que se vivía, decidí presentarme.

En este caso el contacto débil relacionó a Ana con el maestro Santiago, que en aquel entonces buscaba profesores para crear una facultad en una universidad de Bucaramanga, a la cual Ana se vinculó posteriormente. La información que Ana recibió la transmitió a dos de sus lazos fuertes, también músicos, quienes viajaron a Colombia en años posteriores. Por tanto, este encuentro casual con un lazo débil fue el comienzo de una pequeña cadena migratoria. Serger expresa al respecto: "Primero se fue una amiga que se llama Ana, entonces luego me llamaron a mí para que diera clases". Por su lado, Myriam cuenta: “Aquí había un convocatoria y una amiga mía, Ana, pues ya estaba trabajando acá y pues maestro Santiago estaba buscando profesor, entonces ella me escribió, no, me llamó y me dijo que si yo quisiera pasar mi grabación y mis papeles acá para que maestro Santiago los mire, sí, entonces yo hice grabación, ordené todos mis papeles y me aceptaron".

Lo interesante de este caso es que este encuentro casual no solo repercutió en la migración de Ana, sino que este lazo débil dentro de su red egocéntrica se constituyó como un puente para que ella pasara de un sistema de vínculos -el mantenido en Ucrania- a otro sistema de vínculos, el 
existente en Colombia, lo que a su vez la convirtió en un puente en las redes de sus amigos, pasando información que encontraba en el lugar de destino a la red densa que tenía en su país de origen. Este caso nos muestra cómo los lazos débiles traen información, abren oportunidades y nuevos horizontes al sujeto que después transmite esta nueva información a su red afectiva compuesta por lazos fuertes. En este caso, observamos la importancia de los vínculos débiles en cuanto a la difusión de nueva información, que nutre no sólo a ego sino a otras personas de su red más densa.

En el caso de Igor y David, también un lazo débil ayudó a concretar sus migraciones y la posterior migración de sus familias. Estos sujetos, a diferencia del caso anterior, sí estaban buscando la forma de salir del país, por lo que hicieron uso de su capital social para lograr este fin. Igor y David se desempeñaban como profesores de pregrado y posgrado de la Universidad Patricio Lumumba de Moscú. Después de la caída del régimen, enviaron hojas de vida con sus estudiantes extranjeros que volvían a sus países de origen -por la crisis que se vivía en Rusia-, para que las llevaran a las universidades en sus países, con el fin de recibir una propuesta laboral concreta que les permitiera salir de Rusia. Gracias a estos vínculos débiles, en los dos casos llegó una invitación para ir a Bucaramanga a trabajar como profesores en la Universidad X. En este caso, como bien lo manifiesta Granovetter, desde el punto de vista de los individuos los vínculos débiles son un importante recurso para hacer posible la oportunidad de conseguir objetivos que sin ellos no serían posibles. Como lo refiere Igor: "Lo mejor era salir. Hablé con algunos estudiantes 
que se llevaran mi hoja de vida para donde vivieran, el primer país que mandó invitación fue de Bucaramanga”.

Como se observa en la anterior narración, aunque el contexto expulsor que se tornaba cada vez más difícil hizo concluir a estos sujetos que lo mejor era abandonar el país, fue solo a través del uso del capital social que esta movilización se materializó. De nuevo gracias a la intervención de un lazo débil.

A diferencia del caso de Ana, este vínculo débil no relacionó a David e Igor a otros sujetos, sino que los vinculó con una institución en el país de destino. Estos lazos débiles que se limitaron a pasar hojas de vida terminaron insertando a estos sujetos en el mercado laboral regional. En los casos de Igor, Ana, Myriam y Serger la intervención del lazo débil dentro de la red concluyó también con la obtención de trabajo en la ciudad de Bucaramanga y en la posterior migración de miembros de sus familias.

\subsubsection{La reunificación familiar}

Algo que aún no se ha mencionado es la llegada de más migrantes producto de la reunificación familiar. En varios de los casos anteriormente mencionados, se ve cómo la migración de estos sujetos produce la posterior migración de otros miembros de su familia. En estos casos, la reunificación familiar se convierte en una meta para el migrante, quien enfoca todos sus esfuerzos de los primeros años en el país de acogida en traer a sus familiares. Como narra Igor: "Yo no comía na$\mathrm{da}$, no compraba nada, para poder ahorrar para sus pasajes y para arrendar un apartamentico para ellos". En el caso de 
Igor, la migración de este sujeto supuso la migración de su familia, constituida por su esposa y cuatro hijos, a los dos años siguientes. En este caso, la presencia de un vínculo débil dentro de la red egocéntrica de Igor terminó por determinar la migración de seis de sus vínculos fuertes, miembros de una misma familia. Ana también trajo posteriormente a su hijo y David a su esposa. Hay que tener claro que la migración de miembros de una misma familia hace parte de la migración por vínculos fuertes, pues tal como lo expone Coleman, la familia es una red densa conformada por vínculos fuertes. ${ }^{31}$

Resulta innegable la importancia de los lazos débiles dentro de las redes egocéntricas de estos sujetos. Es gracias a estos lazos débiles -quienes transmiten nueva información a redes más densas y abren oportunidades laborales a estos migrantes- que se concreta la inmigración de 13 sujetos provenientes de Rusia y Ucrania a Bucaramanga y que se comienzan pequeñas cadenas migratorias. No obstante, hace falta contemplar qué papel jugaron los lazos fuertes en la migración de otros sujetos ahora establecidos en la ciudad, por lo cual se hace necesario indagar qué tan cierto es que en una red sea más importante la cantidad de lazos débiles que los lazos fuertes.

\subsubsection{Los lazos fuertes y su importancia en el proceso migratorio}

Aunque en los casos anteriores los lazos débiles son los que terminaron por abrirles nuevas oportunidades a algunos

31 Coleman, James. “Social”. 
migrantes que llegaron a Bucaramanga, esto no quiere decir que los lazos fuertes no puedan crear puentes entre redes. Como tampoco podemos deducir que los lazos fuertes no incorporen nueva información a los sujetos de una red densa, ni ofrezcan nuevas oportunidades y horizontes a sus vínculos más cercanos.

Granovetter afirma que los lazos fuertes no pueden constituirse como puentes entre redes y por tanto no son de mayor importancia a la hora de trasmitir información. ${ }^{32} \mathrm{~A}$ diferencia de lo que argumenta Granovetter, creemos que un lazo fuerte dentro de dos redes puede ser un vínculo puente dentro de estas, sobre todo en el caso de los migrantes. Un migrante puede pasar nueva información y presentar nuevas oportunidades y horizontes a los miembros de su red densa en el país que reside, obtenida del conocimiento e información que tiene gracias a los vínculos que conserva en su país de origen, convirtiéndose en un puente entre dos redes densas a las cuales pertenece. Tal es el caso de algunos sujetos que salieron de Rusia o Ucrania, gracias a vínculos muy fuertes con amigos cercanos colombianos o gracias a relaciones sentimentales con colombianos que vivían en las naciones postsoviéticas.

Lina es un ejemplo de aquellas personas que migraron gracias a sus vínculos fuertes con colombianos. Ella migró para finales de la perestroika, en 1990, con su esposo colombiano. Lina no conocía Colombia, ni a los familiares y amigos de su esposo. La explicación de la migración de Lina

32 Granovetter, Mark. "The Strength”. 
podría reducirse a decir que fue producto de una alianza matrimonial y a un común acuerdo entre la pareja. Sin embargo, Lina y otras mujeres que llegaron en la época casadas con colombianos no se movilizaron por el simple hecho de haber contraído matrimonio con un colombiano; esta posibilidad comenzó a ser contemplada sólo en el momento en que sus países entraron en declive. Como lo narra Lina: "Como mi esposo colombiano [...] él decía que aquí hay como más opciones, posibilidades y pues sí, entonces la idea era venir aquí y buscar trabajo, y todo eso".

De igual manera sucedió con otras mujeres, casadas con personas de la región, que llegaron al país. Su motivación para viajar a Colombia se fundamentó sobre todo en el hecho de que su pareja era de este lugar. En estos casos, el papel que cumplieron los lazos fuertes dentro de la red de los sujetos no se limitó a la transferencia de información nueva o a que se hayan presentado nuevas oportunidades u horizontes laborales a los futuros migrantes. El vínculo fuerte con un colombiano, además de abrir nuevos horizontes y permitir la entrada de estos sujetos al mercado laboral del país receptor, facilitó y aceleró la salida de los migrantes del país, reduciendo los costos de la movilización. Además, estos vínculos fueron los que posteriormente se constituyeron en elementos claves en la socialización y asimilación del nuevo inmigrante en el país de acogida. Como dice Lina:

Pasó la crisis, yo quería ir a Colombia pero subió mucho el dólar y yo no podía comprar pasajes. Yo viajé en un avión que mandó el gobierno de Colombia para rescatar a los 
últimos estudiantes allá colombianos, que ya como que se cayó todo el sistema, ya no querían seguir. Me llevaron por estar casada con colombiano. Creo que el pasaje me valió quinientos dólares, por quinientos dólares nos llevaron directamente a Cali sin ningunas escalas.

El caso de Olga también muestra cómo sus lazos fuertes fueron los que la ayudaron a movilizarse a Colombia en 1990, antes de que se desintegrara la Unión Soviética. Una familiar suya, que había viajado años antes a Colombia con un colombiano con el que se casó, la animó a migrar a Colombia y ella ya decidida se casó con un amigo colombiano con el fin de facilitar su salida de Rusia. Aquí vemos también cómo los lazos fuertes actúan no sólo en la toma de decisión, sino que también terminan por facilitar su salida, como en el caso de Lina.

Aquí hay que tener en cuenta que la migración de rusos y ucranianos que se establecieron en Bucaramanga no llegó producto de una sola red. Por el contrario, fueron múltiples las redes por las que llegaron, redes que como vimos incluían un número reducido de sujetos. No existía una red de apoyo consolidada, porque se trataba de una migración nueva. No eran muchos los rusos o ucranianos que se hallaran establecidos hace un tiempo considerable en la ciudad de Bucaramanga cuando comenzaron a llegar estos sujetos. Por tanto, era difícil la existencia de redes grandes de migración. Aunque el capital social fue de vital importancia para materializar la migración en este caso, la existencia de redes de paisanos preexistentes en el país de destino no constituyó la base ni 
la causa del proyecto migratorio -estas no existían. Además, hay que tener en cuenta que este flujo migratorio tampoco ha perdurado, por el contrario, en los últimos años muchas de las personas que se encontraban establecidas en la ciudad han retornado a sus países de origen o han migrado a otros países de Europa, principalmente porque no se integraron satisfactoriamente a la ciudad. Este punto lo discutiremos con mayor profundidad en el tercer capítulo.

Como se ha expuesto a lo largo de este texto, las relaciones sociales que tiene una persona constituyen su capital social. Este capital social, la base de sus redes egocéntricas, tiene un papel decisivo en la migración de estos sujetos que, ya fuera por lazos débiles o fuertes, comenzaron a contemplar a Colombia como un destino para su migración. En el caso de los lazos débiles, la decisión se toma más por las oportunidades laborales concretas que se le presentan al futuro migrante en el país de destino, mientras que en el caso de los lazos fuertes esta decisión está más ligada al vínculo que se tiene con la persona de la región o las reagrupaciones familiares. No obstante, en ambos casos la decisión de migrar se halla fundamentada en la situación acuciosa que se vivía en sus países de origen.

Valga concluir aseverando que en este estudio, en algunos casos parece más importante el papel de los lazos débiles dentro de la red y en otros la función que ejercen los vínculos fuertes en presentar Colombia como destino. Por tanto, no podemos asegurar, según como lo manifiesta Granovetter, que sea más importante tener vínculos débiles dentro de una red egocéntrica, ni tampoco podemos asegurar, como 
manifiesta Coleman, que entre más densa sea la red y más vínculos fuertes se encuentren dentro de ella, más ventajas tienen los sujetos con relación a aquellos que más vínculos débiles ostentan. Por el contrario, vemos cómo en el caso de la migración de estos sujetos, tanto los vínculos débiles como los fuertes pueden ser portadores de nueva información y pueden resultar determinantes en el momento de tomar la decisión de migrar a Colombia y, como veremos más adelante, en el de la integración de los sujetos. Creemos que es necesario tanto el estudio de los lazos débiles como el estudio de los lazos fuertes dentro de las redes sociales, pues, como se ha visto, el capital social que detentan los sujetos, ya sea expresado en lazos débiles o fuertes, puede resultar determinante a la hora de migrar. Como ya lo hemos mencionado, el hecho de que los migrantes aquí estudiados hubieran podido salir se debió en parte a su capital social, pero también es menester examinar el papel del capital cultural en este proceso. Gracias a este, algunos obtuvieron propuestas concretas de trabajo en el país receptor, lo que permitió su posterior migración.

\subsubsection{El capital cultural y la inserción laboral}

Al referirnos a capital cultural es necesario mencionar a Pierre Bourdieu y su definición de este concepto, para posteriormente entender cómo este tipo de capital permite a los inmigrantes integrarse a la sociedad receptora y asimilar la nueva cultura que les es presentada. Para Bourdieu, el capital cultural significa la acumulación de conocimientos que se adquieren a través de la formación académica, la experiencia 
profesional, los conocimientos específicos que detentan los sujetos, los conocimientos heredados y, en sí, todo tipo de actividad que represente al sujeto la apropiación de material intelectual. ${ }^{33}$ En el caso aquí específico, es evidente que el capital cultural de los sujetos fue adquirido no solo gracias a los estudios realizados, sino además al interior de la familia y reproducido y nutrido por el régimen soviético. Como bien lo narra Demetrio, “mi papá siempre nos ponía a leer y a estudiar matemáticas, poesía, hasta psicología [risas]”, y como agrega Igor, "el partido siempre daba una hora al día para dedicar a la lectura con hijos. Esto es bueno porque aprendía en casa y además en escuela. Aquí no, aquí solo aprende en escuela, es por eso que no aprenden mucho". Por último hay que añadir que, como manifiesta Bourdieu, la acumulación de este material permite al sujeto moverse dentro del espacio social y alcanzar objetivos que sin este no serían posibles. ${ }^{34}$

Ya teniendo claro lo que es entendido por capital cultural, empezaremos por decir, como habíamos mencionado en la caracterización de nuestra población, que la totalidad de los sujetos que migraron en edades adultas a Colombia tenían una alta formación académica. Todos llegaron al país siendo profesionales y la gran mayoría con estudios de posgrado. Lina llegó con un magister y un $\mathrm{PhD}$ en ciencias físico-matemáticas, Igor con magister y doctorado en física y postdoctorado en física química. David llegó con un magister y

33 Bourdieu, Pierre. Capital cultural, escuela y espacio social. Madrid: Siglo XXI Editores, 1997.

34 Ibid. 
posgrado en física, Ángela con un $\mathrm{PhD}$ en historia, solo por citar algunos de los casos. Como uno de los principios del gobierno soviético era educar a la población, se había hecho un gran esfuerzo por incentivar la formación académica dentro de las naciones soviéticas, por lo que el acceso a la educación y el porcentaje de personas con alto capital cultural era elevado. En contraposición, en Colombia, según lo registran los censos, para 1993 sólo el 0,8 \% de la población colombiana tenía estudios de posgrado y en años anteriores el número era mucho más bajo. ${ }^{35}$

Por tanto, aunque es cierto que el papel de los lazos es importante en la concertación del proceso migratorio, el hecho de que estos sujetos llegaran con ofertas laborales concretas a Colombia se debió, además de sus vínculos, a su alto capital cultural en comparación con el de la población local. En el caso de Igor, por ejemplo, el contexto expulsor avivó su deseo de salir de Rusia, luego, gracias a un lazo débil, su hoja de vida llegó a una universidad en Colombia que decidió contratarlo. Pero, que este sujeto concretara la obtención de este empleo, y por tanto la posibilidad de salir del país, no se debió sólo al papel del lazo débil en este proceso, sino a su alto capital cultural. Este sujeto, además de que poseía un alto nivel educativo, ya contaba con una vasta experiencia docente e investigativa en sus años de trabajo en la Universidad Patricio Lumumba de Moscú, lo cual

35 Colombia, Departamento Nacional de Estadística. Reporte censo general 1993. Bogotá: DANE, 2004. Impreso. 
aumentaba su capital cultural y lo hacía muy atractivo para la institución colombiana.

En el caso de los ucranianos que llegaron a conformar la facultad, aunque también por un lazo débil accedieron a la información y a las oportunidades laborales, y aunque también este lazo terminó por referirlos, fue gracias a que su capital cultural era más alto que el de los locales que consiguieron el empleo. Como lo refieren sus narraciones, la formación musical de estos personajes difería mucho de la formación musical de los locales, siendo la segunda mucho menos rigurosa. Al referirse a la formación musical en Colombia, y en particular en Bucaramanga, y al compararla con la de su país, Myriam asevera: "El nivel es mucho más bajo porque no hay algo estricto, por ejemplo allá tenemos 8 años de preparación [...] lo que ven aquí los jóvenes en el pregrado de música, allá lo ven los niños en las escuelas primarias y esa es mucha diferencia”. Por su lado, Serger narra:

Desde los 5 años y 7 años ya estudiaba música, desde bien chiquito, cosa que no hay aquí solo por deseo de los padres [...] De estos 7, 5 años uno entra ya presentando por examen de admisión al instituto de música, la carrera dura 4 años, después de eso vienen otros 5 años en el conservatorio, también examen de admisión, sólo los mejores entran y, bueno, eso fue lo que yo hice, 14 años de estudios musicales.

David es otro ejemplo, gracias a su alto capital cultural este sujeto fue aceptado por la universidad X como profesor 
titular antes de su migración. Ángela, quien vino con su esposo, también llegó con un trabajo asegurado en la Facultad de Historia, donde había para entonces una vacante para profesor titular a la cual ella accedió gracias a su alta formación académica.

Sin embargo, hay que tener en cuenta que la decisión de migrar se basó tanto en el capital social como en el cultural. La influencia que tuvieron cada uno de estos capitales en la decisión de movilizarse se vinculó con la densidad de los lazos. Por ejemplo, en el caso de lazos muy fuertes con colombianos, la decisión de migrar específicamente a Colombia se fundamentó más en el capital social que en las oportunidades laborales concretas; así fueron los casos de Sabrina, Lina, Olga e Isabela, quienes llegaron sin trabajo fijo. Aun así, Colombia resultaba atractivo por el vínculo fuerte que tenían con una persona con nacionalidad de este país. Ángela, por ejemplo, llegó con un trabajo fijo, que consiguió gracias a su esposo. Este había viajado primero a Colombia y arreglado todo para su llegada. Así pues, la decisión de viajar a Colombia se tomó antes de tener un trabajo asegurado. En los casos en los que Colombia se presentó como un destino posible por la información dada por un vínculo débil, el papel del lazo débil quedó en este plano y lo que hizo atractiva a Colombia, más que el capital social con personas en el país receptor, fueron las oportunidades laborales que se materializaron. Es de resaltar que aunque algunas de las personas que llegaron casadas no tenían un trabajo asegurado, entraron al mundo laboral local en poco tiempo gracias a su alto capital 
cultural, tema que retomaremos en el siguiente capítulo al tratar el tema de la integración.

\subsubsection{El papel de las instituciones y los convenios internacionales en el proceso migratorio}

Entre el proceso migratorio y el papel del capital cultural y social, falta mencionar el papel de las instituciones en el proceso migratorio y los convenios y contactos que existían entre la URss y Colombia, previos a la migración de estos sujetos. Cuestiones que pueden ayudarnos a explicar por qué la migración aquí estudiada se presenta a Colombia y específicamente a Bucaramanga.

Como bien lo manifiesta Portes, los comienzos de los flujos migratorios no se dan simplemente por las comparaciones individuales sobre las ventajas económicas, sino por la historia o el contacto previo entre sociedades de origen y destino de los migrantes. ${ }^{36}$ En este caso particular esta aseveración puede indicarnos por qué la migración de estos individuos se da específicamente a la ciudad de Bucaramanga, sin que existiera una migración de antaño a la región ni redes consolidadas de personas provenientes de estas nacionalidades en la ciudad receptora, además de no ser un lugar con una economía muy estable. Por lo tanto, resulta importante detenernos a examinar las relaciones que existían entre Colombia y la uRss para la época para entender a cabalidad por qué esta migración se da a esta región en específico.

36 Portes, Alejandro. “Contemporary”. 
Aunque puede resultar obvio que la causa por la cual esta migración se da a Colombia, y en particular a Bucaramanga, es que en la red de estos inmigrantes existía algún vínculo con alguien que vivía en esta región o que era nativo de ella, esta explicación, aunque obvia, deja en el vacío por qué razón estos sujetos mantenían vínculos con colombianos o con paisanos que ya estaban establecidos en este país.

Una respuesta es que desde los años cincuenta hasta la desintegración de la Unión Soviética, la uRss ofrecía becas a jóvenes colombianos. Como bien está registrado en la Embajada de la Federación de Rusia en Colombia, "Desde los años 50, jóvenes colombianos cursaron estudios en centros docentes de la Unión Soviética, proceso que se hizo más intenso y sistemático con la fundación en Moscú, en el año 1960, de la Universidad de Amistad de los Pueblos Patricio Lumumba, creada expresa y exclusivamente para proporcionar estudios superiores a jóvenes procedentes de los países en vías de desarrollo, de Asia, África y América Latina”. ${ }^{37}$ En esta universidad laboraban como profesores David y Serger y estudiaron Isabela, Lina, Anastasia y Olga.

Según cifras estimadas por la Embajada de la Federación de Rusia en Colombia, más de 10000 colombianos cursaron sus estudios en Rusia cuando aún pertenecía a la Unión Soviética. Los estudiantes, que eran escogidos por el Icetex o que ganaban becas a través de organizaciones amigas de la Unión Soviética, terminaron viajando a los países soviéticos

37 Rusia, Embajada de la Federación de Rusia en la República de Colombia. Relaciones ruso-colombianas: una ojeada a la bistoria. Internet. 6 nov. 2014. 
a realizar sus estudios, la mayoría en universidades de la zona eslava, a precios muy bajos, porque contaban con el subsidio del gobierno soviético. Por esta razón, cuando se desintegró la nación de repúblicas socialistas soviéticas, en 1991, 813 colombianos se encontraban en la URss cursando sus estudios. ${ }^{38}$ Como puede deducirse, los vínculos que se tejieron se debieron a una migración anterior de colombianos a la Unión Soviética, gracias a los convenios para estudiar que existían entre las dos naciones.

Aunque las relaciones gubernamentales con países soviéticos se rompieron en Colombia a partir de 1948 a raíz del "bogotazo", y se reanudaron aproximadamente 20 años después, la confederación de naciones soviéticas siempre tuvo dentro de sus intereses crear vínculos con América Latina; para 1959 creó la Asociación Soviética de Amistad y Cooperación Cultural con los Países de América Latina, una institución no gubernamental que buscaba fortalecer las relaciones y el intercambio cultural entre países latinoamericanos y la uRss. ${ }^{39}$ Gracias a esta asociación, para la época comenzaron a crearse casas de la amistad y la solidaridad con los países soviéticos en distintos países de América latina.

Para el caso particular de los ciudadanos bumangueses que estaban en la URss haciendo sus estudios, debemos referirnos al hecho de que en Bucaramanga se instaurara la Casa de la Amistad con los Países Socialistas, una institución que

38 Mejía, Adolfo. México y la Unión Soviética en la defensa de la paz. México D. F.: Agencia de prensa Nósvoti, 1986.

39 Ibid. 
funcionó en esta ciudad hasta principios de los años noventa. ${ }^{40}$ Aunque no se encontró información histórica sobre esta institución, la describiremos a partir de los relatos recogidos. La Casa de la Amistad con los Países Socialistas funcionó en Bucaramanga en la década de los ochenta y parte de los noventa. Esta institución, además de ofrecer información sobre la Unión Soviética y cursos de ruso, ayudaba a las personas de la ciudad a conseguir becas para hacer sus estudios de pregrado y posgrado en países soviéticos; también les ayudaba en todo su proceso migratorio, ofreciéndoles información sobre vivienda, etc. Además, en esta institución se difundían los ideales y principios de la Federación de Repúblicas Socialistas. Gracias a las becas y asesoría que ofreció esta institución, muchas personas del departamento viajaron a las distintas repúblicas soviéticas a realizar sus estudios. Algunos de estos migrantes se quedaron en estos países, otros volvieron al acabar sus estudios y, gracias al capital cultural que acumularon en estas naciones, se insertaron en puestos altos dentro de la región. Como lo narra Andrés, bumangués que realizó sus estudios en Moscú en los años ochenta y volvió casado con Olga, "muchos nos fuimos a estudiar, pero muchos otros se fueron atraídos por los ideales socialistas,

40 Según los relatos recogidos, la Casa de la Amistad con los Países Socialistas fue clausurada al creerse que en ella se hacían reuniones de frentes de las FARC. Como lo señala el periódico elfrente.com, de la ciudad de Bucaramanga, se presume que en esa institución comenzaron a darse reuniones de altos cabecillas de las Farc como Alfonso Cano, Simón Trinidad y Juan F. Gualdrón, lo cual, podría ser solo un mito pero concluyó con su clausura definitiva. Véase elfrente.com.co. Cano perdió la guerra. 2010. Internet. 5 nov. 2011. 
fuimos muchos los que viajamos, algunos se quedaron, no supimos más de ellos. La mayoría volvimos, muchos casados con rusas y la mayoría ya nos separamos [risas]".

El hecho de que varias personas de la región se hubiesen formado en países soviéticos, además de explicar los vínculos de estos migrantes con colombianos, también explica la inserción y aceptación de dichos sujetos en las universidades locales. Pues, además del alto capital cultural que ostentaban los migrantes soviéticos, también hay que tener en cuenta que mucha gente de la región que había realizado sus estudios en Rusia volvió y se vinculó con las universidades locales, trayendo un gran capital cultural y divulgando la alta calidad de la educación que se daba en las repúblicas soviéticas. Tal fue el caso del maestro Santiago, aquí referido, quien creó la Facultad de Música en una universidad de Bucaramanga, donde en la actualidad laboran 6 ucranianos. Él se formó en San Petersburgo, donde conoció al compañero de estudios de Ana, Serger, y a Myriam, por quien estos sujetos terminaron en Bucaramanga. Al haber estudiado en la Unión Soviética, el maestro Santiago conoció la calidad de la formación musical, por lo que prefería contratar extranjeros, como bien lo refiere Serger:

Un amigo que vivió en San Petersburgo con un colombiano y se graduaron juntos lo invitó a Popayán, allá trabajó 5 años y después aquí maestro Santiago empezó a formar la facultad, como conocía bien el sistema de educación musical en Europa, porque vivió allá mucho y trabajó y estudió [...] entonces empezó a buscar la gente extranjera 
porque aquí [Colombia] hay mucho talento, pero no había un sistema educativo tan bueno y empezó con esto y aquí estamos varios y habían muchos más que ya se fueron.

En la Universidad X muchos de sus docentes también habían sido formados en Rusia gracias a las becas otorgadas. En la Facultad de Física a la que se integraron David e Igor al momento de su llegada había docentes que se habían formado en Rusia. Estos fueron los encargados de recibir y ayudar a estos inmigrantes los primeros días. Como cuenta Igor: "Allá en la Universidad somos varios rusos, en facultad dos, en química dos, en $\mathrm{X}$ una, somos 5 rusos en la Universidad, ya conocían la formación rusa porque hay muchos profesores colombianos que ingresaron de nuestra universidad, como 10 o 15, tal vez un poquito más, pero hay bastantes profesor que estudió en Rusia”.

El hecho de que llegaran algunas mujeres rusas y ucranianas casadas con colombianos a establecerse en Bucaramanga también es producto de las migraciones de colombianos, por motivos académicos, a la uRss. Tales son los casos de Isabela, Ángela, Lina y Olga, quienes llegaron casadas, con sujetos que habían realizados sus estudios en países soviéticos gracias a las becas ofrecidas por la Casa de la Solidaridad con los Países Socialistas. Hay que tener en cuenta que muchas de los migrantes que llegaron a Bucaramanga eran mujeres casadas con colombianos. Esto puede ser explicado, pues, como lo refieren los relatos, muchas de las personas que viajaban a la URSS a estudiar eran hombres. Así pues, la existencia de la Casa de la Amistad con los Países Socialistas y de las becas 
otorgadas por esta institución para ir a la URss puede explicar la posterior llegada de este grupo de migrantes a la ciudad de Bucaramanga, específicamente.

Pero, además, es necesario referirnos a algunas instituciones que fueron esenciales para la materialización de la migración de estos inmigrantes. Las universidades, a las cuales estos sujetos se vincularon antes de migrar, fueron de gran ayuda para el migrante con sus trámites y obtención de permisos para llegar a trabajar al país. También, como veremos más adelante, fueron estas instituciones las que los apoyaron en los primeros días en el país, enviando personas que hablaran el idioma para recibirlos y consiguiéndoles un lugar temporal para la instalación.

La Organización Internacional para las Migraciones (OIM) también resultó relevante en el proceso migratorio de algunos de los sujetos que salieron durante la posperestroika, pues la comunicación entre estos sujetos y las instituciones educativas a las que llegarían eran dificultosas, tanto por problemas en las plataformas de telecomunicaciones como por el tiempo que tomaban los trámites. Como hemos señalado, la situación económica de los sujetos en aquel entonces era bastante difícil. La oIm también terminó por ofrecer apoyo económico a los migrantes para que lograran la salida del país mediante subsidios para los gastos de transporte. Sin la intervención de esta institución y de las universidades es probable que algunos proyectos migratorios hubiesen terminado por no realizarse.

Para seguir la continuidad de uno de los casos nos referiremos a Igor, quien gracias a la oIm recibió su contrato para 
trabajar en Bucaramanga y logró comprar sus tiquetes. Además, posteriormente, recibió ayuda de esta misma institución para lograr reunir a su familia en Colombia: "orm me ayudó un poco, $30 \%$, para los pasajes de mi familia”. Con este caso vemos cómo fue la intervención de varios factores y actores los que determinaron la migración, que no se explica sólo por la difícil situación que se vivía en las repúblicas postsoviéticas, ni sólo por los vínculos que poseían los sujetos, o por su capital cultural, sino que son muchos los elementos que actúan en conjunto para que la migración se realice.

En conclusión, es difícil encontrar un único factor para explicar la migración a Colombia, siendo un fenómeno multicausal. En realidad se trató de un conjunto de factores que se interrelacionaron y afectaron mutua y sincrónicamente, a decir, en este caso, la migración estuvo motivada por factores económicos, políticos, redes sociales, lazos sentimentales, ayudas institucionales, entre otras. La migración no se explica sólo por las decisiones individuales hechas por los actores, ni como el simple resultado de factores sociales o políticos, o sólo por el capital social y cultural que los actores ostentaban, sino como el resultado de todos estos factores en conjunto.

Hasta este punto hemos contemplado cómo la migración a Colombia se materializó, producto de diversos factores. Sin embargo, aún no hemos contemplado qué pensamientos e ideas tenían estos migrantes en torno a Colombia y qué tan atractivo resultaba, más allá de las propuestas laborales y los vínculos con colombianos. Por tanto, resulta necesario ahondar en las ideas previas que los sujetos tenían antes de producirse la migración. 


\section{3. "Nunca imaginé que fuera a vivir en Colombia”. Imaginarios sobre el destino}

En los procesos migratorios se construyen ideas en torno a la movilización, ideas sobre lo que podrá ser encontrado en el lugar de destino: creencias, prejuicios, esperanzas de los individuos que migran, o sea, sus imaginarios. De acuerdo con Lee, en el proceso migratorio "hay marcados elementos de ignorancia o de misterio sobre el lugar de destino y existe siempre incertidumbre con respecto a la recepción del migrante", ${ }^{41}$ esto es lo que da pie a la especulación y a la creación de dichos imaginarios.

Como muchos otros conceptos en torno a la migración, el concepto de imaginario es ampliamente usado en ciencias sociales. Sin embargo, no existe una definición unificada del término. Una definición que podría resultar útil es la de García Canclini, ${ }^{42}$ quien define el imaginario como una construcción colectiva sobre un asunto o hecho en específico, una representación figurada de un aspecto de la realidad: "las imágenes diferenciadas de lo empíricamente observable". ${ }^{43}$ Gilbert Durand, por su lado, define el imaginario como "el conjunto de imágenes mentales, mediante las cuales el individuo, la sociedad y, en general, el ser humano organiza y expresa simbólicamente su relación con el entorno". ${ }^{4}$

\footnotetext{
41 Lee, Everett. “A Theory”.

42 García Canclini, Néstor. Imaginarios Urbanos. Buenos Aires: Eudeba, 1997. Impreso.

43 Ibid.

44 Durand, Gilbert. La imaginación simbólica. Buenos Aires: Amorrortu editores, 2007. Impreso.
} 
Una definición sintética de lo que podríamos considerar como imaginario puede ser la de una construcción colectiva, ajustada mutuamente, hasta cierto punto compartida -no totalmente-, creada a partir de información imperfecta y fragmentada. En este caso, la parte de la realidad que se simboliza es aquella concerniente a la migración y específicamente a la idea de migrar y de lo que se podrá encontrar en el destino. Estas ideas son imaginarias en el sentido de que son representaciones. Por último, debemos aclarar que es compartida, no en el sentido de que las personas llegasen a un acuerdo común, porque en realidad la mayoría no se conocía entre sí, sino que, por decirlo en palabras sencillas, llegaron a las mismas construcciones por caminos diferentes, ya que tenían acceso a informaciones similares dadas por los medios de comunicación y por algunas personas en sus redes sociales. Sin embargo, resulta evidente que los imaginarios que construyeron estos sujetos se debieron también a su capital social. En el caso de las personas que tenían dentro de su red egocéntrica un vínculo fuerte con un colombiano, se construyeron sus imaginarios de forma distinta a aquellos que no tenían información de primera mano sobre el país.

En esta sección argumentaremos dos cuestiones: primero, que los lazos débiles y, especialmente, los fuertes, son muy importantes en la construcción de los imaginarios, así como los medios de comunicación; y segundo, que el grado de incertidumbre que las personas experimentaron dependía también de la fuente de información. Los lazos fuertes, por ejemplo, disminuyeron los niveles de incertidumbre al proveer más completa y confiable información. 
Antes de continuar es ineludible hacer algunas precisiones. Como reiterativamente hemos afirmado, las percepciones y los procesos, aunque tienen elementos comunes, presentan particularidades que hay que resaltar. Para este caso examinaremos la construcción de los imaginarios en relación con los tipos de vínculos que tenían los individuos. En las anteriores secciones vimos cómo la situación social, política y económica de las ex repúblicas soviéticas en las últimas décadas del siglo xx configuraba un ambiente cuando menos insoportable para algunas personas que, a la larga, fueron quienes decidieron migrar. Aunque de hecho había razones de peso para considerar que las ex repúblicas soviéticas y las postsoviéticas no podrían ofrecer un buen futuro, es decir, aunque era claro que había bastantes factores que apuntaban hacia la expulsión, no era claro que Colombia fuese un lugar atractivo, de hecho la idea dominante era contraria.

Los imaginarios que se construyeron en torno a la idea de la migración parecen ser importantes sobre todo en el momento en que se da la toma de decisiones respecto a dejar el país, porque pueden incentivar o desincentivar el deseo de migrar hacia Colombia. Lo que hemos hallado es que la mayoría de las veces los imaginarios surgieron como obstáculos intervinientes, pero el resultado paradójicamente se resolvió a favor de la movilización.

En primera instancia, lo que predominaba era el desconocimiento en un sentido doble: primero, esto se refiere a la inexistencia de la probabilidad de movilizarse hacia Colombia, menos aún hacia Bucaramanga, y segundo, a lo que podría encontrarse en Colombia. La etapa de desconocimiento 
solo fue superada una vez las personas entraron en contacto con sus vínculos, débiles o fuertes, quienes presentaron la posibilidad de desplazarse, inaugurando para los individuos la idea y la posibilidad de migrar a Colombia, tal como sucedió con David, Igor, Serger, Myriam, Ana, Tania, Sandra, Nina y Demetrio. Las frases que resumen este punto son breves: "No sabía nada-al principio-, sólo escuchaba lo que la gente me decía de Colombia"; "Yo no tenía miedo de nada [...] porque no sabía nada”.

Una vez entraron en contacto con sus vínculos, que presentaron Colombia como un destino, se informaron sobre el país por los medios de comunicación. Básicamente lo que aconteció fue que no percibieron a Colombia como la opción óptima para desarrollar sus vidas, sino como un lugar ligeramente más estable. Sin embargo, lo que en general puede apreciarse en sus relatos es el profundo sentimiento de incertidumbre, que tenían antes de la migración, sobre lo que podrían encontrarse al atravesar el océano Atlántico: "Yo iba, no sabía ni por cuanto tiempo, o sea, no, no imaginaba, no sabía nada de Colombia nada, sí”.

El desconocimiento en gran parte fue causado por el hermetismo, producto de la cortina de hierro y la Guerra Fría, que no permitía la llegada de información. Hasta el Glasnost la difusión mediática de información era restringida y controlada. Esta prohibición y restricción de la difusión de información, más la incapacidad de los medios de brindar información veraz, acrecentaron el hecho de que los imaginarios se construyeran sobre ideas la mayoría de las veces distorsionadas. Como bien lo refiere Tania: 
"En ese entonces había mucho desconocimiento [...] Un poco de frontera muy cerrada, no divulgaban mucho la cultura digamos capitalista". Nina también hace referencia a este desconocimiento: "En el colegio no le cuentan a uno mucho, de la cultura latinoamericana hay mucho desconocimiento".

Gran parte del conocimiento que las personas tenían sobre el que sería su país receptor no iba más allá de las cuestiones más emblemáticas, representativas y comunes difundidas mediáticamente, donde el país era visto como una nación subdesarrollada, agrícola y violenta. En este sentido, a pesar de que los medios jugaron un papel importante al difundir masivamente la información, a diferencia de los contactos, que lo hacían de manera más selectiva, solo proveían información sucinta y poco detallada de la vida cotidiana, únicamente se limitaban a presentar cuestiones estereotipadas, como lo demuestra la siguiente cita: "O sea, yo solamente sabía lo que vi en televisión, en este país había flores para exportación, había piedras verdes, esmeraldas, guerras y ya”.

Otra cuestión también presente es el hecho de que en las migraciones que involucran el núcleo familiar, la toma de decisión y la construcción misma del imaginario es colectiva, y, más aún, es dada en parte en los hogares. La información que proviene de los medios de comunicación es compartida en el hogar, y los imaginarios son construidos con personas significantes, con las cuales se tienen lazos fuertes. Tal fue el caso de Sandra, que viajó con sus hijos a Colombia, y quien ejemplifica muy bien lo anterior: 
Nos dicen que vamos a vivir en Colombia, nosotras no sabíamos que hablar y dijimos ¡a ver! Abrimos la mapa y dijimos, ¿a ver dónde vamos a vivir? [risas] Y vimos como por la selva, después amigos dijeron Colombia, sí, como van a ir a Colombia, eso es un país muy peligroso. Entonces yo y mis hijas pensábamos que íbamos a vivir en medio de la selva en un lugar muy peligroso.

Los medios y la familia constituyeron un actor clave para la construcción de los imaginarios sobre la violencia. La frase de Nicole expone este punto, no solamente se ve cómo los medios influyeron, sino también cómo la construcción del imaginario fue negociada con el grupo familiar: "Poco antes de salir, yo vi un reportaje por televisión donde mataron unos mineros por piedras verdes y mi mamá también lo vio y se asustó mucho y me decía que no viniera, que era muy peligroso y al final yo ya me arrepentí, pero ya tenía todo, no podía decir no".

Como se ha mencionado antes, la información provista por los medios también resultaba fragmentada, por tanto los imaginarios que se construyeron a partir de los mismos eran aquellos más cargados de preconcepto y aquellos que más incertidumbre y miedo podían generar. En contraparte, las personas que se informaban y construían sus imágenes a partir de información provista por colombianos o personas que conocían el país tenían una gama de incertidumbre más baja, tal como lo expresa Ángela: "Expectativas, pocas, conocía ya bastante de Colombia gracias a mi esposo [...] sí, ya tenía nociones del país”, o como lo refiere Nina: "Una 
profesora en Moscú había vivido en Bogotá unos tres años y me contó que no, que era muy bonito, que chévere que nos fuéramos, que conociéramos y me contó un poquito más de la cultura".

Una vez la idea de migrar a Colombia se tornó una posibilidad real para estos migrantes, se dio paso a la construcción de dos ideas de lo que podría ser encontrado en el país receptor, se trata de dos ideas dominantes que comentaremos con detalle de aquí en adelante. En primer lugar, se trata de la idea de Colombia como un país subdesarrollado y en segundo lugar, como un lugar violento. Aunque esta era la idea preponderante de este grupo de migrantes antes de su viaje, resulta necesario aclarar que las personas con vínculos fuertes con colombianos, aunque también migraban pensando en Colombia como un país violento y subdesarrollado, experimentaron menos miedo que aquellos que no tenían dentro de sus redes vínculos estrechos con colombianos o con alguien que viviera en Colombia.

La idea del subdesarrollo era relacionada con la idea de la pobreza, con la incapacidad técnica, la escasez de recursos económicos, la baja escolaridad y la baja renta. El siguiente fragmento ilustra claramente esta conjunción; Serger cuenta cómo le increpaban respecto a su nuevo entorno: "Me decían y aún me dicen si en Bogotá andan en chiva”. Una de las mujeres que migró cuenta el trauma familiar que supuso enfrentarse a la posibilidad de migrar para su familia: "Mis hijos no querían salir, no, no, no ¿a dónde vamos, donde están los micos, la selva? ¡No! [risas] Entiende, sí, porque 
Rusia es un país desarrollado, ¿qué va a hacer por allá?” Su hija decía:

\begin{abstract}
Yo me imaginada que niños van a pedir que regáleme un caramelo, que no sé qué, deme no se qué. Y que de pronto también íbamos a encontrar todas esas palmas, que papá nos iba a llevar al océano tan lindo. Pero no, de todas manera diferentes, yo me imaginaba que iba a ser como Camagüey, que no iba a verse civilización tan avanzada como lo es, o sea yo no tenía esas expectativas.
\end{abstract}

Si bien el subdesarrollo se constituyó como una idea importante a la hora de contemplar Colombia como destino, el principal imaginario estuvo relacionado con la violencia. Hay que recordar que en el tiempo en que se dio esta migración, durante la perestroika y la posperestroika, Colombia estaba atravesando uno de los episodios de violencia más conocidos: la guerra de los carteles del narcotráfico. Durante la década de los ochenta y los noventa, la violencia, por causa del narcotráfico, hizo de Colombia una nación tristemente célebre y estigmatizada en el terreno internacional, representada principalmente por la imagen icónica de Pablo Escobar. Sin embargo, debemos aclarar que en ningún momento las personas mencionaban una violencia en concreto, por el contrario, se trataba de una imagen difusa, quizás debido a la forma fragmentada en que se presentaba la información para ellos.

Llama la atención además que en la construcción de los imaginarios sobre la violencia en Colombia la palabra miedo 
tiene un papel predominante. Lina cuenta: "Mi familia sí tenía miedo, porque Colombia imaginaba terremotos sobre todo, violencia, prostitución”. El miedo fue la respuesta al estímulo que las familias recibieron desde los medios, es lo que experimentaron al conocer la posibilidad de migrar a Colombia y fue la principal razón para desaprobar la movilización. Ángela cuenta lo difícil que fue convencer a su familia de que su viaje a Colombia era seguro; aunque ella expresaba que ya tenía mucho conocimiento del país gracias a su esposo y que no le daba miedo viajar, su familia se oponía a su migración por la idea de que era un país muy peligroso: "Lo más difícil fue convencer a mi familia en Rusia, que Colombia no era ningún infierno, sino un lugar muy agradable, para ellos fue muy difícil, fue un proceso casi de dos años convencerlos, pero ahora ya están tranquilos, saben que estoy bien".

Como veremos, producto de los imaginarios, Colombia no representaba un destino atractivo como sí podían serlo algunas naciones europeas donde las condiciones podrían haber sido potencialmente mejores. Como lo ejemplifica rotundamente la siguiente cita: "Nunca me imaginaba que fuera a vivir en Colombia". Colombia no era percibida como la tierra de oportunidades que se abría para los migrantes, de hecho en muchos casos este lugar solo se contempló al tener propuestas de trabajo concretas.

No obstante, a pesar de que había imaginarios negativos que se oponían a la migración, el hecho de que estos procesos se concretaran pudo haber tenido que ver con que, primero, el estado de las cosas no permitió un cálculo racional, la información era extremadamente fragmentada e imperfecta 
y las condiciones, acuciosas, de manera que tomar una decisión óptima era imposible, es decir, las personas no tenían cómo tomar la mejor opción, sino una decisión medianamente satisfactoria. Como bien lo manifiesta Lee, entre mayores sean los factores de expulsión, menos escogencia del lugar existirá. ${ }^{45}$

A pesar de que Colombia no constituía la mejor opción posible, otro imaginario a favor de la movilización se levantó, al parecer con mayor fuerza que los negativos. Se trató de la idea común a todos de que en su nuevo destino encontrarían oportunidades laborales y algo ligeramente más estable. Este punto lo esclarece con bastante precisión Ángela: “Mi familia tenía miedo porque Colombia imaginaba terremotos, sobre todo violencia, prostitución, para ellos era difícil aceptar mi viaje a este país [...] pero también veían una buena oportunidad para mí porque la caída de la Unión Soviética nos perjudicaba a todos". O como lo expresa Lina, "Él decía (su esposo) que aquí hay opciones, posibilidades y pues entonces la idea era venir aquí y buscar trabajo".

Colombia se presentó entonces como un destino posible gracias a un vínculo dentro de las redes sociales o gracias a ofertas laborales concretas, que terminaron por vincular al migrante en un puesto acorde a su capital cultural. Son estos factores, capital cultural y capital social, los que terminaron por motivar la migración a este país y no el simple hecho de que Colombia se viera como un país de grandes oportunidades.

45 Lee, Everett. "A Theory”. 
Después de dejar claros todos los factores que terminaron por materializar la migración de estos sujetos a Colombia y las imágenes que se traían del país receptor, nos queda por responder la segunda incógnita de esta investigación: ¿Cómo se dio la integración de los migrantes procedentes de Ucrania y Rusia a la ciudad de Bucaramanga una vez se concreta la migración? Para esto nos concentraremos en el siguiente capítulo en exponer los procesos de socialización de estos migrantes y cómo la llegada al nuevo entorno terminó por modificar su identidad. 


\section{Capítulo III. "Yo soy un ruso con sabor colombiano"}

\subsection{Socialización e integración en Bucaramanga}

En el capítulo anterior intentamos responder por qué los sujetos entrevistados en esta investigación migraron, cómo construyeron imaginarios en este proceso, por qué migraron a Colombia y por qué se establecieron específicamente en Bucaramanga, y concluimos que en el acto de migrar se hallan implícitos muchos factores de diversos tipos que influenciaron esta decisión y este proceso. En este capítulo, nos concentraremos en describir y explicar cómo fue su llegada al país, la deconstrucción de sus imaginarios, los conflictos iniciales, su integración dentro de la ciudad, sus procesos de resocialización y las implicaciones de la migración y la integración en sus identidades.

Además, en este capítulo indagaremos por qué estos sujetos, a diferencia de otros de sus paisanos, aún permanecen en la ciudad, a pesar de la reactivación económica y el desarrollo de sus países. Adicionalmente, la exposición de estos procesos nos ayudará a entender la influencia de estos sujetos dentro de la ciudad y sus aportes a la comunidad local. Valga aclarar que todas estas cuestiones no se desligan del proceso expuesto en el capítulo anterior, pues son los lazos construidos en el país de origen, los imaginarios previos a 
la migración, el capital cultural adquirido antes de la movilización y la incidencia de las instituciones, factores que vienen a intervenir en los procesos de socialización de estos migrantes. Pero antes de continuar es necesario detenernos para comentar unos conceptos importantes que nos ayudarán a comprender el proceso de integración de este pequeño grupo de migrantes.

Primero comenzaremos por aclarar qué es entendido como un grupo étnico, pues es un concepto que a pesar de ser ampliamente usado en el estudio de las migraciones humanas, muchas veces no es definido con claridad. Posteriormente, indagaremos cómo en un mismo espacio diferentes grupos étnicos se interrelacionan y se integran.

En la antropología clásica los grupos étnicos eran entendidos como aquellos que se hallaban inscritos a una cultura común, eran comprendidos como colectivos inmutables que permanecían cohesionados al compartir costumbres, mitos y conocimientos comunes. Bajo esta perspectiva, la existencia de una cultura común se convertía en la característica primaria y necesaria para la existencia de un grupo étnico determinado. Los grupos étnicos se definían entonces como grupos con rasgos culturales visibles, no permeados por otras culturas, aislados de otros grupos dispares, donde el contacto con sujetos suscritos a otras culturas significaba una amenaza para el grupo étnico que lo recibía. ${ }^{1}$

1 Barth, Frederik. Los grupos étnicos y sus fronteras. México D. F.: Fondo de Cultura Económica, 1976. Impreso. 
Esta idea de una cultura común, como condición inherente a la existencia de un grupo étnico, es replanteada por Barth. Para este autor, la cultura común no es una característica definitiva de la organización de un grupo étnico, sino el resultado de la creación del mismo. ${ }^{2}$ Según este autor, la identidad étnica no es dada por el simple hecho de nacer en o tener una cultura común, la identidad étnica se construye gracias a la diferenciación cultural y surge en un contexto pluriétnico. La pertenencia a un grupo étnico no es adscriptiva, sino que se define en la interacción con otros grupos, ya que es en esta interacción donde se generan los límites de estos y donde se delimitan las fronteras culturales. Por tanto, el límite étnico es lo que define a un grupo étnico, más que el contenido cultural que un grupo encierra, y este límite solo es construido en dinámicas de inclusión-exclusión que se dan gracias a la interacción con otros grupos.

Para Barth, no es todo el grupo de normas, valores, costumbres, en sí todo lo que encierra una cultura, lo que define a un grupo, sino que cada grupo étnico define los factores socialmente importantes que pueden ser considerados indicadores relevantes para sus miembros y que son aquellos que los identifican y diferencian de los demás, en un proceso de interacción. Por tanto, la pertenencia a un grupo étnico no está limitada a un espacio sociocultural, sino que las pautas de un grupo y sus fronteras étnicas se interiorizan, por lo que Barth manifiesta que los individuos son portadores de cultura. ${ }^{3}$

2 Ibid.

3 Ibid. 
La idea de los individuos como portadores de cultura fue planteada por otros autores como Mead, quien expuso que las creencias, normas y reglas son aprehendidas e interiorizadas por los sujetos mediante un proceso llamado socialización, produciendo lo que Mead metafóricamente denominaba como "llevar a la sociedad dentro", ${ }^{4}$ lo que no es otra cosa que conocer todo ese conjunto de pautas sociales y reproducirlas constantemente en la interacción con otros. ${ }^{5}$ Para nuestro caso, quiere decir que aunque se produzcan desplazamientos espaciales de individuos y grupos, la cultura y sus límites seguirán residiendo en los migrantes. Esta idea es el primer punto que asumiremos para realizar nuestro análisis en las posteriores páginas.

Ahora, en cuanto a la segunda cuestión de cómo los grupos étnicos se relacionan y como terminan por integrarse con otras culturas, producto de la migración, es importante referirnos a Park. Park llevó las ideas del denominado interaccionismo simbólico al ámbito de las relaciones interétnicas en las migraciones, manifestando la importancia de los aspectos simbólicos y subjetivos en las relaciones entre diferentes grupos raciales. ${ }^{6}$ En últimas, Park ubicó el estudio de las migraciones más allá de la etapa del desplazamiento

4 Mead, George. Mind Self and Society from the Standpoint of a Social Behaviorist. Ed. Charles W. Morris. Chicago: University of Chicago, 1934.

5 La interacción es simbólica por el hecho de que es mediada por símbolos, como los gestos o el lenguaje.

6 Park, Robert. "Racial Assimilation in Secondary Groups with Particular Reference to the Negro". American Journal of Sociology 24.2 (1914): 151-170. Impreso. 
dentro del proceso migratorio, dándole importancia a las relaciones que se dan entre grupos étnicos y su proceso de inscripción e integración en la ciudad que los recibe. Park se concentró en estudiar las relaciones raciales, es decir, en el estudio de las relaciones que existen entre pueblos con marcas distintivas de origen, diferencias que penetran en el conocimiento del individuo, determinando la concepción que este tiene de sí mismo y de los demás.

Pero, para continuar examinando el proceso de integración, debemos referirnos al proceso de socialización. La socialización es un proceso comunicativo y simbólico, dado a través de la interacción, en el que el comportamiento y actitudes de una persona o grupo pueden ser comunicados, afectando el comportamiento de otros individuos o grupos. ${ }^{7}$ La socialización es un proceso doble, primero es estructural, en la medida que mediante ella se reproducen las pautas y prácticas de la sociedad en general y de los grupos en particular, donde los individuos son socializados. Al mismo tiempo es individual, pues es un proceso mediante el cual se forma el self. Es un proceso en el cual, mediante diferentes estímulos, se forman las identidades de los individuos.

Por tanto, la socialización se presenta también como una forma de transmitir una cultura y enseñarle a las personas a ocupar un espacio dentro de la sociedad. Para Mead el resultado de la socialización es que el individuo conoce ampliamente las pautas de su sociedad y desarrolla la capacidad

7 Hess, Beth, et al. Sociology. New York: Macmillan Pub Co, 1995. Impreso. 
simbólica para relacionarse con las personas de su misma cultura mediante el lenguaje. ${ }^{8}$ Esto se logra al enseñar a las personas a ocupar su lugar en la sociedad. Es decir, a ocupar uno de los roles que se encuentran disponibles y mostrarles cuáles son las expectativas atadas a esos roles. De tal forma, aunque los individuos tengan deseos y pensamientos originales, están sujetos a las definiciones colectivas que les fueron transmitidas, convirtiéndose la socialización en una forma de control social que actúa sobre el sujeto.

Berger y Luckman añaden que la socialización suele dividirse generalmente en dos tipos, una primaria que sucede en el grupo familiar inmediato, en la cual el individuo en formación aprende su lenguaje, aprende a comportarse y aprende su rol dentro de la estructura familiar y en general en la estructura social..$^{9}$ En esta etapa los padres hacen las veces de agentes de socialización, quienes guían al individuo en su proceso de aprendizaje. No obstante, la socialización es un proceso que no se detiene en la infancia. Aunque debe aclararse que la mayoría de las investigaciones señalan que esta primera socialización es definitiva y ocupa un lugar prominente para las personas, no es la única posible. Para cada nueva situación y cada nuevo contexto donde implícita o explícitamente los individuos deban aprender nuevos roles, comportamientos y sistemas de comunicación simbólica, hay abierta la posibilidad de nuevas socializaciones, comúnmente

8 Mead, George. “Mind”.

9 Berger, Peter y Thomas Luckmann. “La construcción”. 
denominadas socializaciones secundarias, como lo dicen Berger y Luckmann, ${ }^{10}$ o resocializaciones, como lo refiere Hess. ${ }^{11}$

En el caso particular de este estudio, veremos cómo las ideas y figuraciones que traían los migrantes de lo que socialmente se esperaba de ellos cambiaron drásticamente, por virtud de cambiar de cultura y ser expuestos a nuevas normas, a nuevos roles y expectativas. Como consecuencia de este cambio drástico de realidad, los sujetos experimentaron conflictos, ya que el bagaje que traían inicialmente no se ajustaba del todo a los estándares locales, siendo forzados a aprenderlos, en un proceso de resocialización.

\subsection{1. "Uno está como un niño perdido"}

Son múltiples las dificultades que enfrentaron los inmigrantes al llegar a Colombia, el cambio de un universo simbólico a otro, el cual no comprendían ni conocían, resultaba muy problemático, porque significaba hasta cierto punto dejar de lado algunas de sus prácticas y costumbres para asumir otras que podían ser radicalmente diferentes. Aún más, teniendo en cuenta que estos sujetos llegaron de un régimen socialista a un país capitalista, de una federación que fue potencia durante un periodo prolongado a un país con una economía en desarrollo. Estos sujetos llegaron a un territorio con marcadas diferencias sociales, en contraste con un régimen que propendía por la igualdad. Como lo manifiestan estos migrantes, los comportamientos eran totalmente diferentes,

\footnotetext{
10 Ibid.

11 Hess, Beth, et al. “Sociology”.
} 
las costumbres, la forma de relacionarse, además del entorno geográfico totalmente nuevo, con un clima distinto y unas dimensiones diversas. Las tribulaciones, por tanto, se manifestaron desde su llegada en cuestiones tan cotidianas como comer, trasportarse, vestirse, peinarse, hablar, ir de compras, entre otras.

Hay que tener en cuenta que la socialización es un proceso largo y muchas veces traumático que se da durante todo el curso de vida; cada vez que un individuo precise aprender un nuevo rol, una nueva socialización podrá ser suscitada. ${ }^{12}$ Una investigación conducida en 2008, liderada por Stephen White, concluyó que la socialización de los inmigrantes que venían de regiones con sistemas políticos disímiles al de los países receptores era potencialmente más complicada y conflictiva para los individuos, pues los patrones de actitudes y comportamientos de los migrantes eran más difíciles de cambiar, no por el hecho de que los inmigrantes estuviesen necesariamente comprometidos o fuesen activistas en pro de otras ideas políticas, sino porque las creencias, actitudes y comportamientos que habían aprendido desde etapas tempranas de su infancia se sedimentaban fuertemente en ellos. ${ }^{13}$ Este es claramente el caso de los inmigrantes aquí estudiados, quienes venían de un régimen político confrontado con el sistema democrático y capitalista, para quienes

12 Ibid.

13 White, Stephen, et al. "The Political Resocialization of Immigrants: Resistance or Lifelong Learning?”. Political Research Quarterly 61.2 (2008): 268-281. Impreso. 
a pesar de no estar involucrados activamente en política, una porción importante de su vida transcurrió imbuida en el sistema socialista.

Desde el desplazamiento para llegar a Colombia ya se presentaban dificultades, pues no existía una ruta directa de Colombia a Rusia o Ucrania -el flujo hacia y desde estos países no era muy alto. El desplazamiento se tornaba problemático, más que por la larga distancia que tenían que recorrer, por el desconocimiento de los lugares a los que llegaban. Las escalas que tenían que hacer en otros países que no conocían resultaban confusas y la llegada a Colombia aún más dificultosa. De hecho, en muchos de los casos, el trayecto de Bogotá a Bucaramanga tenían que realizarlo en bus, porque el tiquete de avión de Bucaramanga a Bogotá, para la época, representaba un valor muy elevado, teniendo en cuenta que estos sujetos venían con un bajo capital económico, la mejor opción era viajar por tierra. Al llegar a Bogotá y no conocer a nadie, no hablar el idioma y siendo todo extraño y nuevo, ya empezaban a evidenciarse choques con la nueva realidad. Como lo expone Ana, “yo era como un niño perdido”. Las siguientes citas exponen este hecho. Ana cuenta:

Yo lloraba al salir del aeropuerto de Moscú, cuando entendí que nadie me va a entender, me tenían que recoger en el aeropuerto Eldorado y pasar al puente aéreo y cuando llegué veo que nadie me está esperando [...] Empecé a hablar a la señora ahí de policía del aeropuerto en inglés casi llorando, porque era ya oscuro y la noche, todo diferentes 
caras, todo distinto, entonces uno está como un niño perdido, de verdad.

Nicole, por su parte, narra: “En Bogotá tomé bus, no sabía cuánto tiempo duraba el viaje en bus [...] no hablaba idioma español ni una palabra y en el camino el bus se quebró y no entendía qué pasaba, tenía mucho miedo”.

\subsubsection{El papel de los vínculos durante los primeros días}

En el caso de los sujetos que viajaban acompañados por colombianos o que tenían vínculos fuertes esperándolos en Bogotá a su llegada, su desplazamiento fue menos traumático. En esto se podía evidenciar cómo los lazos fuertes en el país receptor y las redes entraron a jugar un papel importante en cuanto al apoyo y la adaptación a la nueva realidad social. Las personas dentro de las redes asumieron el rol de agentes de socialización, guiando a los recién llegados en el proceso de aprendizaje de la nueva cultura. Resulta evidente cómo el vínculo fuerte con un colombiano repercutía en la integración del inmigrante en la red de su vínculo en el país de acogida, lo cual de antemano facilitaba su integración. Es así que Lina fue bien recibida en la casa de sus cuñadas y Olga llegó a la casa de unos amigos de su esposo.

Sin embargo, independientemente de si existía una persona que pudiera catalogarse como vínculo fuerte esperándolos en el país o viajando con ellos, o si el viaje se realizaba solo, el aprendizaje de la nueva cultura fue de hecho traumático. Desde su arribo al país comenzaron a percibir que era una realidad muy diferente. Como bien lo exponen Berger y 
Luckmann, la forma de comportarse en el día a día se da de acuerdo al universo simbólico en el que el sujeto se haya adscrito. ${ }^{14}$ Así, al llegar a un nuevo entorno, hasta las cosas más cotidianas cambian, al estar inscritas en otros universos y símbolos diferentes, por lo cual los conflictos comienzan a presentarse en las actividades consideradas como habituales. Qué comer, a qué hora hacerlo, cómo vestir, cómo peinarse, cómo transportarse son cuestiones que se hayan determinadas por la sociedad y no son inherentes al sujeto. Por tanto, cuestiones que ya están interiorizadas comienzan a parecer extrañas y empiezan a ser distintas y reconocidas como tales.

Las nuevas reglas y las formas de comportarse de las personas en el país que los recibe no son entendidas, lo cual les resulta confuso. Por ejemplo, en algunos casos actos cotidianos como saludar a las personas en Colombia se vuelve algo complicado. Como lo relata Myriam, "aquí todo el mundo saluda, pues yo saludaba a todo la gente, cuando yo camino, no me conocen y me saludan y a mí me parece magnífico, pero al principio es raro, tú no sabes si es que te conocen". Además, los sujetos comienzan a percibir las diferencias en las formas de comportarse y expresarse, cuestiones que creían que estaban bien aquí eran percibidas como incorrectas. Miryam complementa:

Hay cosas también culturales, lo que puedes decir a un ruso no puedes decir a un colombiano en sentido que va a entender de otra manera, sí, porque hay expresiones que tú

14 Berger, Peter y Thomas Luckmann, "La construcción”. 
utilizas en ruso pero están prohibidas acá. Lo que quiero decir es que uno percibe en Rusia que eso está bien, común y corriente, pero aquí uno dice eso y la gente piensa: no, esa señora está como mal ubicada.

Los individuos que antes se inscribían en un sistema de reglas aceptadas como normales dentro de una sociedad, en el nuevo ámbito empiezan a ser vistas como diferentes y extrañas. Como bien lo expone Barth, los valores básicos y las normas de moralidad por las que se juzgan las actuaciones de los sujetos dentro de una sociedad dependen de la categoría étnica implícita en las personas. ${ }^{15}$ Para Barth, el hecho de pertenecer a un grupo étnico determinado abre la posibilidad de juzgar a quienes no se inscriben en estos mismos límites culturales y ser juzgados por aquellos pertenecientes a otros grupos. ${ }^{16}$ En nuestro caso de investigación, el hecho de llegar a un nuevo ambiente, donde las personas poseen una cultura distinta y por tanto sus parámetros morales son diversos al del grupo de inmigrantes, hace que estos no solo se sientan como extraños, sino que sean percibidos como tales. Como lo narra Sandra,

Tú aquí decías cosas y te miraban como raro, aquí hay cosas que pueden ofender, pero que para nosotros no ofenden [...] no sé $[. .$.$] como no saludar tanto o ser muy directo,$ que cuando alguien te molesta lo dices, aquí eso es grosero

15 Barth, Frederik. "Los grupos”.

16 Ibid. 
y pasa que mucha gente no te habla después y tú no entiendes por qué y al rato sabes que se sintió ofendido.

Pero la adscripción a un grupo se refleja no solo en estas categorías morales, sino que, como lo manifiesta Barth, los contenidos culturales que tienen los sujetos se exteriorizan también a través de símbolos manifiestos que los individuos ponen a la vista para enseñar su identidad y pertenencia a un grupo específico. ${ }^{17}$ De esta manera, los límites y la dicotomía entre grupos étnicos se expresan también por medio de códigos visuales, como la forma de vestir, la forma de peinarse, el lenguaje corporal, la forma de vivienda entre otros, donde los individuos ponen en evidencia sus límites y su identidad propia. En concordancia con lo anterior, Tania cuenta:

Nosotras no podíamos aceptar que ponerse medias hasta la rodilla para el colegio, ¡no! Nos poníamos esas medias licradas, ¡sí!, ¡sí! Transparentes o cualquier otro color y hacíamos peinados raros, así como el estilo ruso y todo eso y a los profesores no les gustaba eso y la gente nos miraban como raro. Pero nosotras no queríamos vernos así como los jóvenes de acá con esas medias tan feas hasta la rodilla, nosotras éramos rusas y decíamos a los profesores, pero por qué nos molestan, nosotras tenemos derecho a vestirnos y peinarnos como estamos acostumbradas.

17 Ibid. 
La forma en la que se trata a un sujeto en la sociedad depende de la forma en la que se define este mismo y lo definen los demás, así que los límites étnicos también son establecidos por los otros, gracias a las dinámicas de exclusión. Lina se convierte en un buen ejemplo al respecto, al sentirse extraña en relación con sus cuñadas colombianas, siendo claro cómo no sólo ella se encontraba distinta a los locales, sino también cómo los locales reafirmaban su condición de extraña. Lina narra: "según ellos, yo salía desarreglada a la calle, pero como pues en Rusia no nos importaba tanto eso, pues jumm [...] Entonces uno andaba así; pero ellas no, ellas se arreglaban a veces hasta dos horas, me pareció como demasiado. Ellas, al contrario, les pareció que yo salgo desarreglada, como que por qué yo no me arreglo, les parecía extraño". Nicole, por su lado, expresa cómo era señalada como distinta al llegar y cómo se sentía totalmente extraña:

La gente piensa que si eres blanca entonces eres gringa, entonces uno subía al bus y la gente decía: "gringa mírala, mírala”, y mostraban con manos. Eso realmente lo hacía sentirse como en un zoológico, como de otra especie. Yo ya me sentía que no pertenecía aquí, pero igual era algo que me recordaban todo el tiempo, todo el día, ¡sí!, que era distinta.

La diferencia y el conflicto están latentes en la llegada del migrante en cosas tan básicas como alimentarse, como lo expone Lina: "Pues allá empezó la comida, que tampoco me gustaba mucho, por ejemplo, primero arepas no me 
gustaban, ahora sí me gusta mucho, me parecía que no tenían sabor. Y arroz, que todo el día arroz, calle arroz y como coca cola, pero entonces yo decía, pero ¿por qué arroz?” Por su lado Serger manifiesta: "A veces hasta da un pánico horrible, pues el organismo pide los ingredientes de casa".

Pero el choque no solo se dio en el ámbito social, sino que además el ambiente y el entorno geográfico resultaron complicados. Los inmigrantes, además de que tuvieron que adaptarse al entorno social, también tuvieron que adaptarse a unas condiciones meteorológicas diferentes y a un terreno distinto al que estaban acostumbrados a vivir, lo cual generó problemáticas iniciales importantes que incidieron en el proceso de socialización. Como lo refiere Tania:

Cuando se abrieron las puertas del bus, papá nos recibió en pleno mediodía en el terminal, yo la primera pregunta que le hice a papá fue: ‘ ¿papá, pero nosotros cómo vamos a respirar acá?' Porque es que salir del bus y encontrarse con ese aire tan caliente y tan denso, ¿ ¿sí? Aquí nos vamos es a ahogar, o sea, de verdad eso fue una impresión muy brava y los primeros tres días. O sea, es que el aire tan caliente, ¡dios mío!

Además del clima, el terreno resulta nuevo y cuesta trabajo adaptarse a él, como lo refiere Serger: "En mi tierra todo es plano, en la ciudad plano, plano y ahí sí lo que se acuerda bien, daba pereza salir a caminar porque sube y baja, sube y baja, además se cansa mucho, la humedad”. 
Según Eyles, las áreas geográficas deben ser entendidas en por lo menos dos dimensiones, como el espacio físico donde sus habitantes desarrollan sus vidas con unas normas y funcionamiento establecido, y como un espacio simbólico lleno de íconos y representaciones, donde dichas reglas, costumbres, íconos y significados son aprendidos a través de la socialización y difieren dependiendo de la sociedad de la que se hable. ${ }^{18}$ Es así que la ciudad, su organización y funcionamiento resultaban totalmente extraños para estos sujetos. Al no conocer cómo funcionaba el nuevo escenario social, se evidenciaron complicaciones en cuestiones como el desconocimiento del sistema de transporte dentro de la ciudad o del sistema de coordenadas de las direcciones. Como lo expone Olga, "en Bucaramanga era difícil saber para dónde ibas, ¿qué hay que hacer? No es claro como ir en un metro, tú no sabes esos nombres que llevan los buses”. Pero existían otras cosas dentro de la ciudad que les resultaban aún más problemáticas, como los pocos espacios culturales o su pequeño tamaño para las personas que procedían de ciudades grandes como Moscú. Todas estas cuestiones podían resultar confusas, diferentes y hasta dificultosas. Como lo expone Sandra, "Bucaramanga ¡muy rara vez! Teatros muy poquito, si se presentaba algo, pero eran casos muy así específicos”.

18 Eyles, John y Walter Peace. "Signs and Symbols in Hamilton: An Iconology of Steeltown”. Geografiska Annaler 72.2 (1990): 73-88. Impreso. 


\subsubsection{El lenguaje y la socialización}

Como lo anota Mead, la interacción es simbólica, porque está mediada por el uso de símbolos. El lenguaje es un sistema de símbolos lingüísticos de un nivel sofisticado indispensable para el aprendizaje en la socialización. ${ }^{19}$ Además, Berger y Luckmann argumentan que el lenguaje es el que marca las coordenadas de la vida en sociedad y llena esa vida de objetos significativos..$^{20}$ Por tanto, la comprensión del lenguaje es esencial para cualquier comprensión de la realidad y de la vida cotidiana. En el caso que nos compete es evidente cómo los migrantes sufrieron grandes conflictos internos por no hablar el idioma, siendo el desconocimiento del español el mayor obstáculo que encontraron al llegar. En los casos en que ya tenían conocimientos previos del español, igual se evidenciaban inconvenientes para comunicarse, ya que no entendían en primera instancia lo que les decían por la jerga usada, el acento y la rapidez al hablar. Myriam dice al respecto: "Al comienzo uno está como encerrado un poquito, sí, porque uno no puede relacionarse con las personas por falta de idioma”. Nicole por su parte expresa:

Yo lloraba tanto, porque no tenía con quién hablar, porque no hablaba español, no tenía con quién hablar [...] La gente aquí se acerca fácilmente, sí, lo que para mí era chocante, porque yo no hablaba y la gente se me acercaba y me preguntaba cosas y yo no entendía, hasta que mi amiga me

19 Mead, George. “Mind”.

20 Berger, Peter y Thomas Luckmann, “La construcción”. 
dijo, ya deja de estresarte, aprende a decirles 'qué pena, no entiendo nada', entonces aprendí y solo sabía decir 'qué pena, no entiendo'.

Al ser la interacción con otros individuos la base de la socialización, el idioma además de impedirles la comunicación y poner una barrera con la sociedad receptora, hacía aún más difícil el entendimiento de la nueva sociedad y dificultaba aún más cuestiones de la vida cotidiana, como ir de compras o coger un bus. Serger narra: "Hasta me acuerdo que me tocaba ir al mercado, me preparaba emocionalmente como un par de días antes [risas], como que si me decían algo en el mercado, me asustaba porque no entendía, no sabía qué querían, terminaba escondiéndome de la gente”.

Pero no sólo es el lenguaje verbal el que genera problemas para estos individuos, sino que es relevante referirnos al lenguaje corporal, que es el conjunto de elementos conocidos como kinésica y proxémica, ${ }^{21}$ es decir las formas en que se suceden los movimientos corporales, y la forma en que el cuerpo se orienta en el espacio. Edward Hall entiende estos dos conceptos en el conjunto de relaciones del espacio social y su gran aporte fue añadir que el uso del espacio y del cuerpo son construcciones sociales que tienen significados simbólicos culturales. ${ }^{22}$ Como bien lo acota Hall, en "las

21 El termino proxémica fue acuñado por el antropólogo norteamericano Edward Hall y se refiere al manejo del espacio que realizan las personas al interactuar entre sí, como, por ejemplo, la distancia al hablar.

22 Hall, Edward. The Hidden Dimension. New York: Anchor Books Doubleday, 1990. Impreso. 
diferentes culturas habitan diferentes mundos sensitivos donde la comunicación no es solo lingüística". ${ }^{23}$

El hecho de que la sociedad que los recibe sienta curiosidad y quiera relacionarse con ellos genera mucho más estrés en estos sujetos que no entienden lo que estos dicen, no pueden responder y además no entienden tanta proximidad física; como ellos mismos manifiestan, en sus países las personas son más distantes, físicamente hablando. Como manifiesta Olga,

ahora es bien, pero apenas tú llegas es incómodo, la gente no lo hace porque sea mala, sino por curiosidad, pero se acercan tanto a ti, quieren hablarte y no conservan distancia. La gente aquí llega, se abraza, da beso y ni se conoce, eso es raro para ti, te sentías como agredido al principio, que la gente llegue y te coja el brazo sin conocerte, fue difícil de acostumbrar.

Isabela recalca: "Uy, me acuerdo primera vez que pregunté algo en la calle, el señor me respondió muy amable, sí, pero estaba tan cerca que yo pensé que me quería robar, con el tiempo me di cuenta que ustedes son muy cercanos, hablan como en Rusia novio y novia, cerquita, ya es bonito".

\subsubsection{Del socialismo al capitalismo}

Como bien se ha visto hasta el momento, al enfrentarse los inmigrantes a nuevos universos simbólicos el conflicto es

23 Ibid. 
latente, cuestión transversal a todos los procesos de resocialización en los procesos migratorios. La socialización que se produce cuando se cambia de una cultura a otra puede incluir cambios profundos, porque incumbe un nuevo sistema de símbolos, crea nuevas formas de pensar, refuerza ciertas emociones y moldea la identidad de sus nuevos miembros. Sin embargo, como bien lo señala Tobin, las diferencias pueden ser más visibles entre unas culturas, lo que conlleva a que los procesos de resocialización sean más acentuados. ${ }^{24}$

Tobin argumenta que es necesario explicar que existen algunas diferencias que pueden encontrarse mucho más marcadas entre una cultura y otra, cuestión ejemplificada por el autor en los migrantes chinos que llegan a Estados Unidos. Tobin manifiesta que "algunas culturas, tales como la norteamericana colocan en gran estima el individualismo, otras como la república popular de China, enfatizan la responsabilidad del individuo con el grupo y con la sociedad en general". ${ }^{25}$ Este estudio comparativo realizado entre Estados Unidos, un Estado capitalista, y China, un régimen comunista, demostró que mientras en los Estados Unidos los niños eran educados en las escuelas para desarrollar sus individualidades, en China la socialización en las escuelas era interdictada para corregir cualquier brote de individualismo, promoviendo que todas las actividades se realizaran en grupo, como por ejemplo ir al baño. Esto repercutía en el hecho

24 Tobin, Joseph, et al. Preschool in Three Cultures: Japan, China and the United States. New York: Yale University Press, 1991. 284-297. Impreso.

25 Ibid. 
de que inmigrantes chinos en Estados Unidos experimentaran mayores problemas en sus procesos de socialización en el nuevo país, que inmigrantes de otras regiones.

El caso aquí tratado no es muy distinto al expuesto por Tobin, considerando que estos sujetos estaban acostumbrados no solo a ser provistos por el Estado, sino a vivir de maneras similares, en cuanto a que el gobierno les indicaba dónde vivir, qué consumir, y en general interdictaba varias cuestiones relativas a su vida personal. Estas diferencias tan acentuadas son reconocidas por los mismos actores.El hecho de venir de un régimen socialista, donde el consumo era restringido y donde se propendía por la igualdad de los individuos, cuestión que se reflejaba hasta en la paridad en las viviendas, y llegar a un país capitalista con libertad de consumo y libertad de elección resultó ser algo muy impactante para estos sujetos. Como lo cuenta Nicole: "Sorprende el consumo, digamos, muy americanizada, ¿no? Porque pues allá en ese entonces no había consumo [...] yo digo que en el país no dejan que la gente salga porque eso es algo contagiosísimo, el consumo, ¿sî́? Y bueno, uno después se contagia, también se vuelve consumidor, compulsivo [risas]".

Por su parte Igor plantea: "Aquí, mucha libertad, en vivienda, pero en Rusia apartamenticos siempre pequeñitos, ningún apartamento en Rusia tenía más de un baño [...] diez, cinco personas pueden tener dos metros por baño, entonces incomodidad grande, y apartamenticos pequeños muy pequeños, todos iguales, aquí sorprende casas tan grandes, este apartamento tan grande". 
$\mathrm{Al}$ darse su socialización primaria en un régimen comunista donde todo estaba asegurado para todos y donde no se veían unas clases sociales tan marcadas, ni una marginalidad tan notoria, llegar a un país, además incipiente en su economía, donde los índices de pobreza eran y son altos y donde las diferencias sociales se percibían en todas las ciudades, fue un cambio muy drástico para estos sujetos. Como expresa Tania, "Impresiona mucho desarrollo en la clase media, alta y demasiado subdesarrollo en las clases bajas, entonces, eso lo golpea a uno mucho, porque no se vivió nunca en Rusia. Como te digo, eso fue cuando estaba en el socialismo, pues eso nunca se veía”.

Por su lado, Nina narra: "De pronto lo que uno choca mucho, mucho, pero tremendamente, es la diferencia social tan marcada entre ver tanta pobreza, que nunca la había visto en mi vida. Es un choque muy duro de saber que gente que vive en casa de cartón o en condiciones, como ustedes dicen, infrahumanas".

Sin embargo, a pesar de todas estas problemáticas iniciales, como el alto impacto que causó el cambio de realidad, la dificultad de la comunicación, del entorno geográfico, de la proxémia, entre otros aspectos que hemos mencionado en este capítulo, los individuos comienzan a percibir la necesidad de aprender y entender este nuevo universo simbólico. Como bien lo expone Isabela: “Tú no entiendes nada, tú quieres hablar y no puedes, ves la necesidad de comunicarte, para poder entender, te toca aprender, quieras o no". Esta confusión y conflicto inicial comienzan a menguar en cuanto avanza el proceso de integración y adaptación al nuevo 
entorno social, aunque no podemos afirmar que las situaciones adversas se limitaron al momento de su llegada, están presentes en todas las etapas de la socialización.

\subsection{Aprendiendo a ser colombiano: Integración, socialización y capital cultural}

Dentro de las teorías de la migración, son múltiples los autores que se han referido a la integración y asimilación de los migrantes, desde diversas perspectivas teóricas. En la antropología clásica, se creía que tal integración no existía y que un grupo era absorbido por el otro, borrando toda secuela de su identidad y cultura anterior. La asimilación significaba entonces la anulación de las costumbres que tenía el grupo que se asimilaba, quien se despojaba de sus hábitos para aceptar y asimilar las del grupo dominante. ${ }^{26}$ Bajo esta perspectiva, la idea de dos grupos étnicos conviviendo en el mismo espacio geográfico, conservando características de su cultura, era inimaginada.

Rex, de la escuela británica, fue uno de los primeros en notar que las diferencias entre grupos étnicos existían y se ratificaban dentro de una misma sociedad con un fin: el de dominar al grupo minoritario. ${ }^{27}$ Rex se refería a la teoría determinista para explicar la relación entre grupos étnicos. Para este autor, aceptar las diferencias correspondería a una

26 Barth, Frederik. "Los grupos”.

27 Velasco, Laura y Óscar Contreras. "Raza, clase y etnicidad: un acercamiento a la sociología de John Rex”. Revista Mexicana de Sociología 68.1 (2006): 81-102. Impreso. 
situación justificada por los grupos dominantes en función de algún tipo de sometimiento. Según Rex, el término de raza era usado en la sociedad para explotar y someter al inmigrante, era un discurso manejado por los dominantes, justificado generalmente en teorías biológicas o genéticas. Para este autor, la coexistencia de dos grupos étnicos no concluía entonces en una integración exitosa, pues el grupo minoritario nunca iría a alcanzar representación ni lograría ocupar un estatus privilegiado en el espacio social. Por el contrario, para Rex las relaciones étnicas se caracterizaban primero por un conflicto acentuado entre el grupo dominante y el grupo minoritario, que concluía siempre en la explotación, la discriminación, la opresión y la falta de movilidad laboral del grupo más pequeño. ${ }^{28}$

Esta perspectiva de la dominación del grupo mayoritario es la base de muchas teorías de la integración en la migración, de las cuales Castells, sociólogo español neomarxista, es un gran expositor. Para Castells, la integración del migrante se da en la clase social más baja de la pirámide social: la clase proletaria. ${ }^{29}$ Este autor expone que los migrantes laborales se insertan en una clase proletaria y que su inserción no se da en la parte más alta de la misma, sino que esta clase proletaria se encuentra dividida en tres, ocupando los nativos la parte alta de la pirámide proletaria, abajo los migrantes legales y, por último, los ilegales. Los migrantes, por tanto,

28 Ibid.

29 Castells, Manuel. The Rise of the network society: the information age, economy, society and culture. New York: Willey-Blackwell, 2009. Impreso. 
devengan salarios menores y obtienen los peores empleos, estando siempre por debajo de los nativos y dominados por el grupo receptor, sin existir una integración real del migrante a la sociedad receptora. ${ }^{30}$

La escuela estadounidense, particularmente la Escuela de Chicago, se destacó por el estudio de las relaciones raciales dentro de la ciudad. Sin duda, los trabajos de Park y Burgess fueron unos de los más representativos en el estudio de la integración de los migrantes y de las relaciones entre grupos étnicos. Estos autores argumentaban que los individuos, al llegar al país receptor, pasaban por distintas etapas en la integración, a las cuales denominaron el ciclo de relaciones raciales, conformadas por la competencia, el conflicto, la acomodación y la asimilación. ${ }^{31}$ La competencia a la que Park hacía referencia se daba entre las personas que migraban y las que previamente ocupaban el país, en la pugna por ocupar un lugar dentro de la sociedad y en el mercado laboral. Por su parte, el conflicto al que este mismo autor se refería acaecía cuando la pugna entre los grupos raciales se tornaba evidente, en la que los inmigrantes se organizaban en busca de obtener aceptación y reconocimiento social. La acomodación surgía cuando los conflictos habían sido trascendidos y los inmigrantes lograban acomodarse al lugar de destino, ganando cierto reconocimiento, provocándose

30 Ibíd.

31 Burgess, Ernest y Robert Park. "Cultural Conflict and the Marginal Man". Introduction to the Science of Sociology. Chicago: The University of Chicago Press, 1921. Impreso. 
ajustes entre los grupos raciales y los individuos. Por último, la asimilación aparecía cuando los grupos se habían ajustado mutuamente y al nivel personal se comenzaban a crear ideas, expectativas y creencias comunes, desarrollando una cultura común y compartida. ${ }^{32}$

Sin embargo, todas estas teorías que hablan de las relaciones entre grupos étnicos y la inserción de los migrantes en la sociedad se enmarcan en principios económicos y políticos, limitando su rango interpretativo. Desde la teoría de Park hasta la de Castells, se puede ver que el conflicto emerge en la esfera laboral, en la cual los inmigrantes son marginados. Pero en nuestro caso particular esto no sucede así, debido a que los migrantes a los que nos referimos aquí no llegan a ocupar un lugar marginal dentro de la sociedad que los recibe. Del mismo modo, su inserción en el mercado laboral tampoco es conflictiva, en relación a no conseguir oportunidades laborales o estar subvalorados. Por el contrario, estos sujetos, al igual que en el caso de otros migrantes en la historia de Colombia, llegaron a alcanzar estatus altos y lograron posicionarse en puestos laborales acordes con su capital cultural. La integración a la vida laboral no fue conflictiva y, tal como hemos visto, muchos ya venían con propuestas laborales claras y los que no las tenían lograban insertarse rápidamente en el mercado laboral en posiciones adecuadas a su formación.

Bajo estas perspectivas teóricas generalmente se habla de la subvaloración de los inmigrantes en un ambiente laboral,

32 Ibid. 
donde así tengan el mismo o mayor capital cultural que los nativos, ocupan un lugar más bajo en la pirámide laboral. Pero en este caso, tal efecto no se produce, por el contrario, sucede lo opuesto. Primero hay que hacer énfasis en el punto que habíamos tratado en el capítulo anterior, el alto capital cultural que detentaban estos sujetos, que era considerablemente mayor en relación con el de las personas del lugar de destino, lo que facilitaba su incursión en el mundo laboral. Segundo, como lo refiere Nicole, en muchos casos era preferido el extranjero, aunque los inmigrantes tuvieran el mismo capital cultural que una persona de la sociedad huésped, gracias a los imaginarios creados sobre ellos por la sociedad receptora. Nicole, por ejemplo, plantea: "Yo diría que prefieren al extranjero y no siempre es justo, aquí mucha gente piensa que por ser extranjero, por el solo hecho de que tú eres extranjero eres más listo, que eres mucho mejor, que sí les va a cumplir los horarios y eso no siempre es cierto".

Como bien lo define Barth, el puesto que ocupa un grupo dentro de una sociedad depende en gran medida de cómo este es definido por los otros. ${ }^{33} \mathrm{El}$ comportamiento y el espacio que ocupa un individuo se debe no solo a los imaginarios que este ha construido, sino a los imaginarios que los otros construyen de él.

Su capital cultural, además de permitirles ingresar al mercado laboral de manera rápida, también les permitió tener un estatus alto dentro de la sociedad, lo que terminó por beneficiar su integración. Con lo anterior, no se quiere decir que

33 Barth, Frederik. "Los grupos". 
hayan sido aceptados como iguales, pero no existió rechazo manifiesto hacia esta población. De hecho, las relaciones con colombianos se tornaron más fuertes y frecuentes una vez aprendieron el idioma.

Por tanto, la definición de Bourdieu podría darnos luces sobre la integración de nuestro grupo de estudio, ya que para este autor la integración y la distancia entre los agentes dependen de los capitales que estos detenten. Además, la visión que estos tienen de un punto determinado de la realidad depende de la posición que ocupen en el espacio social. ${ }^{34}$ Así, los inmigrantes aquí referidos, al tener un alto capital cultural, lograron insertarse fácilmente en la vida laboral. Sin embargo, el simple hecho de tener un capital cultural no garantiza una integración exitosa. En Estados Unidos, por ejemplo, los inmigrantes soviéticos no se insertaron tan fácilmente en el mundo laboral, aunque también poseían un alto capital cultural. Entre otros obstáculos, el gobierno les decía que sus conocimientos no eran homologables, degradando su estatus, por lo que debían iniciar de nuevo sus estudios.

El hecho de tener un alto capital cultural no explica en sí la rápida integración al mundo laboral, hay que tener en cuenta, además, como lo refiere Bourdieu, la distancia entre los agentes y el lugar que ocupan estos sujetos en el espacio social. ${ }^{35}$ Hay que considerar que estos sujetos que llegaron a Bucaramanga tenían un capital cultural por encima del

34 Bourdieu, Pierre. "El espacio social y la génesis de las 'clases'”. Estudios sobre las Culturas Contemporáneas III.7 (1989): 281-309. Impreso.

35 Ibid. 
común de la comunidad local. Es un caso muy diferente al de los inmigrantes soviéticos en Estados Unidos, donde los individuos detentaban capitales equiparables, por lo que los inmigrantes sí entraban en la competencia referida por Park por buscar un lugar en el espacio social, compitiendo con los nativos. Pero, además, esta situación debe leerse a partir de los imaginarios que la sociedad receptora ha creado alrededor del migrante. En el caso aquí estudiado, como lo refiere Nicole y como se podía apreciar en el momento de la observación, estos sujetos eran concebidos por la sociedad local como inteligentes, disciplinados y con una alta capacidad de trabajo. Por el contrario, la comunidad estadounidense no veía con buenos ojos el mundo soviético, en parte por las secuelas de la Guerra Fría, lo que generó el rechazo a estos inmigrantes.

Sin embargo, aunque no creemos que estos sujetos pasaron por una competencia y que su conflicto no se manifestó en la organización política de este grupo, sí creemos, como Park, que la integración se dio en las relaciones entre grupos étnicos y entre los sujetos. Además acreditamos que los inmigrantes, después de pasar por algunas etapas, terminan por adaptarse y por asimilar la nueva sociedad, gracias a un proceso de socialización donde el sujeto aprende y entiende las normas del nuevo entorno social, que a continuación analizaremos con detalle.

\subsection{Paisanos y nativos como agentes de socialización}

En el proceso de integración y adaptación a la sociedad existe una serie de agentes e instituciones que intervienen 
en la instrucción de comportamientos, reglas y actitudes que guían al sujeto e influencian la interiorización de las pautas; estos son corrientemente denominados agentes de socialización. ${ }^{36}$ Como enunciamos, durante la primera socialización los padres y otros familiares pueden ser importantes, pero, posteriormente, los medios de comunicación y otras personas pueden llegar a serlo. Particularmente, para este caso, las personas dentro de la red pueden ser consideradas como agentes de socialización: los compañeros de trabajo, los compañeros de estudios o los compañeros sentimentales. Estos procesos de acomodación y asimilación del entorno se dan de forma diferenciada en los sujetos, dependiendo de sus redes sociales, como también del momento del ciclo vital en el que se encuentren, cuestión en la que profundizaremos posteriormente.

A diferencia del momento previo a la migración, cuando los lazos débiles eran de gran importancia a la hora de determinar la migración, ayudando al migrante a insertarse en la vida laboral y abriéndole nuevos horizontes y posibilidades que en su red densa no existían, en este caso son los vínculos fuertes los que mayor apoyo brindan al sujeto a la hora de la socialización y facilitan su entendimiento y asimilación del nuevo espacio social. Algunos lazos fuertes resultan ser más útiles que otros a la hora de la integración, en los casos estudiados los lazos con colombianos fueron los que más facilitaron el proceso de socialización. Aunque no

36 Hess, Beth, et al. Sociology. New York: MacMillan Pub Co., 1995. Impreso. 
en la misma medida que con los lazos fuertes, las relaciones con lazos débiles, como alumnos o nuevos compañeros de trabajo, también ayudaron en sus procesos de integración, cumpliendo un papel relevante en el aprendizaje y entendimiento de la nueva cultura a la cual estos migrantes se vieron enfrentados.

Aunque lo hemos dado por sentado, debemos hacer explícita una cuestión de suma importancia: el hecho de que la socialización y el proceso de integración de los migrantes se dan en un segmento bastante reducido de la sociedad receptora. Los rusos y ucranianos aquí estudiados entraron en contacto con personas en redes bastante especializadas dentro de las instituciones, redes compuestas por personas que tenían cierto estatus con características peculiares. Las redes donde estos migrantes resocializaron pertenecían a un nivel socioeconómico medio o alto dentro de la ciudad y detentaban un capital cultural alto. Este hecho determinó que las personas aprendieran las costumbres propias de ese grupo, sus modos de dicción y sus modos de comportarse en la ciudad, así como los sitios en los que se instruirían y laborarían.

En el caso aquí estudiado no existían migraciones anteriores ni una red consolidada de estos inmigrantes, ni existían redes de apoyo tan marcadas como las que existen en migraciones de mayor duración, como en el caso de los colombianos en los Estados Unidos. Por tanto, en muchos casos el inmigrante llegaba al país sin conocer a nadie directamente, siendo las instituciones, como las universidades a las que ingresaban, las que les proporcionaban ayuda en primera instancia. Como les sucedió a David, Igor y Nicole, 
estas instituciones enviaban personas que sabían el idioma para recogerlos en el aeropuerto y ayudarles los primeros días mientras conseguían dónde instalarse, sin embargo, este apoyo no iba más allá. Cómo narra Igor:

Me tenía que encontrar un profesor de la universidad X que mandaron a ayudarme en el aeropuerto y no llegó, entonces, ¿qué hacer? Yo tenía que ir a su apartamento porque él sabía ruso, porque él estudió en nuestra universidad pregrado y terminó allá maestría y doctorado [...] él dijo que llegó tarde. Salí y un taxista yo entregué el papelito con la dirección, llegamos ahí. En su apartamento sólo duré un día, no sé por qué me sentía como incómodo, uno, dos días y ya. Después llegué aquí, arrendé apartamento y comencé solo.

Sin embargo, en el caso de las personas que llegaron casadas con colombianos o que conocían un coterráneo en el país, estos agentes les ayudaron en su instalación los primeros días en el país y se convirtieron en parte fundamental en todo su proceso de integración y adaptación al nuevo entorno. Particularmente para las personas que llegaron casadas con colombianos, su esposo, la familia y amigos de este se convirtieron en sus primeros agentes de socialización. Como Olga expone: "Familia de Juan nos recibió muy bien, desde principio grande amistad con la hermana muy parecidas, gran apoyo de la familia”. Por su lado, los agentes de socialización de las personas que llegaron sin un vínculo fuerte con un colombiano fueron compañeros de trabajo o coterráneos 
que hallaron en el país. En primera instancia estos agentes de socialización eran personas que hablaban su idioma. Como bien lo refiere Mead, es por medio del lenguaje que se da el aprendizaje simbólico de la cultura y el que permite la interacción entre los sujetos. ${ }^{37}$

No obstante, como bien lo refieren los sujetos aquí entrevistados, las personas que venían casadas o que tenían vínculos fuertes con colombianos experimentaron una integración mucho más rápida gracias a la socialización con ellos, aprendiendo de una manera más acelerada tanto el idioma como las costumbres. Como lo refieren Mead, ${ }^{38}$ Berger y Luckmann, ${ }^{39}$ los agentes dentro de una sociedad son reproductores de esta misma. Así, estos colombianos con los que se tenía un vínculo fuerte podían comunicar de una forma mucho más fácil los conocimientos y reglas del nuevo entorno social al que se enfrentaban los inmigrantes, al tener interiorizada la sociedad colombiana. De igual manera, al haber vivido en los países de procedencia de sus amigos o compañeros sentimentales, conocían el idioma y su cultura.

Sucedía diferente con las personas que llegaban con la ayuda de un coterráneo, pues aunque este era de vital importancia y apoyo al recién llegado, también se hallaba en su proceso de adaptación al nuevo entorno -la diferencia de

37 Mead, George. Mind Self and Society from the Standpoint of a Social Behaviorist. Charles W. Morris (ed.). Chicago: University of Chicago, 1934. Impreso

38 Ibíd.

39 Berger, Peter y Luckman, Thomas. La construcción social de la realidad. Buenos Aires: Amorrortu, 1986. Impreso. 
tiempo entre una migración y otra era máximo de dos años. Además, no se tenía la misma frecuencia de contactos que tenían los sujetos que poseían relaciones más cercanas con colombianos. En el caso de aquellos cuyos agentes de socialización eran sus coterráneos, solo se brindaba el apoyo en ciertos espacios, ya en otros el sujeto se hallaba solo enfrentando la nueva realidad. Como bien lo manifiesta Myriam:

Yo duré como tres años en acostumbrarme porque mira, yo te puede decir, si tú llegas con un colombiano o colombiana, tú te acostumbras mejor porque ya la pareja tuya te explica, como que te hace introducciones de todo. Pero si uno viene con su hijo en la casa y nadie lo guía, sí, ehhh, y si no hay amigos o amigas que te puedan decir, entonces eso lleva más tiempo, ¿̇me entiendes?

En el caso de aquellos que no tenían vínculos fuertes con colombianos, el hecho de que estuvieran vinculados a una institución ayudaba a sus procesos de aprendizaje y socialización, aunque estos fueran más traumáticos. Se puede ver cómo en estos casos los espacios en los que se comienza a dar la socialización es dentro de las instituciones. Así, aquellos que llegaron de una vez a laborar o, en el caso de sus hijos, a estudiar, lograron socializarse gracias a las relaciones con compañeros, alumnos y colegas en sus lugares de estudio o trabajo. Cuenta: "Los compañeros de trabajo son amables y los alumnos muy curiosos, pero también disponibles a ayudar, me corregían el español y muy interesados en los temas". 
Por su lado Ana narra cómo sus alumnos la ayudaron en este proceso de socialización. "Alumnos muy amables conmigo, sí, y la facilidad de música es que uno puede tocar, mostrar y ya uno entiende, sí [...] pero sí me recibieron muy bien y me ayudaron mucho".

En esta línea, Sandra relata: "Cuando yo decía la palabra muy mal, los alumnos se reían, pero corrigen, más importante no tener tímido, no ser bravo ni nada, porque tú estás aprendiendo".

En los lugares de trabajo, dentro de las instituciones universitarias, apreciamos el hecho de que los paisanos entran a desempeñar un rol como agentes de socialización importante, ellos indican a las personas algunas de las nuevas normas sociales basados en su propia experiencia. Esta labor de apoyo es significativa, porque evita a los recién llegados algunas contrariedades. Myriam explica que a ella le informaron, por ejemplo, "lo que puedes decir a un ruso, no puedes decir a un colombiano [...] mis amigos me decían, no, no digas eso, dilo de otra manera, dile eso, ¡eso no! Guarda eso".

En este punto resulta necesario referirnos a la diferencia en el aprendizaje de la cultura dependiendo de ciclo vital de estas personas. Para el caso de los inmigrantes de mayor edad, sus hijos hicieron las veces de agentes de socialización. Varios han descrito que sus hijos se adaptaron más rápido que ellos al nuevo entorno, que aprendieron el idioma en menos tiempo, asimilando los modos y costumbres velozmente. Igor cuenta: "Yo enseñaba español a mis hijos, Demetrio, sentado pequeño escuchando como enseñaba español con mi mal acento. Enseñaba y él callado, nunca decía nada, no 
hablaba una palabra en la casa de español, yo pensaba, 'es pequeño, va a demorar'. Pasó un mes y en mi clase dijo: ‘aaishhhh, aquí nadie sabe hablar español!' Y lo dijo en español perfecto, sin ningún acento”.

Myriam también llegó con su hijo de menos de 9 años. Cuenta: "Mi hijo aprendió en dos meses español, en dos meses ya hablaba bien, pero yo me demoré como medio año para ya expresarse. Él habla sin acento, ya mejor dicho [risas] habla mejor español que ruso". Además, al integrarse más rápido a la sociedad, los hijos funcionan como mediadores entre el mundo soviético y el colombiano, al explicar a sus padres los modos y costumbres que han aprendido en sus colegios, en la socialización con más niños. En este sentido, el rol de los hijos es ayudar a que los padres no sean sometidos a situaciones tan frustrantes, además de ayudarlos a insertarse en el mercado laboral, como lo narra Sandra:

Después de separarme, yo necesitaba trabajar, hija estudiaba en escuela $X$, entonces necesitaba aprender español para conseguir el trabajo. Yo soy profesional y entonces yo fui con mi hija que estudiaba en el colegio, dije, 'hija vamos conmigo y explique para profesor, yo no quiero el trabajo, que me permitan solamente participar en la clase de X', yo miraba para aprender cómo aquí daban la clase, cómo eran las clases de educación física, para aprender terminología, ¿sí? Y entonces me fui para allá, ahí la hija explicó: mi mamá quiere aprender, no pretende el trabajo, pero solamente para aprender idioma, ¿ustedes permiten 
por favor para participar de la clase? Y así dure un tiempo y después me dieron trabajo ahí.

Los hijos son entonces quienes enseñan a los padres cuestiones de la nueva cultura. Aunque al principio la integración al país fue complicada para aquellos que llegaron en edades tempranas, como los hijos de Serger, Sandra, Myriam y Ana -con un rango de edades entre los cinco y los nueve años-, este conflicto se superó de forma más rápida y la integración se dio de manera más corta.

\subsection{1. ¿Existe una comunidad soviética?}

Como vimos en el apartado anterior, es claro que en los procesos de aprendizaje del nuevo entorno la ayuda de sus coterráneos fue fundamental en los procesos de aprendizaje de algunos inmigrantes. Aunque en varios casos se presentaron labores de apoyo y conducción a los sujeto por una ruta que generara menores traumatismos, esto no significa que existiera una comunidad.

La comunidad en este caso particular no existe como tal, en el sentido de que no existen relaciones prolongadas ni muy cercanas entre todos los inmigrantes soviéticos. Muchas veces ni siquiera se interrelacionan entre sí, prevaleciendo el anonimato. Se trata, más bien, de casos en los que las personas, al ser insertas en una institución, entran en contacto con personas de su misma nacionalidad, creando amistades o reforzando la amistad que traían de sus países. Estas, sin embargo, se constituyen en redes fragmentadas con sus paisanos en vez de una gran red que los aglomere a todos. Como 
lo cuenta Igor: "No, pues, con mi colega ruso de la facultad nos reunimos de vez en cuando, no con tanta frecuencia". $\mathrm{O}$ como es el caso de los migrantes ucranianos en la universidad X, quienes están todo el día en el trabajo, sin que esto signifique que sus encuentros afuera sean frecuentes.

Por supuesto, hay casos que indican lo contrario, pero son menos frecuentes, y aunque los vínculos sean muy fuertes, las redes son muy pequeñas. Sin embargo, como lo explana Lina, el contacto con gente del país no siempre se da: "Yo casi no tenía amigos rusos. O sea, sí tenía conocidos en la universidad donde trabajaba, para mí entre rusos y ucranianos entonces mejor era, 'hola, ¿cómo estás?', 'Bien', ‘¿Tu hijo?’, 'Bien, ¿y tú?', 'Bien'. Listo, y ya”.

Aunque las causas de la ausencia de una comunidad no son del todo claras, un indicio de esto puede ser que muchas de las relaciones entre los individuos se deterioran después de un periodo de tiempo de contacto, al formar redes muy densas pero muy pequeñas, como lo cuenta Lina:

Había un par de rusas que me decían: ¡yo no! Con rusos no tengo amigos, yo no los entendía, ¿̇pero por qué? [...] yo quería tener muchos amigos rusos y los empecé a tener. Pero después al final yo entendí que, que eso es mejor no tener, porque como círculo era muy pequeña, entonces, bueno, empieza a decir persona una cosa, él la cambia, lo dice a otra, como un teléfono dañado [...] muy amigos pasan dos, tres años y ya no eran amigos. 
Otros coinciden con el punto de Lina, como lo señalan las siguientes citas: Ángela dice, “Absolutamente ninguna, no tengo ningún tipo de relación con ellos, como te conté, no hago parte del grupo influyente de rusos en la ciudad"; Serger complementa, "Pues debería ser como, ¿no? Ahh sí, son pocos, entonces tiene que estar todos unidos, yo sé que aquí hay, que hay muchos más, pero no los conozco"; Olga por su lado expone: "No tengo mucho contacto, pocos amigos rusos, sé quiénes son, tengo respeto como profesionales, y disponible de prestar la ayuda necesaria, pero amistad no mucho, desde principio poco contacto con ellos, solo con Isabela y otra amiga [...] ellas tampoco tiene mucho contactos con ellos, es complicado relación con rusos”.

Aunque de facto no exista una comunidad, esto no quiere decir que no se hayan realizado esfuerzos tendientes a la construcción de la misma. Varios de los participantes en este estudio relataron el hecho de que hace algunos años se promovió un evento auspiciado en la Casa de la Cultura de Bucaramanga, planeado como una velada para integrar a las personas provenientes de la región soviética. Igor comenta cómo él participó como organizador de aquella velada:

Yo una vez organicé aquí un día de rusos aquí en la casa de la cultura y fue gobernador y todo, un día de Rusia aquí en casa de la cultura, allá vinieron egresados de universidades, llegaron como 200 personas, rusos, ucranianos y armenios, yo hice comida con vodka con todo, mucha gente. Hicieron un concierto de música rusa, comida rusa, había una exposición de pintoras rusas. Fue como hace 4, 5 años [...] 
Yo tenía una lista, pero ahora ya no está, ya no recuerdo, yo les mandé una lista a embajada, pero la embajada es un desorden. Después yo olvidé esto porque mucho trabajo, pero sí se hizo un trabajo de lista y teléfonos, solo que yo perdí y embajada muy desordenada también, como tratando de encontrar a todos los que están, después es difícil.

El evento se concretó y fue exitoso, como lo narra Myriam:

Era en casa de cultura, ¿sí? Era bien agradable, cantamos, invitamos también la gente de acá y cantamos canciones rusas, porque yo invité a los cantantes de acá, ellos aprendieron a cantar en ruso [risas], era bien agradable y para esa época ya había como 100 personas, eso es lo que nos dijeron, pero creo que ya debe existir el doble o más.

La iniciativa se detuvo en ese momento y la construcción de comunidad quedó truncada. Igor comenta, "cada vez tratamos de reunirnos pero al fin y al cabo no se puede, la vida nos separa". Esto dio como resultado que las redes continuasen fragmentadas. Nina denota este hecho señalando que son redes diferentes, "Papá y mamá sí tienen amigos rusos, papá tiene los suyos de su universidad, mamá tiene amigas de la suya”.

Otro factor que podría darnos indicios sobre por qué no existe una comunidad establecida, ni un lugar de encuentro concreto para esta comunidad, como una casa de la cultura, a pesar de ser un número de migrantes significativos, puede 
ser el hecho ya mencionado de la clausura de la Casa de la Amistad con los Países Socialistas.

Esta institución, según los relatos, fue clausurada por haber sido supuestamente, centro de reuniones de izquierda, además de ser catalogada por algunos como un lugar donde se esparcían las ideas comunistas y socialistas y donde se encontraban distintos movimientos de izquierda. ${ }^{40}$ De allí un estigma que se generó alrededor de este lugar y que, aunque no es mencionado por los entrevistados, podría tener algo que ver con el hecho de que no se pretenda organizar de nuevo un centro de reunión de ciudadanos que pertenecieron a la URss. Esta hipótesis podría ser explorada en estudios ulteriores.

Cabe anotar que, aunque estos sujetos han logrado integrarse satisfactoriamente a la ciudad, puede ser que aún recaiga sobre ellos algunos estigmas asociados a los imaginarios que se crearon alrededor de la URss, más que a las ideas políticas reales de los inmigrantes.

Aunque los relatos son aislados y el total de los entrevistados manifestó no sentirse estigmatizado ni asociado a ideales políticos, estos hechos, aunque poco comunes, pueden tener algo que ver con la inexistencia de una comunidad. Es una hipótesis que debe ser explorada más a fondo en otros estudios.

40 Estos comentarios alrededor de la casa de la cultura podrían ser mitos urbanos más que hechos reales, mitos basados en el estigma que en los años ochenta tenía la URss. Esta imagen negativa se debía en parte a la Guerra Fría, teniendo en cuenta que la mayoría de información que llegaba a Colombia era por parte de USA. Véase elfrente.com.co, “Cano". 
No obstante, la idea de la presencia de otros soviéticos es clara. Aunque no existe una comunidad tangible, entendiendo esta como vínculos prolongados entre los inmigrantes, estos son conscientes de la presencia de otros inmigrantes soviéticos en la ciudad y es común que en sus relatos se refieran en plural a un grupo con el cual se identifican: "Nosotros, los rusos que estamos aquí”. Como lo ejemplifica Nina,

hay bastante gente de música, en la Universidad X, de química en la universidad $\mathrm{X}$ hay bastantes, de física, está papá [...] hay unos pintores, hay otros que trabajan con la empresa pública $\mathrm{X}$, ¡Sí! Ya todo son mayorcitos, somos muchos los rusos que estamos aquí, pero hablarme con ellos, no, sólo con mis hermanos, papás y Nicole, mi amiga ucraniana.

Para concluir este punto podemos plantear que la ausencia de una comunidad visible de migrantes soviéticos también puede explicarse si tenemos en cuenta que antes de la llegada de estos sujetos no existían muchos inmigrantes soviéticos en la región y, por tanto, no existía una comunidad establecida que fuera base para los recién llegados, como sucede con otros flujos migratorios donde ya existe consolidada una comunidad por un flujo continuo de migrantes de la misma nacionalidad a determinado país, como el caso de los colombianos en Estados Unidos. Además, debemos considerar que estos inmigrantes no llegaron producto de una misma red social, su migración se debió a vínculos y lazos específicos, quienes los ayudaron en sus procesos de 
integración y en el establecimiento de sus redes. Además, hay que considerar que esta migración no se inscribe bajo la teoría de la causación acumulativa, muy por el contrario, esta es una migración que no ha repercutido en la llegada de más migrantes de estas nacionalidades a la región. Cabe recordar que esta migración se caracterizó por el arribo de estos migrantes por motivos coyunturales, como la crisis social, económica y política que vivían estos países en el momento de su migración, cuestión que abordamos en la segunda mitad del primer capítulo. Una vez la economía de estos países se recuperó y por tanto las crisis sociales menguaron, la migración a Colombia desde estos países cesó.

Además, la ausencia de una comunidad puede deberse a la integración satisfactoria que en el momento presentan estos migrantes, quienes consiguieron adaptarse de manera exitosa a la sociedad receptora. Es de considerar el hecho de que estos sujetos no llegaron en una situación de rivalidad con los nativos, ni de segregación y exclusión patente, por lo que la integración se hizo más sencilla. Esto también puede explicar por qué no resultaba tan necesaria para estos sujetos la organización de un grupo con el fin de reivindicación o de un reconocimiento social o político, como sucede en otros casos.

\subsubsection{El camino a la asimilación}

Hasta este punto hemos señalado cómo comienza a darse el proceso de aprendizaje del nuevo entorno y la resocialización de los individuos. Sin embargo, hay que aclarar que este proceso no es lineal ni inmediato y que las dificultades 
están presentes en todas las etapas de la resocialización, lo que se refleja en que después de un tiempo de haber llegado a Colombia, en ocasiones siguen pensando en volver a sus países. El hecho de que en principio los individuos aprendan normas y comportamientos de la nueva cultura no significa que hayan terminado por integrarse. Myriam narra: "Claro, claro, uno piensa en regresar porque a quién le van a gustar los obstáculos o algo que te estrese, que te haga sentir mal, ¿sí? No es que todo está mal, sino que tú te sientes alguien extraño porque eso lleva tiempo, no solo idioma, costumbres, ¿̇sí?” Tania expresa además la contingencia de la crisis:

Es que acostumbrarse es muy difícil, toda esa frustración que tienes. Hasta un día, íbamos a cometer una locura: nos paramos las tres en la terraza y nos cogimos de la mano e íbamos a saltar del quinto piso con mis hermanas y yo creo que un ángel fue que nos paró y nos dijo que no lo hagan. Esperen un momento más, que no sé qué, que las cosas se van a dar. Pero duro, duro, ¡no! Fue una crisis, familiar, personal, ¡no! Fue muy duro, al final lo logramos. Cambiar de identidad, todo eso ocasionó como una crisis en nosotras, y nosotras como que perdimos como la ruta. Ahora estamos felices, pero todo este proceso de adaptarse fue muy duro.

El proceso resultaba tan difícil para algunos que no lograban adaptarse a pesar de llevar ya algunos años viviendo en el país, de haber aprendido el idioma y algunas costumbres que terminaron volviendo a sus países, sin importar que la 
crisis económica y política en estos seguía latente. Como lo relata Sandra, "aquí hay parejas que tienen esposo colombiano o vienen solas, viven muchos años, y después de mucho tiempo ella se va otra vez para Rusia porque no soy capaz de adaptar a esta cultura, no son capaz”.

En suma, la resocialización es un proceso no lineal, la mayoría de las veces problemático. La integración a la nueva cultura no se trata simplemente de aprender el idioma, las costumbres y aprender a comportarse en el nuevo entorno, además hay que aceptar todos estos elementos, asimilarlos, es decir, interiorizarlos. Esta problemática se resume en la afirmación de Isabela: “yo aprendí el idioma, pero después hay que aprender la mentalidad de la gente, aceptarla, eso es lo más difícil”. Sandra, complementa:

Es que necesitas mucho tiempo para aprender y necesitas aceptar esa cultura, aprendes idioma, pero después tú debes aceptar la forma en la que piensan aquí, sí, porque las rusas son más directos, más agresivos y yo por ejemplo, si yo pienso yo te digo en la frente guste o no guste, pero aquí no, aquí no puede, aquí tú piensas, pero no debe decir solo lo que necesita no más, pero tú quedas como ¡uyyyyyy! [risas].

Por tanto, el proceso de integración no termina con que los sujetos entiendan el nuevo entorno social en el que se encuentran, sino hasta que las personas adquieren recuerdos, actitudes y sentimientos que incorporan a una vida cultural común. Nuestros entrevistados manifestaron que tras un 
proceso de aprendizaje y un mayor contacto con la sociedad receptora y la gente de la región comenzaron a sentirse cómodos en Colombia y específicamente en Bucaramanga. Al cambiar, como lo expresan ellos, su mentalidad e interiorizar su nueva realidad. Como relata Sandra: "No, no, no, no, no, ya ahora excelente, porque ya, ya, uno tiene mente, o sea, cambia la mente, como tú ya piensas como un colombiano, sí, ¡eso es muy importante”.

La asimilación al nuevo entorno solo se produce cuando los individuos no solo comprenden la cultura, sino cuando la incorporan, se apropian de ella y sienten pertenencia al nuevo territorio. Esto se ve reflejado en cómo estos sujetos después de un tiempo comienzan a expresar su pertenencia a Colombia de forma afectiva. Como relata Sandra, "yo ya quiero mucho este país, la vida está aquí”. La asimilación se da de tal forma en algunos sujetos que al volver a sus países extrañan a Colombia y quieren volver porque ya no se sienten cómodos en ellos. En la mayoría de los casos ya está tan interiorizada la cultura y ya se sienten tan cómodos que no contemplan volver a sus países, a excepción de dos sujetos que manifiestan querer dejar abierta la posibilidad de volver, pero que por el momento se sienten cómodos y no han contemplado aún la posibilidad de devolverse. Serger narra:

Yo digo que jamás un extranjero va a pensar que tú te vas vivir a un país extranjero para siempre. Entonces como te digo, los primeros, yo creo que unos tres, cuatro años uno piensa: no, un año más y me devuelvo. Pero después de los 
diez años ya te acostumbras tanto que uno ahí sí dice ¡no! Yo no vuelvo [risas], ya no te amañas allá.

Olga, por su lado, expone:

Yo aquí me sentía como una reina porque off [...] como que, qué bueno vivo después en Rusia que volví por beca, viví tres años allá en Rusia. Al volver como regular, ¿sí? Entonces ya como que al contrario ya me sentí off, mal en Rusia, aburrida... Aquí solo piscina, o sea allá no hay ni sol, bueno sí hay sol, a veces, pero piscina no, o sea me sentí como que, offf [...] Pero aquí como de una vez volví al trabajo con un sueldo bien porque ya tenía doctorado, pues me sentí muy bien. Ya era otro regreso a Colombia diferente. Extrañaba demasiado Colombia, en Rusia me sentía muy incómoda.

Este vínculo afectivo con Colombia tiene que ver tanto con la integración exitosa que tuvieron estos sujetos, con las relaciones y vínculos con colombianos, como con las experiencias significativas que han vivido en el país. En esta línea, Myriam expresa que ya no tiene vínculos con Rusia y que por el contrario sus vínculos se encuentran aquí, y que eso es lo que termina por retenerla en este país. Myriam relata:

Mira, mi circunstancia es que ya no tengo vínculos allá, ¿en qué sentido? Mis padres se murieron, solo quedan primas y ellas ya no viven en Ucrania, entonces como que hay vínculo afectivo, pero aquí. Para regresar a un edificio, a 
una casa, ya no tengo eso, sí, pero sí me gusta mucho visitar a mis familiares, pero así de regresar, no, no creo, sigo acá.

En este caso se ve cómo la asimilación se logra por medio de la relación con otros y cómo los vínculos que se generan en el país y las experiencias vividas son las que terminan por retenerla y unirla a este. En el caso de las personas que llegaron más jóvenes, no contemplan la posibilidad de salir y manifiestan sentirse demasiado cómodos en Bucaramanga. Demetrio dice:

No, yo creo que no volvería a Rusia, aquí me quedo en Bucaramanga, aquí está todo, yo creo que aquí es un lugar uno de los mejores del mundo para vivir [...] ¡Pero Bucaramanga no es tan pequeña! Bucaramanga tiene, bueno, yo creo que Bucaramanga tiene lo necesario para vivir, o sea Bucaramanga te puede cubrir la mayor parte de tus emociones que tú puedas tener [...] Bucaramanga es un paraíso.

Tania narra: “Aquí muchas cosas importantes, ¡sí! Aquí uno vive mejor, digamos en Bucaramanga, estamos en ciudad muy linda, que todo queda muy cerca, muy tranquila, ¡sí!, que tiene todo, la gente es mucho más amable, y pues, sí, aquí llevamos una vida de lo mejor”.

Pero como bien lo manifiesta Park, la asimilación no supone la anulación completa de la cultura de los migrantes, sino el sincretismo y la coexistencia de costumbres del país de origen y del país de destino, como por ejemplo la conservación de prácticas culturales alternadas con prácticas 
locales, que se ve en las comidas, en las formas de decorar sus casas, etc. ${ }^{41}$ Esta asimilación y coexistencia de prácticas $\mathrm{y}$ creencias en el individuo terminan por modificar su identidad, cuestión que veremos en profundidad en la segunda parte de este capítulo.

\section{4. "Yo soy un ruso con sabor colombiano": construcción de identidad de los migrantes soviéticos}

Teniendo en cuenta entonces que los individuos se hallan condicionados por su realidad social, la cual rige su comportamiento y formas de percibirse, al llegar a una nueva sociedad con marcas distintivas a las de su grupo de origen experimentan situaciones difíciles e inician sus procesos de integración a la sociedad receptora, donde comienzan a aprender e interiorizar costumbres, valores, creencias y, en sí, los universos simbólicos que rigen el nuevo entorno, hasta llegar a adquirir nuevos parámetros sociales e incorporarlos a su vida cultural común. Este proceso deriva en la alteración de la forma como los sujetos se perciben y son percibidos por los demás y en la alteración de sus propias identidades.

Para concluir este trabajo de investigación exploraremos cómo los migrantes terminaron por transformar sus identidades en el proceso de integración a la nueva cultura y de deconstrucción de sus imaginarios respecto al país receptor. El resultado que encontramos es que en los migrantes coexisten elementos que los atan y los identifican con sus países de

${ }^{41}$ Park, Robert. "Racial”. 
procedencia, y otros que lo atan a su país y ciudad de acogida, existiendo sincretismos dentro de ellos, generando, como lo denominó Park, híbridos raciales. ${ }^{42}$

No obstante, antes de continuar es necesario revisar el concepto de identidad con algún detalle, ya que ha sido ampliamente usado en las ciencias sociales y entendido de diversas maneras, lo que complejiza su aplicación. Hay que empezar por aclarar, como lo manifiesta Dubet, que el concepto de identidad y su uso diverso en las ciencias sociales lo convierte en "una noción que no posee unidad". ${ }^{43}$ Como lo expone Giménez, inicialmente se pensó la identidad como una cuestión meramente dada por la adscripción, es decir, como una característica inherente o heredada de los individuos, como podrían serlo el sexo o la posición social. ${ }^{44}$ No obstante, estas ideas fueron gradualmente reemplazadas por visiones menos positivistas, según las cuales las identidades son construidas mediante procesos de socialización interactivos, en los cuales los comportamientos y actitudes de un grupo determinado son transmitidos por una serie de agentes de socialización. ${ }^{45}$

42 Park, Robert. "Mentality of Racial Hybrids". The American Journal of Sociology 36.4 (1931): 534-551. Impreso.

43 Dubet, Françoise. De la sociología de la identidad a la sociología del sujeto. Toulouse: Estudios Sociológicos, 1989. Impreso.

44 Giménez, Gilberto. Identidades Sociales. México D. F.: Conaculta/Instituto Mexiquense de Cultura, 2009. Impreso.

45 Amorós, Célia. "Crítica de la identidad pura”. Debats, Institució Alfons el Magnamim 89 (2005): 62-72. Impreso. 
Para contextualizar y tener una mejor comprensión de qué es la identidad, rápidamente mencionaremos algunos de los paradigmas dominantes sobre este concepto de esquiva definición. El primer paradigma, según Sheldon Stryker, es el de la antropología, que establece que hay una fuerte relación entre la identidad y la etnicidad, en la cual la cultura relativa a una etnia es internalizada por sus individuos y posteriormente expresada por los sujetos. ${ }^{46} \mathrm{Un}$ segundo paradigma ha sido desarrollado desde la perspectiva de la psicología social, principalmente por Henri Tajfel. ${ }^{47}$ Esta conceptualización se centra en el nivel micro y en las dinámicas de grupos, ${ }^{48}$ argumenta que la identificación se produce cuando un individuo siente pertenencia a un grupo o colectivo determinado. El tercer paradigma es de la identidad colectiva. Los exponentes de esta corriente de pensamiento argumentan que los individuos, tras interactuar entre sí por periodos de tiempo más o menos prolongados, forman grupos a los cuales les asignan características, como normas, valores e ideologías. Esta corriente de pensamiento se desarrolló principalmente enmarcada en el estudio de los movimientos sociales, por algunos

46 Stryker, Sheldon y Peter Burke. "The Past, Present, and Future of an Identity Theory". Social Psychology Quarterly Special Millenium Issue on the State of Sociological Social Psychology. American Sociological Association (2000): 284-297. Impreso.

47 Tajfel, Henri. Grupos Humanos y Categorías Sociales: Estudios de Psicología Social. Trad. Carmen Huici. Barcelona: Herder, 1984. Impreso.

48 Tajfel, Henri, et al. "The Social Identity Theory of Intergroup Behavior. Political Psychology: Key readings". Political Psychology: Key Readings, Key Readings in Social Psychology. New York: us Psychology Press (2004): 276-293. Impreso. 
teóricos como Manuel Castells, Alain Touraine y Alberto Melucci. ${ }^{49}$ Por último, está el paradigma de la identidad de rol, que es un enfoque de la corriente norteamericana que establece que la identificación de los individuos se produce no solo con los grupos a los que pertenece, sino con los roles que en su vida cotidiana desempeñan. Algunos exponentes de esta corriente son Sheldon Styker y Peter Burke. ${ }^{50}$

Aunque todas estas corrientes tienen diferentes niveles de análisis y diferentes alcances, es ineludible comentar que existen ciertos puntos sobre los cuales hay acuerdos, los cuales se convertirán en pilares en el estudio aquí realizado. En primer lugar se reconoce que la identidad tiene un significado doble, ya que al mismo tiempo significa asemejarse a algo, lo cual corrientemente se expresa como identificarse con un objeto referente, situación o grupo, a la vez que significa diferenciarse de otros entes, o sea, significa estar en oposición a alguien o algo.

Un segundo punto sobre el que hay acuerdo, según Stryker ${ }^{51}$ y Bourdieu, ${ }^{52}$ es sobre la situacionalidad de la identidad, es decir que emerge y se conforma dependiendo

49 Castells, Manuel. La ciudad y las masas. Sociología de los movimientos sociales urbanos. España: Alianza, 1986. Impreso; Touraine, Alain. "Los movimientos sociales". Revista colombiana de Sociología 27 (2006):255-278. Impreso; Melucci, Alberto. Acción Colectiva, Vida Cotidiana y Democracia. México D. F.: Colegio de México, 1999.

50 Stryker, Sheldon y Peter Burke. "The Past”.

51 Stryker, Sheldon y Richard Serpe. "Identity Salience and Psychological Centrality: Equivalent, Overlapping, or Complementary Concepts?”. Social Psychology Quarter 57.1 (1994): 16-35. Impreso.

52 Bourdieu, Pierre. "La identidad y la representación: elementos para una 
de la posición social que ocupe el sujeto dentro de la sociedad. Aunque la identidad es algo que se forme dentro de los individuos, está supeditada a los estímulos provenientes de su entorno inmediato, inicialmente la familia, más adelante la comunidad.

El último punto en el que existe avenencia se refiere a que en la construcción identitaria, las opiniones que otros generan sobre los sujetos y los grupos son esenciales para que estos construyan sus propias definiciones. Esto es lo que Cooley denominó como "Self-looking glass", ${ }^{53}$ y se refiere al hecho de que durante la interacción los entes reciben información a manera de retroalimentación por parte de las personas con quienes se relacionan, información que luego es internalizada por los sujetos, convirtiéndose en referentes para su construcción identitaria.

Hasta aquí, hemos enunciado algunas de las corrientes teóricas principales acerca del concepto de identidad, aludiendo brevemente sus diferencias y similitudes. Pero, en las siguientes páginas, nos concentraremos en desarrollar el concepto de identidad ligado a la pertenencia a un grupo étnico o a una nación. Esta perspectiva resulta muy útil para explicar el caso tratado en este trabajo.

Primero es necesario tener presente que la pertenencia a una nación o a un grupo étnico supone que el individuo haya

reflexión crítica sobre la idea de región (análisis)”. Ecuador Debate 67 (2006):165184. Impreso.

53 Cooley, Charles. Human Nature and the Social Order. Illinois: The Free Press, 1956. Impreso. 
internalizado una cultura relativa al grupo nacional al cual pertenece, interiorizando y expresando sus prácticas, apropiándose de sus valores y símbolos, así como de su historia y su presente. Por tanto, hay que comenzar esta discusión aclarando que, contrario a lo que se creía en la antropología clásica, la identidad étnica no depende del aislamiento de un grupo, ni es el resultado inmediato de compartir una cultura común. La identidad no es una categoría adscriptiva que dependa simplemente de compartir una nación, sino que se conforma y depende de cómo los miembros de un grupo étnico muestran rasgos particulares de esa cultura que los diferencian de aquellos grupos con los que interactúan. Barth denomina estas diferencias como límites o fronteras entre grupos étnicos. ${ }^{54}$ Las identidades étnicas se generan en procesos de interacción con otros grupos, en dinámicas de inclusión-exclusión, y no en la ausencia de contacto con otras culturas.

Los planteamientos de Barth resultan muy útiles para el caso aquí tratado, pues hizo un aporte al conocimiento sobre la etnicidad y la identidad étnica centrado en las relaciones intergrupales. ${ }^{55}$ En la antropología clásica se argumentaba que la identidad étnica se construía por características, valores, creencias y elementos de una cultura que permanecían inmutables y se trasmitían de generación en generación. En contraposición, Barth desplaza el estudio de la etnicidad a las relaciones entre grupos y al mantenimiento de fronteras,

54 Barth, Frederik. “Los grupos”.

55 Ibid. 
determinando que más allá de la permanencia de rasgos culturales invariables y permanentes, la manutención de un grupo étnico en el tiempo se da por la existencia de fronteras que los diferencian con otros grupos y que son validadas en la interacción social. ${ }^{56}$

De la misma manera, Bourdieu manifiesta que la construcción identitaria es algo estrictamente relacional e interactivo, elaborada en gran medida a partir de las percepciones de los otros sobre el grupo con el cual el sujeto se identifica. ${ }^{57}$ Como lo manifiesta Bourdieu, a través de los estereotipos o estigmas de un grupo a otro se dan luchas por clasificarse en la estratificación social. Así, los grupos refuerzan las marcas distintivas de otro, con el fin de imponer principios de división y de clasificación en la vida en sociedad. De esta forma, los estigmas se vuelven entonces elementos claves para fortalecer la identidad y pertenencia a un grupo. ${ }^{58}$

El primer punto que tendremos presente para nuestro análisis, haciendo eco de lo planteado por Barth y Bordieu, es que la identidad étnica o nacional es formada mediante el proceso de socialización y, en el caso de la migración, de la resocialización que mencionamos anteriormente. La identidad de una nación, es importante tener claro, se genera en la interacción con otros grupos.

Un segundo punto, eje de nuestro análisis, es que, tal como lo manifiesta Barth, las identidades étnicas no son fijas e

\footnotetext{
56 Ibid.

57 Bourdieu, Pierre. "La identidad".

58 Ibid.
} 
inamovibles, por el contrario, son susceptibles de transformarse de manera constante. ${ }^{59}$ Los aspectos culturales que determinan la diferencia entre grupos pueden cambiar sin dejar de existir una dicotomía entre miembros y extraños. Por tanto, en la interacción con otros, algunos rasgos culturales propios de un grupo se mantienen como señales y emblemas de diferencia, otros son pasados por alto, otros, consolidados al asimilar rasgos de la nueva cultura y otros, en algunas relaciones, negados. La identidad está en constante cambio y constante negociación, hecha de mutaciones y permanencias organizadas alrededor del ideal del grupo.$^{60}$

Sin embargo, reiteramos, como lo manifiesta Barth, que no es todo el conjunto de normas o costumbres que un grupo encierra lo que define la identidad étnica, sino las fronteras que este grupo tiene frente a otros. Barth asegura entonces que una frontera étnica puede permanecer en el tiempo a pesar de los cambios culturales y de la apropiación de nuevos valores. Él argumenta que son las fronteras mismas y la capacidad de mantenerlas en la interacción con otros grupos lo que define la identidad, y no los rasgos culturales seleccionados para marcarla, en un momento dado. ${ }^{61}$

Después de delimitar nuestro marco analítico, intentáremos en las páginas que restan entender cómo este grupo de inmigrantes, a través de la interacción con la sociedad

\footnotetext{
59 Barth, Frederik. “Los grupos”.

60 Ibid.

61 Ibid.
} 
receptora, establece sus fronteras y las hace evidentes, al mismo tiempo que ve su identidad alterada.

\section{5. "Yo chupé teta de madre ucraniana": identidad soviética}

\subsubsection{Hacia una identidad soviética}

En el caso particular aquí estudiado, aunque no podamos hablar de una comunidad de soviéticos en un sentido estricto, puede aplicarse a estas personas lo que Barth expone de manera más general como las características de un grupo étnico, en el sentido de que "comparten valores culturales fundamentales" ${ }^{\prime 2}$ y "tienen una membresía que los identifica y les permite ser identificados por otros". ${ }^{63}$ No podemos decir que las características étnicas influyan en la organización de los inmigrantes en términos espaciales como lo propone Barth, aunque sí es cierto que "utilizan algunas de sus características culturales como emblemas para diferenciarse" 64 grupalmente, tal como la conformidad con ciertos valores como la intelectualidad y el uso de ciertos artefactos materiales. En suma, lo que podríamos concluir es que existe una conciencia sobre la existencia de los grupos nacionalesétnicos, pero en la realidad, como aseveramos, lo que se evidencian son pequeñas redes fragmentadas de migrantes, entre las cuales no hay muchos contactos, ni los contactos
62 Ibid.
63 Ibid.
64 Ibid. 
que hay son muy significativos ni prolongados. Todos estos puntos los desarrollaremos en las páginas siguientes de esta sección. Hablar de identidades étnicas para este grupo específico de inmigrantes es aún más complejo, pues, como lo hemos expuesto, una vez la uRss colapsó se dio paso a la construcción de nuevas naciones y al esfuerzo de los nuevos Estados por construir identidades nacionales basadas en gran parte en la pertenencia étnica; por tanto, el objeto referente de las identidades era doble, era étnico y nacional. ${ }^{65}$ Cabe traer a colación el planteamiento de Andrés, que si bien se refiere al caso particular de los ucranianos, podría extenderse a otras de las nuevas naciones:

La identidad de los ucranianos se construyó después -después de la desintegración de la URss-, imagínese, querían crear un país donde antes no había, eso era muy difícil porque era un país donde el idioma oficial-después de la caída- era el ucraniano, pero solamente como el $30 \%$ de las personas lo hablaba, los demás hablaban ruso.

Esto indica que, por lo menos antes de 1991, hablar de identidades nacionales podría resultar falaz, porque aunque existían movimientos secesionistas nacionalistas en diferentes repúblicas, estos eran minoritarios, y solo tomaron verdadero carácter y resonaron a finales de la perestroika y después de ella con la fragmentación en unidades políticas

65 Pilkington, Hilary. “Migration”. 
nacionales. ${ }^{66}$ Sin embargo, el cambio de límites espaciales no supuso de inmediato el cambio de identidad étnica o nacional, pues como lo hemos argumentado, la identidad étnica o nacional no es adscriptiva y no depende de límites espaciales. Así, durante la época en que se produjeron las migraciones aquí estudiadas resulta complicado hablar de unas identidades postsoviéticas. Este hecho se ve reflejado en que las personas entrevistadas en esta investigación no presentaron su identidad de una manera clara, sino como una amalgama de identidades entre lo soviético de manera general e identidades propias a sus naciones, en este caso Ucrania y Rusia, con marcado predominio de lo soviético, cuestión que se hace expresa en la respuesta reiterativa de varios entrevistados. Cuando preguntamos sobre su pertenencia y la conformidad con la forma en que denominan en Bucaramanga a rusos, ucranianos y polacos bajo el apelativo general de rusos, muchas veces contestaban "ruso o ucraniano, da igual”. Esto se ve claramente en el discurso de Ana, quien es ucraniana. Al referirse a una amiga rusa se identificaba con ella bajo el apelativo de soviética, sin embargo hizo la diferencia entre rusa y soviética, lo cual demuestra la complejidad de la identidad étnica de estos sujetos: "Fue una paisana mía, no mía, sino de unión soviética, vamos a hablar de Unión Soviética, vamos a hablar, ella es de Rusia, no es ucraniana, pero en fin pues paisana, soviética [...]”.

El hecho de que estos inmigrantes rusos y ucranianos se denominen aún como soviéticos y esta sea la categoría

66 Ibid. 
nacional que cubra a algunos en sus relatos, además de deberse a la historia de sus naciones, podría deberse a que esta identidad soviética se reafirmó al llegar a Colombia y particularmente a la ciudad de Bucaramanga, donde la gran categoría de nación soviética se sobrepuso por encima de las regiones. Sin embargo, en este caso vale la pena recordar lo propuesto por Bourdieu: la identidad y los apelativos de un grupo también dependen de la forma en que estos son vistos por los otros. Al llegar a una ciudad donde todos son denominados por la sociedad receptora como rusos, sin importar que su país de procedencia no lo sea, genera que estos mismos hayan empezado a identificarse verbalmente como tales, tal como lo refiere la frase de Ana: "ruso o ucraniano da igual", punto en el que ahondaremos más adelante. Para simplificar nuestro análisis, nos referiremos a la identidad que las personas habían formado en las repúblicas soviéticas y las emergentes e incipientes postsoviéticas como identidad soviética y a la identidad que las personas construyen en el país y la ciudad receptora como identidad colombiana.

\subsubsection{La importancia de los otros}

\section{en la construcción de la identidad}

Como se ha manifestado, uno de los puntos en los que existen acuerdos alrededor de la identidad es en el hecho de que esta se construye en relación con los otros. Sin embargo, en el caso de los inmigrantes, la cuestión de la alteridad es más implacable. No solo se reflejan, siguiendo la metáfora del 
espejo de Cooley ${ }^{67}$ en otros que han atravesado procesos de socialización similares y han construido identidades nacionales análogas, sino que se comparan con otros que han sido socializados en culturas con pautas y valores que pueden ser radicalmente diferentes, incluso opuestos.

En la línea de Barth, la identidad soviética para este caso puede entenderse como la conformidad y aceptación de valores, prácticas, preocupación con sus lugares de origen y con las cuestiones relacionadas con el mundo soviético. Esta identidad solo se hace notable para ellos mismos en el momento en que son expuestos, por así decirlo, a un espejo que es la sociedad colombiana, donde además de encontrar pautas culturales diferentes, descubren límites culturales que refuerzan su identidad. En este contexto abordaremos la cuestión identitaria. La percepción del inmigrante como otro es un referente importante en la construcción de su identidad. Esto se evidencia en el hecho de sentirse como diferentes y al ser percibidos como tales. Como lo refiere Serger:

Desde que usted llega, ipum! Se encuentra una barrera. Es que imagínese un man como de dos metros caminando con cara de perdido, bien blanco, como que no cuadra [risas]. Entonces la gente lo mira como 'uyy, tan raro ese man', y usted siente eso, que usted no pertenece aquí, como quien dice: usted y yo no somos iguales, y yo prefiero respetar ese límite.

${ }^{67}$ Cooley, Charles. "Human”. 
$\mathrm{Al}$ enfrentarse a una sociedad con unas normas y, en general, una cultura, diferentes, los migrantes pueden apreciarse a sí mismos en otra dimensión más englobante como la pertenencia a una nación. Este refuerzo a sus identidades nacionales no se hace por un simple reflejo del individuo, las personas del lugar de destino tienen un rol fundamental en la construcción de las identidades de los migrantes. Tal como lo expone Bourdieu, las personas del grupo mayoritario se vuelven puntos de referencia importantes en la medida que le indican a nuestros entrevistados quiénes son. ${ }^{68}$ Lo hacen utilizando estereotipos, estigmas, etiquetas y palabras para nombrarlos como rusos, y asociando a ellos ideas estereotipadas. En este caso particular, esto resulta muy interesante, pues ser denominados como rusos por la sociedad receptora hizo que estos mismos, en algunos casos, se definieran como tales, sin importar que no provinieran propiamente de Rusia. Ana, por ejemplo, siendo ucraniana, manifiesta: "Yo ya estoy acostumbrada a que en la universidad nos digan los rusos de la facultad $\mathrm{X}$ y cuando me preguntan si soy rusa yo digo que sí, me da pereza explicar que no soy".

Una de las maneras estereotipadas bajo las cuales los inmigrantes soviéticos construyen sus identidades está relacionada con uno de los grandes valores que suele asociárseles: la educación, la intelectualidad y la disciplina. Tania narra: "Lo que sí tiene el ruso y el ucraniano es sí son muy inteligentes $[\ldots]$ mi amiga ucraniana habla polaco, ruso, francés, español e inglés, ¡imagínese! Habla seis idiomas, ¿sí ven? Es la

68 Bourdieu, Pierre. "La identidad". 
parte como intelectual”. Nina también narra que la perciben como diferente gracias a su disciplina y vocación al estudio.

¿En mi vida diaria? ¡No! Yo pienso que no es porque yo lo digo, sino porque los mismos colombianos ven eso, ¿no? O sea, que uno es muy cumplido, que uno muy dedicado, muy entregado a la lectura, al estudio, que eso no lo encuentran, digamos que en personas colombianas, ¿no? Eso definitivamente lo marca a uno porque es como más estricto o mucho más disciplinada en muchas cosas que los colombianos.

En cuanto a la intelectualidad, entendida como el capital cultural, como la formación e instrucción no académica, es necesario mencionar que la participación y la vinculación estrecha en los circuitos culturales pueden ser vistas como una forma de acumulación de capital cultural y reproducción de valores por los inmigrantes. Esto puede ser entendido como un refuerzo positivo para sus identidades. Esto se evidencia al observar el hecho de que varios asisten como espectadores frecuentes a recitales, teatros, etc. Los profesores de música de la universidad $\mathrm{X}$ acostumbran a participar de eventos como festivales y recitales de piano y Serger, por ejemplo, participó de una de las bandas de rock más populares de la región en este momento.

La valoración un tanto idealizada de la intelectualidad no se hizo explícita solamente durante las entrevistas ni la observación, sino en el trabajo de archivo de revisar sus currículos 
académicos. ${ }^{69}$ Como hemos mencionado en otros apartados, todas las personas que participaron en esta investigación y todas las personas que nos referían que no se incluyeron en este estudio habían obtenido titulaciones de altísimo nivel y desarrollaban sus vidas en torno al ambiente académico. Pero la cuestión no se limitó a eso, retomando el caso de los más jóvenes, encontramos que en sus proyectos de vida, una parte importante tiene que ver con el proyecto educativo. Por ejemplo Demetrio, quien tiene menos de 25 años, está formando su proyecto de vida en torno a la educación: una vez egresó del colegio inició su pregrado, enseguida la maestría y al acabarla iniciará sus estudios doctorales. El caso de Demetrio puede resultar atípico en Colombia, porque aunque cada día los proyectos de vida relacionados con la educación son más comunes, aún son muy pocas las personas en el país y en la región que retrasan su inserción completa en el mercado laboral para continuar en la educación formal, y que elaboran sus proyectos de vida en relación con la educación extensa. Igualmente, Tania y Nina han construido proyectos de vida en gran parte asociados a la educación. Es posible correlacionar la influencia de sus padres como algo decisivo en la conformación de estos proyectos, pues ambos se han dedicado a la labor académica. Al respecto Demetrio narra, "es que yo quiero seguir estudiando, es algo que viene de familia, sí, papá no me perdonaría [risas] que parara de estudiar y yo tampoco, me sentiría como fracasado, ¿no?”

69 Sus CvLAC fueron revisados. Disponibles al público en los sitios web oficiales de Colciencias. 
Como bien lo manifiesta Barth, no es todo el conjunto de normas culturales las que definen un grupo étnico, sólo los factores que para los individuos son socialmente importantes pueden ser considerados como diagnósticos para sus miembros y elementos que denotan identidad. ${ }^{70}$ Es el límite étnico lo que define al grupo y no el total del contenido cultural que este encierra. De esta manera, es notorio cómo la intelectualidad, la disciplina y la responsabilidad son mencionadas por la mayoría de los entrevistados como características culturales que mantienen y no están dispuestos conciliar y que los identifica como rusos o ucranianos y los diferencia de la comunidad receptora.

\subsubsection{Socialización e identidad: dos procesos simultáneos}

Además de la importancia de los otros en la formación de la identidad, como lo manifiestan Bourdieu, Barth y Cooley, hay que tener en cuenta que los procesos de socialización primaria, como lo mencionábamos al comienzo de este capítulo, son fundamentales en la formación de la identidad de los sujetos. Gracias a estos procesos de socialización los sujetos se identifican y se vinculan a sus países de origen a pesar de haberse integrado de manera satisfactoria a la cultura colombiana. Todos los entrevistados coinciden en afirmar que aún existe un gran vínculo con Rusia o Ucrania, y que su identificación con sus naciones ocupa un lugar preponderante en sus vidas a pesar de haber vivido por fuera de sus países

70 Barth, Frederik. “Los grupos”. 
durante un tiempo considerable. Este hecho es evidente en varias de las afirmaciones siguientes: Myriam, quien migró en una edad adulta dice, "pues siempre será mi patria, ¿̇me entiendes?, recuerdos, siempre hay alguien, padres, familia, todos y esos vínculos siempre se quedan. Niñez, si uno como tiene sus etapas de vida y eso se queda grabado, hay un vínculo, quieras o no quieras".

Nina, quien viajó a Colombia al final de su adolescencia, a pesar de haber vivido más años en Colombia que en su natal Rusia, afirma,

Yo soy rusa. Es que no es que uno se desvincule totalmente, sino que uno mira, bueno, pero por ejemplo si hay unos olímpicos, Rusia en qué puesto va, cuántas medallas de oro llevan [...] no se desvincula uno totalmente, sino sigue, como, ¿qué ha pasado con su país? Sí. Es que uno no se puede olvidar del país en el que creció.

Aunque estos sujetos comprendan mejor las normas culturales del país receptor, ahora casi 10 años después de su migración, y hayan asimilado algunas de sus costumbres, siguen reconociéndose como rusos, ucranianos o soviéticos y hablando con nostalgia de su país y sus costumbres.

De acuerdo con la idea de Berger y Luckmann, el hecho de que las identidades nacionales aún se mantengan tan firmes a pesar del paso del tiempo también tiene que ver con haber pasado por procesos de socialización temprana en la 
región soviética. ${ }^{71} \mathrm{Su}$ primer mundo, su lengua madre, sus primeros recuerdos y sus más fuertes valores, muchos asociados a los vínculos familiares, relacionados con su país de origen, a pesar de su permanencia por fuera de la nación, permanecen inquebrantables. Por el contrario, en aquellos migrantes que llegaron a edades muy cortas, como el caso de los hijos de Myriam y Ana, de aproximadamente 10 años, su identidad y pertenencia se hallan más arraigadas al país de acogida, porque sus procesos de socialización primaria se dieron en él. Ana, por ejemplo, narra: “¿Mi hijo? El sí es colombiano, él me dice: si quiere váyase, pero sola”. Myriam, por su parte, comenta: "Ucrania solo permite una nacionalidad, yo soy ucraniana y mi hijo era, pero cumplió 18 y dijo para mí: no, mamá, yo soy colombiano y renuncio a la nacionalidad ucraniana". En este último caso, de nuevo sale al relieve el vínculo existente entre la nacionalidad legal que se ostenta y la identidad que se posee.

En este punto es válido aclarar que aunque podría pensarse que la identificación con una categoría nacional o étnica tiene que ver simplemente con el tiempo de permanencia en un grupo o una nación, de tal manera que entre mayor sea el tiempo de influencia del objeto mayor es la identificación, el tiempo no puede ser visto simplemente como el tiempo cronológico. El tiempo en este sentido tiene que ver con la posibilidad de tener más experiencias significativas para los sujetos, de desarrollar vínculos más fuertes, estables y perdurables con lo nacional. Si tenemos en cuenta este hecho,

71 Berger, Peter y Thomas Luckmann. "La construcción”. 
se torna evidente que la sedimentación de la identidad varía de acuerdo con el ciclo vital. Las personas que migraron a edades más tempranas desarrollaron identidades colombianas más fuertes debido a que tuvieron la probabilidad de vivir mayores cantidades de experiencias significativas en Colombia. Por otra parte, aquellos que tuvieron su socialización primaria en sus países de origen, además de enfrentar procesos de integración al nuevo entorno más complicados, tienen una identidad soviética mucho más notable.

Para el caso de personas que viajan adultas a Colombia y que, por tanto, tuvieron su socialización primaria en su país de origen, resulta evidente el hecho de que migrar supuso un refuerzo de sus identidades o, por lo menos, la toma de consciencia sobre las mismas. Tal aseveración la hacemos basados en que su propia percepción como pertenecientes a otra nación se hizo más fuerte al abandonar sus áreas de origen y enfrentarse a un nuevo lugar, con costumbres que, como vimos, les resultaban inicialmente extrañas. En este sentido, Ana narra: "Yo creo que uno empieza a sentirse más ucraniano o perteneciente a alguna nacionalidad en particular cuando viene a otro país”. Antes de la migración las identidades étnicas pueden ser resultados de la socialización primaria en el país en que se nace, de manera que pueden ser hasta cierto punto irreflexivas, basadas en normas consuetudinarias, pero al entrar en contacto con la sociedad receptora, tales características son dejadas de lado para entrar en un proceso consciente de definición. Como lo expone Barth, se entra en un proceso de reconfiguración de su identidad donde se concilia entre lo que se adquiere y lo que se 
mantiene. ${ }^{72}$ Cooley converge en que la identidad puede ser hasta cierto punto irreflexiva, es decir, mientras se está en la zona de origen, rodeado por personas similares y con una cultura común, los valores, creencias y prácticas relacionadas con esa identidad permanecen como algo latente y poco evidente para los sujetos, pero se torna reflexiva y plenamente consciente para los sujetos cuando es confrontada, cuando es puesta frente a un espejo que la refleje. ${ }^{73}$ Ese espejo no es otra cosa que la sociedad que los recibe.

Barth asegura que el arraigo a un lugar y a una identidad que no pertenece a la del grupo mayoritario se debe a unos elementos que le permiten a los sujetos identificarse con su país, sin importar que en muchos de los casos estos elementos se queden en el plano de lo mítico. ${ }^{74}$ En este caso particular encontramos que existen elementos de identificación intangible y tangible. Los intangibles, como en el caso de Nina, quien manifiesta que la intelectualidad es un valor, un rasgo profundamente soviético: "Es que los rusos y ucranianos, es decir soviéticos, logramos lo que queremos, somos gente muy inteligente, muy intelectual". Y los tangibles, que se hacen manifiestos, por ejemplo, como notamos en la observación de sus hogares y lugares de trabajo, con el uso de artefactos que hacen parte de la cultura material, como las muñecas Matrioshkas o Mamushkas, los cuadros hechos con

72 Ibid.

73 Es importante recordar que Charles Horton Cooley anotó que la construcción del Self y la consciencia del yo únicamente se daba al confrontarse con espejos, que no son otra cosa que la propia sociedad. Cooley, Charles. "Human”.

74 Barth, Frederik. “Los grupos”. 
corteza de abedul o los libros en sus idiomas nativos, que encierran significados simbólicos y míticos que los anclan a su identidad soviética.

\subsection{4. "Nunca dejarás de ser de allí, tu pasaporte te lo recuerda"}

Además, es relevante mencionar la importancia de conservar legalmente su nacionalidad y los papeles que los certifican como rusos o ucranianos, como emblemas de su identidad, tal como lo relata Ana: "nunca dejarás de ser de ese país, es que tu pasaporte, tu marca dice que tú eres de allá y siempre tendrás que reconocer que tú eres de allá”. Del mismo modo, Myriam recalca, "es que no puedo tener la nacionalidad colombiana, porque Ucrania solo permite una, ¿y cómo voy a renunciar a mi patria? No puedo, es que yo pertenezco allá". Serger también comenta, "es que tener nacionalidad colombiana es una mentira, cómo voy a dejar de ser ucraniano, eso sería traicionar a mi patria, negar lo que soy". Así, el vínculo con su país de origen está claramente ligado a aquellos documentos que certifican su pertenencia. Estos documentos se vuelven relevantes a la hora de afirmar su identificación con sus países y su pertenencia, sin importar que hace años no visiten sus países ni que, en algunos casos, ya no se sientan cómodos en ellos. Los documentos que los relacionan a sus países de origen son referentes clave a la hora de definir su identidad étnica o nacional, no solamente ligada a cómo los sujetos son identificados por otros, sino a cómo son reconocidos legalmente. En este punto se podrían concentrar estudios posteriores. 
Es notorio en todos los casos que aunque existe un vínculo muy fuerte con sus países de origen, gracias a los procesos de socialización que vivieron en ellos, también es evidente un vínculo con Colombia que se generó en sus procesos de integración y por tanto de resocialización. En línea con esto, Serger narra: "Yo ya me amaño aquí, yo ya me acostumbré a esta vida, yo ya soy un poquito colombiano", pero a la vez expone, "yo chupé teta de madre ucraniana, yo soy ucraniano". Esta doble identificación es una constante en el grupo de migrantes aquí estudiados. Aunque estos sujetos manifiestan un fuerte sentido de pertenencia a sus áreas de origen, también es común encontrar frases como "cuando voy a Rusia, sí la pasó bien, pero ya no es lo mismo, ya extrañas tu casa aquí”. Como dice Isabela: "Me costó mucho trabajo, yo ya me adapté [risas] ya al ir allá me siento distinta".

Como lo explica Barth, esta dualidad de sentirse pertenecientes a sus países de origen, pero de estar adaptados a la cultura receptora, se debe a que los sujetos pueden modificar sus costumbres y adoptar los rasgos que les presenta la nueva cultura, manteniendo al mismo tiempo su identidad nacional y sus fronteras étnicas establecidas. Según Barth, un grupo étnico puede adoptar rasgos culturales de otros grupos, como la lengua, su forma de comer, de vestir, pero continuar percibiéndose como distinto. ${ }^{75}$

Hasta este punto analizamos cómo la identidad de sus naciones de origen se presenta, y cómo se mantiene ya dentro de Colombia. No obstante, en las próximas páginas debemos

75 Ibid. 
ilustrar cómo estas personas construyen su identidad con la nación receptora, cómo se forma ese vínculo profundo que les permite tener como segundo objeto referente a Colombia. Después abordaremos en detalle cómo conviven estas dos identidades.

\subsubsection{Hacia una identidad colombiana}

El asunto de la doble identificación con nacionalidades es posible, considerando que pueden existir múltiples identidades, aunque sean contradictorias o divergentes. En esta línea Barth comenta que "la interacción entre grupos étnicos en un sistema social multiétnico no conduce a la aniquilación a través del cambio y la aculturación; las diferencias culturales persisten a pesar del contacto y la interdependencia". ${ }^{76}$ Es este el proceso que observamos en este caso. Como veremos en algunos puntos, las identidades nacionales previas suelen ceder, aunque no ceden del todo. Para este caso lo que vemos es la identificación de estos sujetos con dos categorías nacionales, la Unión Soviética y Colombia, que se ajustan y se negocian entre sí. Tal como lo manifiesta Barth, "cuando interactúan personas pertenecientes a culturas diferentes es de esperar que sus diferencias se reduzcan, ya que la interacción requiere y genera una congruencia de códigos y valores; en otras palabras, una similitud o comunidad de cultura". ${ }^{77}$ A continuación mostraremos cómo la identidad de estos sujetos se moldea en un proceso doble, el de la construcción

76 Ibid.

77 Ibid. 
de la identidad colombiana y el de las transformaciones de su identidad soviética. Estos procesos se llevan a cabo de dos maneras, primero en sus vidas cotidianas en la ciudad receptora, y segundo, en el momento en que retornaban a sus áreas de origen.

La incorporación de nuevos elementos para la construcción de sus nuevas identidades -valga la redundancia-como colombianos se dio en la vida cotidiana, hasta hacerse manifiesta su incorporación hasta en los detalles más mínimos y en los espacios más íntimos. Serger narra un incidente que aconteció en su vida diaria con el uso del lenguaje: "Una vez llegué a la casa y me quedé quieto, porque estaba pensando en español, no, ¿qué me pasa hombre? Cogí el primer libro que había en ucraniano y empecé a leer en voz alta para no olvidar idioma, una cosa nostálgica”.

La frase de Serger evidencia no solo el crecimiento de la importancia del español en la comunicación consigo mismo y su incorporación en un nivel muy profundo, sino la crisis que le provocó y la necesidad de resolverla acudiendo a estrategias para mantener su identidad ucraniana ante la percepción de que esta se encontraba en riesgo. Además podemos ver el tono afectivo y emocional que envuelve el hecho de que la frase se formule como algo nostálgico.

Como es manifestado por Bourdieu, "todos los universos cambian porque son productos históricos humanos. Esos cambios son producidos por las acciones concretas de los seres humanos". ${ }^{78}$ Así, en el caso de los migrantes, la sociedad

78 Bourdieu, Pierre. "La identidad". 
cambia con el paso del tiempo y más en el caso de estos migrantes, cuyas naciones eran socialistas o se encontraban en la transición del socialismo al capitalismo cuando partieron. Estas naciones tuvieron un radical cambio económico, político y social en un tiempo acelerado, de tal manera que al retornar a sus áreas de origen se encontraran con una realidad completamente distinta a la que dejaron. Encontraron que los países a los que deseaban regresar habían cambiado y que los lugares que añoraban habían quedado detenidos únicamente en sus recuerdos, como espacios imaginados. Como lo manifiesta Barth, esos lugares que se añoran, aunque refuerzan la identidad, generan grandes conflictos en los sujetos.

El momento mismo del retorno a sus lugares de origen es cuando este cambio identitario se tornó más patente y fuerte. De la misma manera que ellos, apenas llegaron, se percibieron como distintos al reflejarse en el espejo que fue la sociedad bumanguesa, una vez retornaron a sus patrias experimentaron un sentimiento similar. A pesar de que con quienes se encontraban eran de facto los mismos lugares y las mismas personas con quienes previamente habían formado vínculos fuertes, estos eran percibidos de manera diferente, con cierta extrañeza. Sobre todo porque en el momento en el que partieron, tal como mencionamos antes, las identidades nacionales se encontraban subyugadas a una identidad soviética más o menos definida, y al volver encontraron no sólo países con una nueva identidad nacional-étnica, sino con el cambio de un país socialista a uno capitalista y con personas adaptadas a estos nuevos parámetros.Serger plantea, 
al principio, la primera vez que yo fui no fue difícil, la última ya es como, o sea [...] me fui por tanto tiempo, mis amigos que quedaban ahí pues ya vivían distinto, además que las cosas que llegaron nuevas, que entraron económicamente, políticamente, socialmente, o sea, ha cambiado mucho el ambiente y yo me llevaban pa' allá, pa' acá, pero yo, solo, pues [...] con la gente como que no, no me sentía cómodo.

Serger pone en cuestión el hecho de que las personas que en algún momento fueron sus significantes más inmediatos, por virtud del paso del tiempo, se tornaron en extraños. Es relevante como él lo cuenta, que en el primer viaje, que realizó a los pocos años, no fue tan difícil, mientras que en el último la sensación fue completamente distinta. Esto puede deberse a que para esa segunda ocasión -cinco años despuésya había incorporado y desarrollado una identidad con Colombia más fuerte que la primera vez, y su integración ya era latente, de tal manera que el contraste resultó más marcado.

Serger continúa su narración haciendo una acotación a la lengua y el aprendizaje:

Cuando fui la última vez, fuimos con mi hija a comprar un equipo, un computador, ¿no? Yo lo aprendí así en Colombia en español todo, nunca lo pensaba como en ruso, hasta ahora, pues los navegadores de internet los refiero en español que en ruso, y llegamos a comprar y hasta un detalle me acuerdo, yo dije, “ ¿y el modem?”, y 
la vieja como “¿Qué?, ¿modem?” O sea, la misma palabra y las otras que son traducidas, ¿ ¿í? Casi no me entendía, yo le dije, “muestre el papel, yo entiendo ahí mejor, ¿ ¿í??.

Esta cita no solo refuerza la idea del entorno cambiante, sino también indica que en un momento un punto referente como el lenguaje natal cedió predominancia, lo que muestra que la socialización posterior de este individuo se hizo basada en una estructura simbólica asociada al lugar de su nueva vivienda.

Lina cuenta en un tono similar su experiencia de retorno: "Durante tres años regresé una vez, como para vacaciones, quería venir, pues estaba como dos meses en vacaciones también, ¡no!, ¡extrañaba demasiado Colombia! En Rusia me sentía muy incómoda”. A pesar de que se encuentran en sus lugares natales con quienes habían sido sus vínculos más significantes, perciben que sus identidades soviéticas no son inmanentes y han mudado:

En 2007 estuvimos ahí, fuimos de vacaciones un mes, un mes largo que estuvimos allí y de ahí encontré con amigas del colegio algunas, con mis familiares, pero tú ya te sientes que no eres de allá, ¿sí?, ya ha cambiado totalmente, la gente vive en una cultura distinta que tú sientes como que ya volver a acoplarse a todo eso no será fácil y ya estás como establecido en una parte que comprendes mejor y no es, como decirte, tú esto yo me quiero devolver allá. 
Pero el relato de Lina no se detiene ahí, ella comenta: "Sin embargo, tú toda la vida vas a sentir que tú eres ruso, ¿ sí?”. Este hecho se presenta como un leitmotiv, porque la coexistencia de las identidades es contingente, los lazos afectivos con las personas y las imágenes, a veces fijas y del pasado, son perennes y residen en el interior de las personas con notable vínculo afectivo, de manera que la ambigüedad entre pertenecer y no pertenecer es un sentimiento repetitivo.

La crisis aparece como un momento en el que las identidades no se ajustan y entran en conflicto, aunque este hecho no es expresado con tanta vehemencia ni es tan recurrente, de facto, es importante mencionarlo, fue sólo expresado por pocas personas. Serger, de una manera muy emblemática, dijo: "Yo chupé la teta de madre ucraniana [...] yo siempre voy a sentir la diferencia física, anatómica, pues [...] para mí sería una mentira, algo falso, y allá todos me van a mirar como un traidor".

\subsection{6. "Ya tengo cédula, soy colombiano": identidad colombiana}

La identidad nacional colombiana emerge después de haber pasado por los procesos de socialización descritos en la primera parte de este capítulo. Encontramos que algunos de los sujetos construían sus identidades colombianas basados en parte en sus propios imaginaros, en sus percepciones y en cómo veían a las personas de la ciudad y el país receptor, basados fuertemente en los estereotipos y estigmas que asumían que caracterizaban a las personas de las áreas de llegada. Dicho proceso lo mostraremos a continuación. 
Ciertamente, salta a la vista el hecho de que la construcción de la identidad colombiana se relaciona con los imaginarios que los migrantes tenían de lo que son los locales y los atributos que estos tenían, en gran medida divergentes a los suyos; tal es el caso de la procrastinación, que coloquialmente referían como pereza, y que en este caso se posicionó como antónimo de la intelectualidad. La identidad como colombianos se construyó guiada por la idea de la alteridad con la identidad soviética. En ese orden de ideas, notamos que uno de los más fuertes valores atados a la identidad soviética es la intelectualidad, valor que, según nuestros entrevistados, no es tan fuerte en Colombia. Por ejemplo, Demetrio relataba: "Los compañeros se reían porque a veces mi papá reclamaba porque no avanzábamos mucho en esa clase como él quería", mientras él mismo refería que ya le daba pereza estudiar tanto. Igualmente Tania afirma, "Uno a veces quisiera tener esa verraquera, pero uno ya es muy colombiano, muy colombiano, duerme más horas y todo eso, ¡no! Todo lo hace como a su medida, ¡no! Ya es más perezosito”. Los individuos que demuestran fuertes identidades colombianas arguyen, por ejemplo, que no son tan estudiosos como los soviéticos.

El imaginario del subdesarrollo, de la incapacidad técnica y de la ineficiencia que antes de partir se presentaba como un aspecto sumamente negativo, una vez pasado algún tiempo no es simplemente deconstruido, sino que es incorporado como parte de la nueva identidad colombiana. Los estereotipos y estigmas del otro son apropiados por los 
inmigrantes como un elemento constitutivo de sus identidades. Cuestiones como la impuntualidad, que desde el punto de vista de un colombiano no generan conflicto y pueden ser trivializados, y que para los inmigrantes en un principio resultaron problemáticos, con el correr del tiempo fueron perdiendo su carácter de problema y pasaron a ser interiorizados. Como bien lo expresa Ana, "ya me acostumbré un poquito, porque uno no puede mover la pared, o se va a chocar siempre con la pared, pero mover la pared es imposible, luchas con los alumnos; es luchar toda la vida, entonces a uno le toca acomodarse, es como chocarse con una pared muchas veces”.

Siguiendo esta idea, son varios los ejemplos que pueden ser citados, pero todos concluyen en el hecho de que aunque en principio fue difícil adaptarse a esta situación, con el tiempo comenzó a ser valorada. La impuntualidad dejó de ser apreciada como una carencia, como la falta de productividad, para ser valorada como una forma alternativa de vivir la vida, como otra realidad posible. Sandra lo expresa como una cuestión de vivir más aliviada y no tener tanto estrés,

soy como colombiana, sí, sí, porque reunión a las 8 me voy a las 8:15 [risas] y todavía estamos esperando a la gente entonces ese me pareció como terrible [...] y ya ahora, ya más relajada, más esto, no tanto estrés por las cosas [...] son colombianos, su lugar está en Colombia y el mío también, el Moscú es muy estresante [risas] aquí es más tranquilo, muchos festivos, ¡uyy, tan rico!, ¡uy, por ejemplo este lunes 
es festivo!, ¡ay tan rico! [risas] tú puedes descansar, hacer tus cosas personales, sí es chévere.

Serger agrega, "por eso los colombianos viven más años”.

En la identificación también está presente el elemento de reconocer a los colombianos y reconocer a los soviéticos que habitan sus áreas de origen, los que no migraron, hasta cierto punto como extraños. Esto se descubre al analizar que en algunos discursos dicen "los rusos son" en lugar de decir "los rusos somos". Esto marca ya una separación entre ellos y los que se quedaron en su lugar de origen. Esto se tornó evidente cuando preguntamos qué pensaban ellos que los caracterizaba como colombianos: "el darme muy amable con los otros, ¡sí! A respetar a la personas, eso es muy colombiano e irrespetar a la gente, eso es ruso [...] lo ruso sería ser muy honesto en todo, muy honesto, muy, muy verraco, o sea si hay que trasnocharse, sacrificarlo todo por una meta, eso es lo ruso". O como lo ejemplifica Myriam,

uno compara con nuestros países y allá todo es al revés, que es gente muy cruda en comunicación, inclusive cuando yo voy al país primeros días son difíciles para adaptarse a la manera de cómo la gente se relaciona en la calle, en almacenes, siempre da un poco de miedo, ya me acostumbré a Colombia, que es, la gente es muy, muy amable.

Otra relación que encontramos importante en la identificación como colombianos es el hecho de poseer rasgos 
fenotípicos similares. Observamos que quienes tenían características físicas similares a las de los colombianos relataron que en principio pudieron integrarse más fácilmente. Demetrio afirma, "la gente de la parte del este, que hace más calor, son un poquito más morenos, así como yo, yo parezco colombiano $[\ldots]$ por mi aspecto de moreno bajito entonces la gente aquí me recibió como otro colombiano más”. En este sentido, Demetrio decía que toda su familia era igual, exceptuando una hermana que era "como más blanquita”. En contraparte, cabe recordar las palabras de Serger, "yo soy más blanco, mi anatomía es diferente y eso se va a notar". Aunque no es definitivo para la identificación, es claro que las características físicas son usadas como un instrumento de reconocimiento y diferenciación inocultable. Es notable con este caso cómo entran a jugar un papel importante las relaciones entre etnicidad, cuerpo y raza en el estudio de la migración. Según Jackson, "mucha de la construcción social sobre la raza está basada en el cuerpo, que es la superficie primaria de la representación racial". ${ }^{79} \mathrm{Al}$ ser los rasgos físicos de Demetrio y su familia similares a los de la población local -a diferencia de Serger-, esas ideas de las personas de la sociedad receptora sobre los extranjeros que podían prefigurarse desde lo corporal se desdibujaron, las similitudes físicas impedían que sus cuerpos fuesen leídos como extraños, foráneos, y fueran etiquetados como diferentes, al menos

79 Jackson, Ronald. Scripting the Black Masculine Body: Identity, Discourse, and Racial Politics. New York: State University of New York Press, 2006. Impreso. 
durante los primeros contactos o durante las interacciones donde sus identidades soviéticas no fuesen manifiestas.

Otro punto importante que vale la pena mencionar es que hay una correlación entre el ciclo de vida y la identificación. Como habíamos mencionado al principio de este capítulo, la socialización primaria es fundamental en la identidad que generan los sujetos. Las personas que migraron más jóvenes al país tuvieron en general más experiencias significativas relacionadas con su avance entre las etapas del ciclo de vida, como, por ejemplo, formar vínculos afectivos fuertes con amigos, parejas sentimentales, entre otros. Esto se evidencia en que demuestran identidades más fuertes con Colombia que con sus países de origen. Tal como lo expresa Nina, quien migró siendo niña: "Cuando me dicen algo yo digo yo ya soy colombiana porque muchos años, ¡sí! Ya, ya, o sea me siento más extraña allá, acá me siento más normal, porque ya acostumbré. Es que mi vida de adulta casi toda la pasé aquí”. Estos hallazgos soportan la hipótesis presentada por Myers, según la cual la edad en la que se produce la migración es decisiva en la posterior integración como adultos, siendo las edades más tempranas productoras de socializaciones e integraciones más completas. ${ }^{80}$

Los padres que migraron con sus hijos al país cuentan cómo vieron el proceso de estos, describiendo que su principal identidad es como colombianos. Igor asegura, "los niños

80 Myers, Scott. "Childhood Migration and Social Integration in Adulthood". Journal of Marriage and Family 61.3 (1999): 774-789. Internet. 6 nov. 2014. 
acostumbraron, les gustó esta vida, de mucha libertad, allá tenía mucha restricción [...] eso fue un problema muy grave para mí porque yo dedicaba en esta época mucho tiempo para enseñarles, primero español, matemática y les explicaba, pero decían, ¡no nos moleste hay que disfrutar la vida!”. Myriam complementa, "mi hijo ya tiene más vínculo con Colombia, ya no tiene vínculo con Ucrania ni con Rusia, porque ya vive acá, tiene costumbres de los jóvenes de acá, ya es un colombiano". En contraste con los jóvenes, las personas que migraron siendo adultas mantienen marcas y rasgos más prominentes de sus identidades soviéticas, se muestran a sí mismos, por ejemplo, como personas más puntuales, más disciplinadas y estudiosas.

Por último, es necesario comentar la cuestión de la relación de los proyectos de vida de los inmigrantes en Colombia, y particularmente en Bucaramanga y la región santandereana, con el desarrollo de vínculos e identidades colombianas fuertes. Las personas que migraron cuando sus hijos eran aún pequeños, los mismos que plantearon que sus hijos no quieren retornar, sino permanecer acá porque ya son colombianos, proyectan un futuro en el país. Por decirlo de alguna manera, están anclados a la ciudad en gran parte por la fuerza de los vínculos con sus descendientes que desean permanecer en la ciudad. Ante la posibilidad del retorno, la fuerte identidad que sus hijos desarrollaron con el área de recepción y los fuertes vínculos que desarrollaron con personas locales se convierten en obstáculos intervinientes para el retorno de sus progenitores. 
Cuba y Hummon ${ }^{145}$ argumentan que la identificación con los territorios para las personas migrantes tiene que ver en gran medida con su ciclo de vida, como parece ser este caso: "en cuanto los más jóvenes basan sus identidades en las relaciones y afiliaciones personales como las amistades o las relaciones sentimentales, familiares, los migrantes mayores suelen hacerlo a partir de sus experiencias dentro de un determinado lugar"; 81 en este sentido, son evidentes estos dos hechos tanto en el relato de Myriam anteriormente expuesto como en el relato de Verónica que a continuación pasaremos a exponer.

El hecho de proyectarse y tener planes para sus vidas relacionados con el país es puesto en evidencia en expresiones como "sentirse cómodo acá", afirmar que todo lo tienen acá. Esta idea se vio acentuada después del retorno a sus lugares de origen, cuando percibieron que habían cambiado y manifestaron el deseo de no asentarse en allí por preferir a Colombia. Esto es claro en las palabras de Verónica, "mi vida esta acá, ya son 20 años viviendo aquí”, o como lo ilustra Sandra, "no, no, ¡volverse no!, para qué devolverse [...] vamos dejar con el Colombia [vamos a quedarnos], ¡no! Ya tengo casa en el Zapatoca, entonces ya cuando me pensiona, cuando me retira, entonces Sandra cuando va a tener 80 años va para el Zapatoca [risas]”.

81 Cuba, Lee y David Hummon. "Constructing a Sense of Home: Place Affiliation and Migration Across the Life Cycle”. Sociological Forum 8.4 (1993): 547-572. Impreso. 
Lo que es notable en la frase de Sandra es el hecho de que el vínculo con Colombia se expresa como un vínculo con una región, ella no planea trasladarse a un lugar lejano, sino moverse apenas hacia una localidad vecina de la ciudad donde vive. En este sentido podemos entrever que gran parte de la construcción identitaria se da en torno a la apropiación de un territorio, la interiorización de pautas y costumbres está ligada en este caso con la construcción de relaciones afectivas y proyectos de vida asociados a un territorio específico.

Igor señala un hecho importante en cuanto a su identidad y su proyecto de vida, dice, "ahora gano un salario bueno, ahora no quiero regresarme, ahora no quiere regresarse nadie, No, ya no, ya soy colombiano hace un año, colombiano, hace un año me entregaron cédula”. En esta frase corta de Igor, lo que se hace evidente es que la entrega de "los documentos de ciudadanía cumplen una función simbólica, esta función puede ser entendida como un ritual de paso" $\$ 2$ por medio del cual el individuo es reconocido, mediante una ceremonia, en este caso diplomática y jurídica, con otro estatus oficialmente y pasa a pertenecer con reconocimiento del país de acogida, con los mismos derechos y deberes que los locales. Esta ceremonia y su evidencia material, la cédula, entran a jugar un papel muy importante en el autoreconocimiento de los inmigrantes como colombianos y como portadores de una identidad colombiana. Siguiendo la idea de Barth, se

82 Maisonneuve, Jean. Ritos religiosos y civiles. Barcelona: Herder, 1991. Impreso. 
convierten en un nuevo elemento mítico que les sirve para expresar una identidad..$^{83}$

\subsection{7. "Yo soy un ruso con sabor colombiano":}

\section{manutención de identidades y sincretismos}

Una cuestión interesante es el hecho de que algunas de las personas, en su vida diaria, invierten esfuerzos en mantener sus identidades, bien soviética, bien colombiana. Esto parece depender en algún grado del contexto. Por ejemplo, hemos observado que mientras las personas se encontraban en $\mathrm{Co}-$ lombia, realizaban actividades y organizaban prácticas en torno al soporte de sus identidades soviéticas; al contrario, cuando retornaban a sus lugares de origen, manifestaban realizar actividades relacionadas con mantener su identidad colombiana. Estas prácticas sin embargo suelen realizarse en espacios íntimos y personales como los hogares y suelen expresarse en la cotidianidad.

Quizá una de las prácticas más relatadas para mantener las identidades soviéticas se refiera al hecho de intentar preservar la lengua materna. Mantener esta lengua no se limita únicamente al hecho de practicarla para mantener un aspecto de la cultura, sino que es vista como una forma para mantener relaciones simbólicas, en dos niveles. Primero una relación con el país, con lo que representa, y en segundo lugar, para mantener relaciones afectivas con las personas con quienes de alguna manera estuvieron vinculados. Cultivar el lenguaje es una práctica que les permite a los sujetos estar al tanto de

83 Barth, Frederik. "Los grupos”. 
lo que sucede en sus países de origen a nivel económico, político, etc., pues una de sus prácticas más comunes es buscar noticias de sus países en medios que informan en sus lenguas maternas. Igualmente, es el idioma que usan para comunicarse con sus allegados al otro lado del Atlántico y mantener así sus vínculos afectivos personales.

La manutención de las identidades a través de la lengua se hace presente en el vivir diario de los migrantes. Por ejemplo, en la familia Laverde, entre los hermanos y los padres suelen comunicarse en ruso en las situaciones que no involucran personas locales, es decir, cuando entre ellos se comunican por teléfono, se reúnen entre sí o cuando ocasionalmente tienen algún invitado que hable esta lengua: “QQué mantienen de Rusia? [...] Idioma, porque pues igual todos los días hablo con mis hermanas, con mi papá, con mi mamá hablamos en ruso, pues lógicamente es algo que marca la diferencia, todos los dias me recuerda que soy rusa". La anterior es una afirmación de Nina, quien es contundente al presentar este hecho, pero quisiéramos enfatizar la última oración, en la que ella expresa que ese tipo de acciones le recuerdan quién es.

El lenguaje también es un vehículo para la manutención de lazos afectivos, no solo con los familiares y otros soviéticos en la nueva ciudad, sino que sirve igualmente para mantener relaciones con las personas que hacían parte de su red, como familiares y amigos cercanos que se quedaron en su lugar de residencia anterior. El ruso o el ucraniano, bien sea el caso, sirven para comunicarse con las personas en sus zonas de origen. En este sentido, es importante mencionar que las nuevas tecnologías han jugado un papel importante 
al permitir aumentar la frecuencia con que esos lazos son cultivados: el uso de Skype y otras tecnologías para llamar a bajo costo o los correos electrónicos han incitado que las personas hayan aumentado la frecuencia de sus comunicaciones.

El lenguaje sirve también para mantener una relación simbólica y afectiva con el país, con su desarrollo y porvenir, que se expresa mediante comportamientos como buscar información de lo que está sucediendo, procurar noticias e información en general. Estas actividades no se hacen en español, sino en ruso o ucraniano, dependiendo del caso. Nina ilustra esta cuestión diciendo, "siempre me meto, tengo mis periódicos digitales más preferidas a los que yo leo la noticia, tengo estaciones de radio, por ejemplo no escucho radio sino solamente en ruso. Y mis programas favoritos y económicos online son en ruso, entonces todos los días yo los escucho y miro, como digamos, no se pierden los vínculos".

Demetrio, en un sentido similar, aseguró, "leo las cosas más importantes que pasan allá, estoy pendiente de los incendios, me preocupa mucho porque en Rusia el verano aprovechan para sembrar y tener comida todo el año [...] también me gusta leer mucho como de los psicólogos rusos que han hecho cosas bien interesantes".

Lo interesante de este asunto es que se limita el uso de artefactos materiales como objetos para mantener sus identidades. En algunos casos, el uso de objetos emblemáticos y estereotipados de sus culturas de proveniencia, como pueden ser las artesanías, las muñecas rusas y ucranianas (matrioskas 
en ruso y mamushkas en ucraniano), los cuadros de abedul, ${ }^{84}$ entre otros que habíamos comentado anteriormente. Olga añade claramente la idea de que la identificación adquiere también una reminiscencia histórica y de resignificación de los objetos y las tradiciones que la modernidad y la industrialización habían desplazado, lo que se relaciona con lo que Barth afirmaba sobre el distanciamiento con los símbolos que representan la identidad. Esto queda en evidencia en la siguiente frase de Olga: "Normalmente allá en las casas no hay esas matrioskas, esas no sé qué cosas más como folclóricas, tradicionales, porque son más del pasado [...] esos vestidos de punto de cruz con ornamentos tradicionales". Continúa su relato diciendo, "esas son cosas de abuelita [...] pero cuando uno llega aquí, claro ya eres ruso o ucraniano, o sea ya eres diferente, entonces uno trata de tener en la casa algo que lo distingue como ucraniano, entonces yo traje matrioska $[. .$.$] con imágenes ucranianas”.$

El hijo de Myriam le increpaba por no tener nada, Myriam decía, "en la casa no tenemos nada de Rusia, sí, entonces ya tengo matrioskas y ya tengo platicos de Rusia colgados en la pared, sí, alguito”.

Una última estrategia que hemos encontrado para mantener su identidad soviética se relaciona con la sustitución, es decir, tomar elementos disponibles en el área de llegada e intentar emular los elementos existentes en sus áreas de origen, esto es en cierta forma un modo de suplir la ausencia

84 Los trabajos realizados con la corteza del abedul hacen parte importante de la cultura material rusa, varias artesanías son elaboradas con dicho material. 
de elementos propios de la cultura material. Esto se ve muy claro en la alimentación. Lo que todos tienden a aseverar es que intentan preservar sus formas de alimentación tradicionales y que debido a la difícil obtención de ciertos alimentos, usan ingredientes locales como sustitutos. Por ejemplo, Nina dice, "pues la mayoría se consigue y si no se consigue algo tú lo puedes cambiar [...] Puedes hacer como esos cambios, pues de pronto te piden un pescado, pones otro pescado o algo, pero en general se puede hacer, ¡sí!”

Tania lo refiere así, “ahora en el Éxito de Bogotá se están haciendo un pan parecido al ruso, pan de cebada, es marroncito, así redondito, ¡ahí tienen que probarlo! [...] mi hermana que vive en Bogotá ya las descubrió, entonces va allá y compra pan, ¡casi idéntico ruso lo están haciendo! [...] por lo delicioso que es".

O en otros casos, cuando existe la posibilidad encargan a las personas que viajan de traer viandas, "yo le pedí a papá que me trajera té $[\ldots]$ y un grano como tipo arroz que se llama 'greishka', pero que no se consigue acá”. De la misma forma que una identidad soviética es mantenida, los sujetos realizan acciones tendientes a mantener sus nuevas identidades colombianas. Estas estrategias emergen en el contexto del retorno. Como bien lo dice Lina, "esa carne oreada de Santander me parece muy rica [...] en Rusia, yo cuando estudiaba, yo hasta conseguía harina esa de maíz, que allá eso no se vendía, la conseguía con los georgianos [...] hacía arepas".

Stryker explica que "las identidades internalizadas por los individuos se encuentran ordenadas dentro de una 
jerarquía” ${ }^{85}$ Sin embargo, esta jerarquización no siempre es clara y libre de controversia, por momentos puede observarse a las identidades coexistiendo armoniosamente y en otras ocasiones compitiendo. Una diferenciación clara la encontramos con el ciclo de vida: aquellos que llegaron más pequeños suelen ordenar su identidad colombiana por encima de su identidad soviética, mientras quienes llegaron ya siendo adultos parecen ordenarlas al contrario.

De igual manera, Stryker indica que las identidades tienen una notabilidad situacional, esto es, que las identidades emergen en contextos particulares, y algunas son muy limitadas a contextos muy específicos. ${ }^{86}$ Por ejemplo, están las identidades grupales, que sólo emergen cuando se está dentro de ese grupo específico; al contrario de este tipo de identidades, las identidades nacionales son transituacionales, es decir que son transversales a muchos aspectos y se presentan en múltiples situaciones, desde las cotidianas hasta las extraordinarias. ${ }^{87}$ Lo que observamos es que en ocasiones se forman sincretismos, momentos en que las identidades tienden al amalgamamiento y se presentan en la vida diaria conjuntamente.

Esto es una realidad patente para los individuos, por ejemplo, Demetrio contaba cómo sus identidades nacionales se alternaban y eran percibidas tanto por él como por sus significantes. Él afirmaba: "soy colombiano, me gusta

\footnotetext{
${ }^{85}$ Stryker, Sheldon y Peter Burke. "The Past".

86 Ibid.

87 Barth, Frederik. “Los grupos”.
} 
hacer cosas de colombianos, me identifico con cosas como 'bailar', cosa que en Rusia no se acostumbraba a hacer con la frecuencia que se hace en Colombia, pero al mismo me delata que soy ruso porque como cosas raras, cocino cosas raras $[\ldots]$ y porque conocen a mi papá”.

En las prácticas cotidianas estos sincretismos son verídicos. Varios entrevistados contaron que habían desarrollado una forma híbrida de lenguaje, por ejemplo Nina señalaba: "esas palabras nuevas que la raíz de la palabra en ruso, ah, no, perdón, la raíz de la palabra en español pero la terminación en ruso, y conjugamos como si fuera en ruso y así hablamos a veces con teléfono con mi hermano, ahí, y me dice, ¿pero que me está diciendo? No te entiendo".

Por su parte, Tania decía: "hay familias que por ejemplo mamá dice al niño en ruso y él le responde en español, es que entiende, no es que no entienda, solo que no tienen suficiente vocabulario para expresarse y nosotros también mezclamos, a veces es más fácil encontrar una palabra en español que en ruso, pensando, no, mejor en español, la mitad en ruso, una mezcla”.

Demetrio por su parte narra: "pues con hermanos ya es mezclado, español con ruso ¡no! mucho, mezclamos mucho ¡no!”

Estos sincretismos también se observan en algunos hogares donde es común encontrar objetos típicos colombianos al lado de artesanías rusas, al igual que es común encontrar en algunas bibliotecas libros en ruso al lado de libros en español. En su entorno conviven dos culturas y dos identidades que en algunos se hacen evidentes en su vida cotidiana. 
Es común ver cómo después de realizar prácticas típicas colombianas como ir a bailar salsa, llegan a sus casas a hacer cosas típicas rusas, tal como lo refiere Demetrio: "Pues yo soy un joven normal colombiano sí, salgo a rumbear como todos, lo único es que al volver hago mis ensaladas y sopas rusas con mi papá”.

Como conclusión preliminar, podríamos decir que aunque no están libres de conflicto, estas dos identidades no están en disputa, de hecho en la cotidianidad conviven de manera relativamente armónica, no solamente porque diariamente se recrean prácticas, comportamientos y actitudes que refuerzan tanto a la identidad colombiana como a la soviética, sino porque hay un interés de las personas por mantenerlas. Sin embargo, es notable un leve grado de aculturación, pues hasta cierto punto estos procesos vividos por los inmigrantes que terminaron con la adquisición de una nueva cultura, la del país que los acogió, tuvieron un precio, consistente en renunciar al menos a una parte de la cultura de la cual venían y en la cual inicialmente fueron criados. Tal vez la frase que mejor resume este punto, y que de hecho hemos usado para titular esta sección, es "yo soy un ruso con sabor colombiano". 



\section{Conclusiones}

Para finalizar, deseamos cerrar este trabajo presentando las que son quizá algunas de las más importantes y relevantes ideas resultantes. Antes de proseguir, ratificamos que los alcances de esta investigación se vieron influenciados por el hecho de que es el primer estudio monográfico dedicado a comprender los procesos migratorios de los ciudadanos de algunas de las ex repúblicas soviéticas. Por tanto, esta investigación no se centró en profundizar algún momento del proceso como tal, sino en mostrar una visión panorámica del mismo. Esto es, sentar las bases para futuras investigaciones en las que se profundicen algunos de esos momentos. Adicionalmente, observar el proceso migratorio como un continuum nos permitió a lo largo de este documento apreciar la migración como un fenómeno que es a la vez estructural e individual, acercándonos a un paradigma integrado del holismo y el individualismo, igualmente concordante con investigaciones panorámicas, ya que amplían el espectro de lo que puede llegar a conocerse en principio, y son puntos seminales para el estudio posterior de hechos particulares.

Para iniciar, quisiéramos comentar que en lo referente a la metodología, debemos mencionar un hecho que es de la mayor relevancia para el estudio de las migraciones. Aunque las historias de vida han sido la técnica más emblemática en 
estos estudios desde que fue usada de manera intensiva en el seno de la Escuela de Chicago, lejos de ser una técnica desactualizada, hoy en día evidencia ser de gran utilidad. Fue un método pertinente en este caso de estudio, no solo por el hecho de que nos permitió tener una visión real del proceso y de las diferentes etapas de la migración, sino porque también es claro que esta técnica puede nutrirse y aunarse a las nuevas tecnologías de la comunicación que están disponibles. Solo por citar un ejemplo, con el uso de plataformas online de Social Media como Facebook, donde estas personas guardaban apartados de su ceremonia de entrega de documentos que los acreditaban como ciudadanos colombianos. Esto abre la posibilidad, de repente, de estudiar las representaciones sobre la migración hechas por los migrantes mismos en el plano digital, tema que queda abierto para estudios posteriores, que infelizmente en este trabajo no consideramos. Aun así, creemos que tiene un amplio potencial en el estudio en general de la migración.

Tal vez lo segundo que resulta evidente en este estudio es que aunque no existen muchas inmigraciones de gran magnitud en Colombia, y aunque no hayan sido tomadas en cuenta en la agenda académica, resulta importante su estudio, pues, como mostramos desde el primer capítulo, estas han implicado cambios profundos en las regiones donde se han asentado, aportando desarrollo y progreso. Prueba de ello es el asentamiento de inmigrantes desde el siglo XIX en el país y en la región santandereana, que trajeron avances y desarrollo, y, más recientemente, la llegada de soviéticos que han logrado insertarse en esferas académicas y artísticas, 
logrando permear distintos ambientes de la sociedad, ayudando al avance artístico y científico de la región. Esto es en cierto sentido una apología de los estudios de caso, pues, si bien sus alcances no son tan grandes ni visibilizados, son importantes, no solo para entender la historia de las regiones, sino el futuro de estas.

En tercer lugar, debemos referirnos al hecho de que este estudio difiere de la corriente principal de los estudios sobre las migraciones. En nuestro caso, no se trata de sujetos que llegan en condiciones marginales, ni estigmatizados por la sociedad receptora. Esto parece deberse a que, como observamos también históricamente, quienes llegan con mayor capital económico o cultural tienen mayor probabilidad de insertase exitosamente y de ocupar espacios sociales más altos. Esta condición les permite ser bien reconocidos dentro de la sociedad receptora, a diferencia de inmigrantes con menor capital cultural y económico. Este hecho comprueba la hipótesis planteada al principio de este trabajo, a decir: la alta cualificación de estos sujetos les permitió una integración menos traumática y en esferas altas de la sociedad receptora, sin pasar por procesos de marginación.

Sin embargo, aunque es evidente que la inmigración de personas altamente calificadas ha tenido un impacto importante en términos cualitativos en la región, también es evidente que quizá por la magnitud relativamente baja de la misma, esta no ha causado cambios profundos en la estructura social; visto de otra manera, ha sido mayor la capacidad de la sociedad para integrar a los migrantes que la capacidad de los migrantes para modificarla. 
Ahora, si nos remitimos a las preguntas que enunciamos como guías de esta investigación, podemos resaltar varias cuestiones. En cuanto a nuestra primera interrogante, que vale la pena recordar -¿por qué llegaron estos extranjeros a Colombia y se asentaron en Bucaramanga?-, podemos concluir que esta migración no se explica por un solo factor. Por el contrario, reafirmamos que para entender las migraciones de estos sujetos es necesaria una aproximación multicausal, y no solo eso, también es necesario buscar esas causas en diferentes niveles, desde lo estructural hasta lo individual. No fue solamente la acuciosa situación política, económica y social que afrontaban las naciones soviéticas para la época de la perestroika y posperestroika las que impulsaron la migración, sino que, además, el capital social de los individuos, que se expresa en la conformación de vínculos y en las relaciones entre sujetos, son necesarias para comprender por qué se produjo la movilización. Además, el hecho de detentar un alto capital cultural facilitó que estos migrantes tuvieran ofertas laborales concretas antes de su migración, lo que en últimas logró la materialización de sus proyectos migratorios.

Es evidente el hecho de que en la decisión de migrar algunos factores pesaron más que otros, pero esto es particular a los procesos migratorios de cada uno de los individuos. En algunos casos fue más importante el papel de los lazos débiles dentro de la red, y en otros la función que desempeñaron los vínculos fuertes al presentar a Colombia como destino. Además, resulta evidente cómo en el caso de matrimonios entre ciudadanos colombianos y rusos, el factor principal 
para escoger Colombia se debió al vínculo que se generaba con una persona del país, mientras que para las personas que llegaron gracias a la información de un lazo débil, su motivación se basó en propuestas laborales concretas.

Por otra parte, aunque todas las migraciones en estos casos se dieron bajo el contexto de la crisis que enfrentaban los países soviéticos, hay que tener en cuenta que los factores decisivos para migrar estuvieron directamente relacionados con el rol que ocupaban los individuos en el hogar. Para Sandra, madre de cuatro hijos, por ejemplo, uno de los factores importantes que motivaron su migración fue la llegada de nuevos productos, costumbres y el nuevo estilo de vida que comenzaban a vivir los jóvenes, que a su juicio eran inaceptables y ponían en cuestión los valores básicos de su sociedad y de sus familias. Para Igor, sustento económico de su familia, por otra parte, un factor importante en su decisión de migrar fue la difícil situación económica que atravesaban los países soviéticos durante la posperestroika.

Sin embargo, aunque aceptamos la multicausalidad para explicar la migración de estos sujetos, es importante aclarar que este estudio de caso transgrede la idea de que las migraciones se dan por flujos bien definidos y rutas previamente establecidas. En este caso no existían muchos ciudadanos de estas nacionalidades previamente en el país, de hecho, la ruta desde sus países a Colombia era inexistente. Por tanto, los proyectos de migración no se concretaron por la existencia de redes en el país de origen, sino que se debieron más a vínculos fuertes con colombianos, a propuestas concretas de trabajo y a la previa migración de colombianos a estas naciones. 
El hecho de que no existiera una migración previa de personas provenientes de la ex URss se explica en parte por la coyuntura sociopolítica que restringía la movilización internacional. Adicionalmente, el hecho de que no se conformara una comunidad puede correlacionarse con que la migración no se haya sostenido en el tiempo. Esto, porque no existen redes de solidaridad extensas y constituidas en el lugar de destino para institucionalizar estos flujos migratorios y darles un carácter duradero. Es de considerar el hecho de que después de la gran depresión y la crisis que sobrevino a la caída de la URss, las naciones postsoviéticas de Rusia y Ucrania, de donde provenían nuestros investigados, han mostrado una recuperación económica rápida y sostenida.

También es importante recalcar que aunque en la teoría de las migraciones no se ha tomado mucho en cuenta la fuerza de los lazos débiles, estos son muy importantes en el proceso migratorio, pues fueron los que posibilitaron que algunos inmigrantes, en ese entonces prospectivos, contemplaran a Colombia como un posible destino para vincularse al mercado laboral. Además, en la socialización también entran a ocupar un papel fundamental, pues son los alumnos y los compañeros de trabajo, entre otros, los que ayudan a estos sujetos a entender el nuevo entorno, y no solamente sus amigos o parejas con quienes tienen vínculos más fuertes. Además, esta imagen sería estática, pues descarta la posibilidad de que vínculos fuertes se tornen débiles y al contrario, como es el caso de las mujeres que posteriormente dejan de comunicarse con sus paisanos o que se separan de sus esposos. En estos casos, los vínculos fuertes pasan a ser débiles, 
pero se continúa el aprendizaje gracias a los compañeros de trabajo y nuevos amigos. Adicionalmente, hay que controvertir que únicamente los lazos débiles funcionen como puentes, sobre todo en el caso de las migraciones, pues en las uniones mixtas observamos que un vínculo fuerte entre dos sujetos de diferentes regiones puede conectar redes completamente diferentes en sus respectivas áreas de origen y llevar información nueva a redes muy densas.

En cuanto al proceso de integración a la ciudad, pudimos ver cómo en la interacción con otros los sujetos aprenden las nuevas prácticas y reglas. Sin embargo, este proceso no concluye hasta que además de entenderlas las interioricen y las toleren. Además, en este punto hay que anotar que las dificultades son latentes. Como la socialización no es un modelo lineal, los problemas, que se presentan de manera más marcada en los días apenas posteriores a su arribo, se mantienen constantes en todo el proceso de integración.

Hay que tener en cuenta en este punto que el capital cultural que detentaban los sujetos facilitó la rápida inserción de estos en el mundo laboral, en cargos acordes a su capacidad, y que el hecho de que su capital cultural estuviera por encima del de los nativos suprimía la etapa de conflicto con ellos por adquirir un espacio en el mercado laboral. Por el contrario, era percibido en la observación cómo los nativos veían con buenos ojos la llegada de estos inmigrantes, a los que consideraban personas muy inteligentes y trabajadoras. Por otro lado, el alto capital cultural que detentaban les facilitó su relación con los locales. Todo esto culminó en una exitosa integración, a diferencia de otras comunidades de 
migrantes que llegan con estatus muy bajos y ocupan labores estigmatizadas.

Para concluir, entre las temáticas que dejamos abiertas para profundizar en próximas investigaciones, encontramos cuatro temas principales que consideramos podrían ser estudiados a cabalidad. Primero, el papel de los documentos legales en la formación de la identidad, donde es válido examinar los rituales asociados a la migración en los cuales los objetos legales juegan roles simbólicos importantes. En este sentido podrían estudiarse -no sólo con ciudadanos de las repúblicas ex soviéticas- ritos asociados a la obtención de pasaportes, tiquetes aéreos, estatus como refugiados, etc. El segundo punto que dejamos abierto para profundizar es la razón de la inexistencia de una comunidad consolidada en la ciudad receptora. Se podrían explorar más a fondo las relaciones particulares que tienen los individuos entre sí y las dinámicas de las redes compuestas por ciudadanos soviéticos, desde su formación hasta el presente.

En tercer lugar, sería pertinente examinar con mayor detenimiento las razones que explican el retorno de estos sujetos a sus países de origen, lo cual constituye una oportunidad para poner a prueba la idea sugerida aquí de que la construcción de fuertes vínculos con personas del país o la ciudad receptora funcionan como anclas, que desestimulan los movimientos de retorno. Igualmente, sería muy interesante estudiar cómo son los procesos de reintegración de las personas que vivieron periodos prolongados en Colombia y deciden retornar a sus países. En cuarto y último lugar, que$\mathrm{da}$ abierto el espacio para hacer estudios comparativos con 
otros grupos de migrantes en la ciudad que han llegado con menor capital social, económico y cultural, centrándose en sus procesos de integración, lo que ayudaría a comprobar la tesis de que dependiendo del capital económico, social y cultural que detenten los sujetos al llegar es que logran integrarse de forma satisfactoria y en posiciones favorables en la sociedad que los recibe.

Para finalizar, debemos reiterar la idea de que la migración es un fenómeno complejo y extenso, lo cual lo torna un objeto de investigación desafiante. Gracias a esta característi$\mathrm{ca}$, puede ser evaluado desde diversas posturas teóricas, que pueden contribuir a desentrañar aspectos y matices diversos que hacen de cada movilización y cada etapa dentro de ese proceso un universo particular en sí, a ser descubierto, que requiere y exige abordajes profundos y variados para su compresión y explicación. 



\section{Referencias}

Achen, Christopher. "Parental Socialization and Rational Party Identification”. Political Behavior, Special Issue: Parties and Partisanship 24.2 (2002): 151-170. Impreso.

Amorós, Celia. "Crítica de la identidad pura”. Debats, Institució Alfons el Magnamim 89 (2005): 62-72. Impreso.

Balán, Jorge. Las Historias de Vida en Ciencias Sociales: Teoría y Técnica. Buenos Aires: Editorial Nueva Visión, 1974. Impreso.

Banks, Marcus. Visual Methods in Social Research. Gran Bretaña: SAGE, 2001. Impreso.

Barth, Frederik. Los grupos étnicos y sus fronteras. México D. F.: Fondo de Cultura Económica, 1976. Impreso.

Becker, Howard. Historias de Vida en Sociología. Citado en Balán, Jorge. Las Historias de Vida en Ciencias Sociales: Teoría y Técnica. Buenos Aires: Editorial Nueva Visión, 1974. 27-30. Impreso.

Berger, Peter y Thomas Luckmann. La construcción social de la realidad. Buenos Aires: Amorrortu, 1986. Impreso.

Bourdieu, Pierre. "La identidad y la representación: elementos para una reflexión crítica sobre la idea de región (análisis)". Ecuador Debate 67 (2006): 165-184. Impreso.

Bourdieu, Pierre. Capital cultural, escuela y espacio social. Madrid: Siglo XXI Editores, 1997. Impreso. 
Bourdieu, Pierre. "Le capital social, notes provisoires”. En Bevort A. y M. Lallement. Le Capital social. Performance, équité et réciprocité. París: La Découverte, 2006. 29-34. Impreso. Bourdieu, Pierre. "El espacio social y la génesis de las 'clases"”. Estudios sobre las Culturas Contemporáneas III.7 (1989): 281-309. Impreso.

Burgess, Ernest y Robert Park. "Cultural Conflict and the Marginal Man”. Introduction to the Science of Sociology. Chicago: The University of Chicago Press, 1921. Impreso.

Cárdenas, Mauricio y Carolina Mejía. "Migraciones internacionales en Colombia: ¿Qué sabemos?”. Working Paper Series 30 (2006): 27-30. Impreso.

Castells, Manuel. The Rise of the Network Society: The Information Age, Economy, Society and Culture. New York: Willey-Blackwell, 2009. Impreso.

Castells, Manuel. La ciudad y las masas. Sociología de los movimientos sociales urbanos. Madrid: Alianza, 1986. Impreso. Coleman, James. "Social capital in the creation of human capital”, The American Journal of Sociology 94, Supplement: Organizations and Institutions: Sociological and Economic Approaches to the Analysis of Social Structure, (1988): 95-120. Impreso.

Colombia, Departamento Nacional de Estadística. Aproximación a la migración internacional en Colombia a partir del censo general 2005. Bogotá: DANE, 2006. Impreso.

Colombia, Departamento Nacional de Estadística. Reporte censo general 1993. Bogotá: DANE, 2004. Impreso.

Colombia, Departamento Nacional de Estadística. Censo General 2005. Bogotá: DANE. 2007. Impreso. 
Cooley, Charles. Human Nature and the Social Order. Illinois: The Free Press, 1956. Impreso.

Cuba, Lee y David Hummon. "Constructing a Sense of Home: Place Affiliation and Migration Across the Life Cycle". Sociological Forum 8.4 (1993): 547-572. Impreso.

Dubet, François. De la sociología de la identidad a la sociología del sujeto. Toulouse: Estudios Sociológicos, 1989. Impreso.

Durand, Gilbert. La imaginación simbólica. España: Amorrortu editores, 2007. Impreso.

Durkheim, Emile. El suicidio. Lima: Editorial Losada, 2004. Impreso.

Elfrente.com.co. Cano perdió la guerra. 2010. Internet. 5 nov. 2011.

Eyles, John y Walter Peace. "Signs and Symbols in Hamilton: An Iconology of Steeltown”. Geografiska Annaler 72.2 (1990): 73-88. Impreso.

Froman, Lewis. "Personality and Political Socialization". The Journal of Politics, Cambridge University Press on Behalf of the Southern Political Science Association 23.2 (1961): 341-352. Impreso.

García Canclini, Néstor. Imaginarios Urbanos. Buenos Aires: Editorial Eudeba, 1997. Impreso.

García, Rodrigo. Los extranjeros en Colombia. Bogotá: Editorial Planeta Colombia, 2006. Impreso.

Gardner, Katy. Age, Narrative and Migration: The Life Course and Life Histories of Bengali Elders in London. Oxford: Berg, 2002. Impreso. 
Giménez, Gilberto. Identidades Sociales. México D. F.: Conaculta/Instituto Mexiquense de Cultura, 2009. Impreso.

Gordon, Sara y René Millán. “Capital social: una lectura de tres perspectivas clásicas”. Revista Mexicana de Sociología 4 (2004): 711-747. Internet. 5 nov. 2014.

Granovetter, Mark. "The Strength of Weak Ties”. American Journal of Sociology 78.6 (1973): 1360-1380. Impreso.

Hall, Edward. The Hidden Dimension. New York: Anchor Books Doubleday, 1990. Impreso.

Harker, Roberto. Bucaramanga: Los inmigrantes y el progreso, 1942-1992. Bucaramanga: Alcaldía de Bucaramanga, 1992. Impreso.

Harker, Roberto. Sucedió en Bucaramanga. Bucaramanga: Academia de Historia de Santander, 1977. Impreso.

Hernández, José Angel. “Emigración Judía en Colombia en los Años 1930 y 1940. Un Caso Particular: los Polacos”. Revista Pensamiento y Cultura 10 (2007): 177-190. Impreso. Hess, Beth, et al. Sociology. New York: Macmillan Pub Co, 1995. Impreso.

Hodkinson, Paul. Goth: Identity, Style, and Subculture. Oxford: Berg, 2002. Impreso.

Jackson, Ronald. Scripting the Black Masculine Body: Identity, Discourse, and Racial Politics. New York: State University of New York Press, 2006. Impreso.

Kon, Igor. "Identity Crisis and Postcommunist Psychology". Symbolic Interaction 16.4 (1993): 395-405. Impreso.

Kopnina, Helen. East to West Migration: Russian Migrants in Western Europe. Aldershot: Ashgate Publishing, 2005. Impreso. 
Lee, Everett. “A Theory of Migration”. Demography 3.1 (1966): 47-57. Internet. 4 nov. 2014.

Lorimer, Frank. The Population of the Soviet Union: History and Prospects. Geneva: League of Nations, 1946. Impreso. Lovell, Stephen. The Soviet Union: a Very Short Introduction. Oxford: Oxford University Press, 2009. Impreso.

Maisonneuve, Jean. Ritos religiosos y civiles. Barcelona: Herder, 1991. Impreso.

Marsvati, Amir. Qualitative Research in Sociology: An Introduction. Gran Bretaña: SAGE, 2004. Impreso.

Martínez, Frédéric. “Apogeo y decadencia del ideal de la inmigración europea en Colombia, siglo xIX”. Trad. Ximena Fidalgo. Boletín cultural y Bibliográfico 34.44 (1997): 3-45. Impreso.

Martínez, Jorge. El mapa migratorio de América Latina y el Caribe, las mujeres y el género. Santiago de Chile: Celade, 2003. Impreso.

Mead, George. Mind Self and Society from the Standpoint of a Social Behaviorist. Ed. Charles W. Morris. Chicago: University of Chicago, 1934. Impreso.

Mejía, Adolfo. México y la Unión Soviética en la defensa de la paz. México D. F.: Agencia de prensa Nósvoti, 1986. Impreso.

Melucci, Alberto. Acción Colectiva, Vida Cotidiana y Democracia. México D. F.: Colegio de México, 1999. Impreso. Myers, Scott. "Childhood Migration and Social Integration in Adulthood". Journal of Marriage and Family 61.3 (1999): 774-789. Internet. 6 nov. 2014. 
Park, Robert. "Mentality of Racial Hybrids". The American Journal of Sociology 36.4 (1931): 534-551. Impreso.

Park, Robert. "Racial Assimilation in Secondary Groups with Particular Reference to the Negro". American Journal of Sociology 24.2 (1914): 151-170. Impreso.

Pilkington, Hilary. Migration, Displacement, and Identity in Post-Soviet Russia. London: Routledge, 1998. Impreso. Portes, Alejandro. "Contemporary Immigration: Theoretical Perspective on Its Determinants and Modes of Incorporation". The International Migration Review 23.3 (1989): 606-630. Impreso.

Putnam, Robert. Democracies in Flux: The Evolution of Social Capital in Contemporary Society. New York: Oxford University Press, 2004. Impreso.

Radnitz, Scott. "What Really Happened in Kyrgyzstan?”. Journal of Democracy 17.2 (2006):132-146. Impreso.

Raijman, Rebeca, et al. "International Migration, Domestic Work and Care Work: Undocumented Latina Migrants in Israel”. Gender E Society 17.5 (2003): 727-749. Impreso. Remennick, Larissa. Russian Jews on Three Continents: Identity, Integration, and Conflict. New Brunswick: Transaction Publishers, 2007. Impreso.

Resendiz, Ramón. "Biografía: proceso y nudos teórico-metodológicos". Observar, escuchar y comprender. Sobre la tradición cualitativa en la investigación social. Ed. María Luisa Tarrés. México: FLACso, 2001. 135-169. Impreso. Rodríguez, Horacio. Migración alemana al Estado Soberano de Santander en el siglo XIX: repercusiones socioeconómicas 
de un proceso de transculturación. Bucaramanga: Editorial Kelly, 1968. Impreso.

Rusia, Embajada de la Federación de Rusia en la República de

Colombia. Relaciones ruso-colombianas: una ojeada a la

bistoria. Internet. 6 nov. 2014.

Sanmiguel, Inés. "Japoneses en Colombia. Historia de inmigración, sus descendientes en Japón”. Revista de Estudios Sociales 23 (2006): 81-96. Impreso.

Shevtsova, Lilia. "Postsoviet Emigration Today and Tomorrow". International Migration Review 26.2 (1992): 241-260. Impreso.

Soto, Carlos. Condición de los extranjeros en Colombia. Bogotá: Editorial Posse, 1930. Impreso.

Spradley, James. Participant Observation. New York: Holt, Rinehart and Winston, 1980. Impreso.

Stryker, Sheldon y Peter Burke. "The Past, Present, and Future of an Identity Theory”. Social Psychology Quarterly Special Millenium Issue on the State of Sociological Social Psychology. American Sociological Association (2000): 284-297. Impreso.

Stryker, Sheldon y Richard Serpe. "Identity Salience and Psychological Centrality: Equivalent, Overlapping, or Complementary Concepts?”. Social Psychology Quarter 57.1 (1994): 16-35. Impreso.

Tajfel, Henri, et al. "The Social Identity Theory of Intergroup Behavior. Political Psychology: Key Readings”. Political Psychology: Key Readings, Key Readings in Social Psychology. New York: us Psychology Press, 2004. 276293. Impreso. 
Tajfel, Henri. Grupos Humanos y Categorías Sociales: Estudios de Psicología Social. Trad. Carmen Huici. Barcelona: Herder, 1984. Impreso.

Tebbakh, Sonia. "Political Identities of the Population of North-African Descent in France”. Science PO Grenoble, Paper presented at the Joint Sessions of Workshops, workshop 14 "Political Participation of Immigrants and Their Descendants in Post-War Western Europe”, 2010. Impreso.

Thompson, John. Russia and the Soviet Union: A Historical Introduction from The Kievan State to the Present. London: Westview Press Inc., 2008. Impreso.

Tishkov, Valery. Ethnicity, Nationalism and Conflict in and after the Soviet: the Mind Aflame. London: Sage Publications, 1997. Impreso.

Tobin, Joseph, et al. Preschool in Three Cultures: Japan, China and the United States. New York: Yale University Press, 1991. 284-297. Impreso.

Touraine, Alain. "Los movimientos sociales". Revista colombiana de Sociología 27 (2006): 255-278. Impreso.

Valcárcel, Marcel. Aspectos teóricos del Capital Social y elementos para su uso en el análisis de la realidad. Lima: Universidad Católica del Perú, 2008. Impreso.

Vargas, Pilar, et al. Los árabes en Colombia. Del rechazo a la integración. Bogotá: Ed. Planeta, 1991. Impreso.

Värnik, Andrei. "Suicide in Estonia". Acta Psychiatrica Scandinavica 84.3 (2007): 229-232. Impreso. 
Velasco, Laura y Óscar Contreras. "Raza, clase y etnicidad: un acercamiento a la sociología de John Rex". Revista Mexicana de Sociología 68.1 (2006): 81-102. Impreso.

Villa, Miguel y Jorge Martínez. El mapa migratorio internacional de América Latina y el Caribe: patrones, perfiles, repercusiones e incertidumbres. Santiago de Chile: Celade, 2001. Impreso.

Villa, Miguel y Jorge Martínez. Tendencias y patrones de la migración internacional en América latina y el Caribe. Santiago de Chile: Cepal/Celade, 2001. Impreso.

White, Stephen, et al. "The Political Resocialization of Immigrants: Resistance or Lifelong Learning?”. Political Research Quarterly 61.2 (2008): 268- 281. Impreso.

Young, Pauline. "The Russian Molokans in Los Angeles". American Journal of Sociology 35(1929): 393-402. Impreso. 
Este libro fue compuesto en caracteres

Stempel Garamond 12 puntos, sobre papel propal de 70 gramos y encuadernado con método Hot Melt, en abril de 2015, en Bogotá, D. C., Colombia 